\title{
The Royal College of Physicians and Surgeons of Canada 2007 Annual Conference
}

Le Collège Royal des Médecins et Chirurgiens du Canada Conférence Annuelle 2007

Crossroads: The future of specialty medicine and medical education amid evolving healthcare
À la croisée des chemins : l'avenir de la médecine spécialisée et de l'éducation médicale dans le système de santé en mutation

\section{Winnipeg, Manitoba}

September 27th-29th, 2007

du 27 au 29 Septembre, 2007

Abstracts / Résumés 


\section{TABLE OF CONTENTS}

CONCURRENT SESSIONS. 13

CONCURRENT SESSIONS ABSTRACTS - RÉSUMÉS DES

SESSIONS CONCOMITANTES. 13

SIGN-UP SESSION \#113

Health systems change through learning collaboratives: Multidisciplinary partnerships in paediatric health care

J. Houbé, M. Inkelas, M. O'Donnell.,University of

British Columbia, Vancouver, BC, University of

California-Los Angeles School of Public Health, Los

Angeles, $C A$.

SIGN-UP SESSION \#114

Challenges of surgical specialties: Beyond corporatism.

S. Dubé, G. Beauchamp, P. Bourgouin, J. Dubois, $R$.

Ghali, B. Montreuil, L. Valiquette. University of

Montréal, Montréal, Qué.

SIGN-UP SESSION \#115

The art of setting learning objectives

G. Bandiera, N. Tenn-Lyn. University of Toronto,

University Health Network, Toronto, Ont.

SIGN-UP SESSION \#116

Collaboration between family physicans and other specialists: How can we teach this?

L. Nasmith. S. Dojeiji. University of British Columbia,

Vancouver, BC, University of Ottawa, Ottawa, Ont.

\section{SIGN-UP SESSION \#117}

Learning on the Run: Practical tools to enhance self-directed learning in practice

C. Campbell, R. Bankey. The Royal College of

Physicians and Surgeons of Canada, Ottawa, Ont.

\section{SIGN-UP SESSION \#118}

Panel discussion: The many faces of health human resources planning.

P. Shrichand, D. Fréchette. The Royal College of

Physicians and Surgeons of Canada, Ottawa, Ont.

\section{SYMPOSIUM \#119}

Clinician investigators: Pathway to future success B. Winston. University of Calgary, Calgary, Alta.

SIGN-UP SESSION \#120

Slowing down when you should: A new model of intra-operative judgment and its implications for teaching.

C-A. Moulton, G. Regehr, H. MacRae. University of

Toronto, Department of Surgery, Toronto, Ont.

SIGN-UP SESSION \#121

When a community hospital becomes an academic centre

M. Topps, M. Wilson, W. McCready, K. Ferris,

Northern Ontario School of Medicine, Sudbury, Ont.

SIGN-UP SESSION \#122

The CanMEDS Communicator role in the 'real world': Taking Communication skills teaching to the bedside

L.J. Cooke, S. Dojeiji. University of Calgary, Calgary, Alta., University of Ottawa, Ottawa, Ont.

SIGN-UP SESSION \#123

How to build a physician health curriculum for your residency program

D. Puddester, J. Cohen, L. Flynn. University of Ottawa,

Ottawa, Ont., University of Calgary, Calgary, Alta., Queen's University, Kingston, Ont.

SIGN-UP SESSION \#124

Medical education and health technology assessment: Creating partnerships to address the CanMEDS roles of manager and health advocate M. Allen, D. Sinclair, D. Juzwishin, D. Husereau. Dalhousie University, Halifax, NS, Juzwishin Consulting Inc., St. Albert, Alta., Canadian Agency for Drugs and Technology in Health, Ottawa, Ont.

SIGN-UP SESSION \#125

Continuing education for collaborative mental health care: An interprofessional education, elearning approach

E. Pauzé, F. Lemire, V. Curran, T. Ungar. College of Family Physicians of Canada, Mississauga, Ont., Memorial University, St. John's, NL, North York General Hospital, Toronto, Ont. 


\section{SIGN-UP SESSION \#126}

Facilitating multi-source feedback for selfassessment and practice improvement J. Sargeant. Dalhousie University, Halifax, NS.

SYMPOSIUM \#127

Medical specialization - the good, the bad and the inevitable

D. Gilchrist, C.P.W. Warren, G. Weisz. University of Alberta, Edmonton, Alta., University of Manitoba,

Winnipeg, Man., McGill University, Montréal, Qué.

SIGN-UP SESSION \#128

The impact of patient- and family-centered care on medical care and specialty medicine: Education Effective communications and models of care W. Moore, V. Robinson, M. Williams, M. Cliatt. Medical College of Georgia, Center for Patient and Family Centered Care, Augusta, GA.

SIGN-UP SESSION \#129

A structured audit tool: Linking clinical practice, quality initiatives and continuing professional development

D. Wooster. University of Toronto, Toronto, Ont.

SIGN-UP SESSION \#130

integrating assessment into the postgraduate workplace: An interactive workshop D.J. Davis. Ottawa, Ont.

\section{SIGN-UP SESSION \#131}

Destination: CanMEDS communicator - using Martin's Map to guide the teaching and learning of communication competencies

D. Martin, S. Glover Takahashi. University of Toronto,

Postgraduate Department of Medical Education,

Toronto, Ont.

SIGN-UP SESSION \#132

Beyond headlines: De-coding the public-private debate for Canadian specialists

R. McMurtry, T. Noseworthy. University of Western Ontario, London, Ont., University of Calgary, Calgary, Alta.

\section{SIGN-UP SESSION \#133}

Extended uses of formal self-assessment modules in continuing professional development (CPD)

D. Wooster, B. Capusten, R. Sidhu. University of

Toronto, Toronto, Ont., University of Calgary, Calgary, Alta., University of British Columbia, Vancouver, BC.

SIGN-UP SESSION \#134

Selecting the best residents for your program G. Bandiera, G. Regehr. University of Toronto, Wilson Centre for Research in Education, Toronto, Ont.

SIGN-UP SESSION \#137

Debate: The future of generalism in medicine J. Frank, J. Nagle, R. Ramsaran, D. Danoff, P. Rainsberry. The Royal College of Physicians and Surgeons of Canada, Ottawa, Ont., The College of Family Physicians of Canada, Mississauga, Ont.

SIGN-UP SESSION \#138

The future of postgraduate medical education: Optimizing career choice in medicine

J. Frank, J. Nagle, R. Ramsaran, D. Danoff, $P$. Rainsberry The Royal College of Physicians and Surgeons of Canada, Ottawa, Ont., The College of Family Physicians of Canada, Mississauga, Ont.

SIGN-UP SESSION \#139

The future of postgraduate medical education: Flexibility and switching careers in medicine J. Frank, J. Nagle, R. Ramsaran, P. Rainsberry. The Royal College of Physicians and Surgeons of Canada, Ottawa, Ont., The College of Family Physicians of Canada, Mississauga, Ont.

SIGN-UP SESSION \#140

The future of postgraduate medical education: The structure of residency education in the 21st century J. Frank, J. Nagle, R. Ramsaran, D. Danoff, P. Rainsberry. The Royal College of Physicians and Surgeons of Canada, Ottawa, Ont., The College of Family Physicians of Canada, Mississauga, Ont.

SIGN-UP SESSION \#141

Beyond the medical expert role: New opportunities for self-assessment programs

G. Wallace, S. Swiggum, T. Gondocz. The Canadian Medical Protective Association, Ottawa, Ont. 
Royal COLLEGE ABSTRACTS. 27

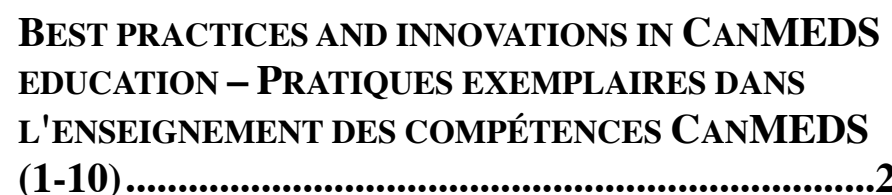

1. Communication skills training on orthopaedics K. Lundine, J. Lockyer, C. Hutchison, R. Buckley. University of Calgary, Calgary, Alta.

2. Use of a health advocacy essay to improve competence

M. Borgaonkar, D. Pace, P. Jeon. Memorial University of Newfoundland, St. John's, NL.

3. interactive online software documenting and corroborating exposure to CanMEDS roles Y. Lamarche, L.P. Perrault, G. Beauchamp, J.-F.

Renaud, S. Lamarche, M. Carrier. Institut de cardiologie de Montréal, Université de Montréal, Montréal, Qué.

4. Leadership in postgraduate medicine: Results from the first annual chief resident leadership workshop.

S. Verma, R. Zulla, J. Mikhael, A. Natsheh, S.G.

Takahashi, L. Muharuma and J. McIlory.

Postgraduate Medical Education Office, Department of Medicine, Faculty of Medicine, University of Toronto, Professional Association of Residents and Internes of Ontario, Toronto, Ont.

5. A needs assessment for a CanMEDS-based curriculum in ambulatory: Care for internal medicine residents in Canada

$R$. Wong, S. Roff. University of Toronto, Toronto, Ont., University of Dundee, Dundee, UK.

6. CanMEDisification: The role of postgraduate medicine office in supporting the learning and teaching of CanMEDs roles

S.G. Takahashi, S. Verma, L. Muharuma, R. Zulla.

Postgraduate Medical Education, Faculty of

Medicine, University of Toronto, Toronto, Ont.

7. Présentation d'un portfolio électronique pour la formation et l'évaluation des compétences CanMEDS en obstétrique-gynécologie M.-J. Dupuis, D. Girardot. Université de Montréal, Montréal, Qué.
8. Modelling and teaching collaboration: The interprofessional education in geriatric care project C. van Ineveld, R. Grymonpre, E. Boustcha, M. Nelson, A. Booth, A. De Jaeger, F. Jensen, T. Sullivan, J. Swinamer, L. Weinberg. University of Manitoba, Winnipeg, Man.

9. Innovation in research instruction: Pilot testing of team learning to promote peer reviewed grantwriting by clinician trainees

F. Warnock, J. Sibley. University of British Columbia, Vancouver, $B C$.

10. Designing an online curriculum supporting risk management and patient safety

S. Swiggum, T. Gondocz, G. Wallace. The Canadian Medical Protective Association, Ottawa, Ont.

\section{Health POliCy - PolitiQue en Matière de la} SANTÉ (11-21)

11. Who is in charge? Introducing Criteria to Evaluate Health Human Resource (HHR) Policy Documents

D. Rosenfield, C. Abrahams, S. Verma. McMaster University, Hamilton, Ont., University of Toronto, Toronto, Ont.

12. Disclosure of medical errors: A view through a global lens

J. Kalra, H. Neufeld, A. Mulla. University of Saskatchewan, Royal University Hospital, Saskatoon, Sask.

13. The impact of government regulation of ambulatory surgical facilities on access to elective surgical procedures

E. Fric-Shamji, M. Shamji. Duke University, Durham, $N C$, University of Ottawa, Ottawa, Ont.

14. influences on choice of a generalist career in general surgery, general internal medicine and general pediatrics

C. Chung, L. Nickell, Generalism Task Force.

University of Toronto, Toronto, Ont.

15. Meeting challenges in the delivery of surgical care

L. Sigurdson. Dalhousie University, Halifax, NS.

16. Postgraduate training and its effect on practice location, career choice and practice profile: 
Tracking 10 years of output from the University of Toronto

C. Abrahams, S. Verma, R. Glazier, L. Jaakkimainen, $S$. Shultz. University of Toronto, Institute for Clinical Evaluative Sciences (ICES), Toronto, Ont.

17. Boundaries or overlap: An examination of the comminity-oriented clinical practice of community medicine specialists and family general practitioners

M.L. Russell, L. McIntyre. University of Calgary, Calgary, Alta.

18. The future of canadian residency education: The core competency project

J. Frank, J. Nagle, R. Ramsarin, D. Danoff, $P$. Rainsberry. The Royal College of Physicians and Surgeons of Canada, Ottawa, Ont., The College of Family Physicians, Mississauga, Ont.

19. Prevalence of diagnostic discordance: $A$ retrospective analysis of autopsy findings and clinical diagnoses

S. Suryavanshi, J.D.Gomez, A. Mulla, J. Kalra. College of Medicine, University of Saskatchewan, Royal University Hospital, Saskatoon, Sask.

20. Does Saskatchewan health policy encourage specialization?

M.A. Megahed Gheis. University of Saskatchewan, Saskatoon, Sask., Regina Qu'Appelle Health Region, Regina, Sask.

21. Optimal care in rheumatoid arthritis: Preliminary findings from a focus group study S. Bernatsky, D. Feldman, M. Roper, E. Rosenberg. McGill University, University of Montréal, Montréal, Qué.

\section{HISTORY OF MEDICINE - HISTOIRE DE LA MÉDICINE}

(22-44) .39

22. The warden and the doctor: Kingston penetentiary in the 1840s

R. Jacques. Queen's University, Kingston, Ont.

23. Coley's toxin \& spontaneous tumour regression D.S. Hayre. University of Calgary, Calgary, Alta.

24. The controversial conquering of pain.

D. van Heerden. University of Calgary, Calgary, Alta.

25. A Christmas conundrum: What ailed Tiny Tim? L. Bogle. University of Calgary, Calgary, Alta.
26. Nothing but the truth, so help me God: The history of magnetic resonance imaging A. Dechant. University of Calgary, Calgary, Alta.

27. Immigration and other evils: A profile of Dr. C. K. Clarke and the eugenics movement in Canada L. Lee. Queen's University, Kingston, Ont.

28. Lothotomy through the ages: Big stones, small stones and all the ways to cut them out J.E. Elliott. University of Manitoba, Winnipeg, Man.

29. The changing concept of aging and the quest for immortality

D. Wile, University of Calgary, Calgary, Alta.

30. Abortion and the fall of midwifery in 19th century North America

C. Schram. Queen's University, Kingston, Ont.

31. The birth of a new specialty: The history of emergency medicine in Canada

R. Elyas. Queen's University, Kingston, Ont.

32. Relearning in military surgery: The contributions of Princess Vera Gedroits B. Wilson. University of Calgary, Calgary, Alta.

33. how to steal a body

C. Turner. University of Calgary, Calgary, Alta.

34. A bried history of cardiac arrythmia

R. Ducas. University of Manitoba, Winnipeg, Man.

35. Models that change: The study of gay identity development

K. Heng. University of Calgary, Calgary, Alta.

36. Practicing medicine and music II:

Ophthalmology and music

L.P. Hwi, J.W. Ting. Faculty of Medicine, University of Manitoba, Winnipeg, Man.

37. Unlikely bedmates: A critical look at the history of public health and prostitution

S. Berkhout. Faculty of Medicine, the Department of Philosophy, University of British Columbia, BC

Centre For Excellence in HIVIAIDS, Vancouver, BC.

38. Max Brodel (1870-1941): His artistic influence on surgical learning at John Hopkins Medical School

P. Pace-Asciak, T. Gelfand. The University of Ottawa, Ottawa, Ont. 
39. Thomas hodgkin. 1978-1866. Health advocate for Manitoba

P. Warren. University of Manitoba, Winnipeg, Man.

40. The evolution of prosthetics

A. Kam. Faculty of Medicine, University of Manitoba, Winnipeg, Man.

41. The cost of mistakes: Penalties for surgical malpractice through the ages

B.A. Vartian. University of Calgary, Calgary, Alta.

42. The psychoneuroimmunophysiological responses to incongruous actions or statements/ prevarications made for the purpose of eliciting rhythmic, spasmodic expiratory reflexes

S. Ahmed. University of Calgary, Calgary, Alta.

43. "Consider whether I show a man's wisdom":

The enigmatic Dr. James Barry

T. Afolabi. University of Toronto, Toronto, Ont.

44. Publication history of the Brugada Syndrome:

Did labeling stimulate research?

M.A. Nault, A. Baranchuk, C.S. Simpson, D.P.

Redfearn, H. Abdollah, Queen's University, Kingston, Ont.

RESEARCH IN CONTINUING PROFESSIONAL

DEVELOPMENT - LA RECHERCHE SUR LE

DÉVELOPPEMENT PROFESSIONNEL CONTINU (45-48)

45. Education at distance: Broadcasting ECG rounds to Southeastern Ontario (BESO Project). An innovative approach for teaching elctrocardiography

A. Baranchuk, G. Dagnone, P. Fowler, M.N. Harrison, L. Lisnevskaia, B. Etemadi, D. Blouin, D.P. Redfearn, C.S. Simpson. Kingston General Hospital, Queen's University, Kingston, Ont.

46. Did the CME/CPD train leave with half the passengers? A needs assessment of Quebec specialist associations' CPD units

G. Hudon, R. Laprise, L. Guindon. Fédération des médecins spécialistes du Québec, Montréal, Qué.
47. Evaluation of new implementation straegies, program effectiveness and dissemination of new padagogical knowledge: Centre for faculty development's stepping stones teaching certificate program

D. Richardson, I. Silver, A. Dionne. University of Toronto, Toronto, Ont.

48. MD/MBA: A useful combination in Canadian specialty medicine?

J. Shantz. University of Manitoba, Winnipeg, Man.

75. Learning on the run - Practical strategies for physician learning

R. Bankey, C. Campbell. Center for Learning in

Practice, the Royal College of Physicians and

Surgeons of Canada, Ottawa, Ontario, Canada.

RESEARCH IN RESIDENCY EDUCATION - LA RECHERCHE SUR LES ÉTUDES MÉDICALES POSTDOCTORALES (RÉSIDENCE) (49-74).

49. Effect of a resident-as-teacher training programme on surgical resident clinical teaching skills

Y. Ying, P. Fitzgerald, S Reid. McMaster University, Hamilton, Ont.

50. Health advocacy in surgical training: $A$ Canadian survey on attitudes and experience in urology residency

D.R. Siemens, M. Leveridge, D. Beiko, J.W.L. Wilson, Queen's University, Kingston, Ont.

51. Structured assessment format for evaluating operative reports (SAFE-OR) in general surgery A. Vergis, L. Gillman, M. Taylor, S. Minor, J. Park.

University of Manitoba, Winnipeg, Man., Dalhousie University, Halifax, NS.

52. Simulation based training improves resident competence in the performance of critical resuscitation procedures

T. Langhan, I. Rigby, I. Walker, T. Donnon, D. Howes, J. Lord. University of Calgary, Calgary, Alta.

53. Resident training and the dictated operative report - A national perspective

L.M. Gillman, A. Vergis, J. Park, M. Taylor. Department of Surgery, University of Manitoba, Winnipeg, Man. 
54. Assessing cardiac physical examination cometence using simulation technology and real patients

G. Cole, R. Hatala, S.B. Issenberg, B. Kassen, C.M. Bacchus, R.J. Scales. University of British Columbia, Vancouver, BC, University of Miami, Miller School of Medicine Centre for Research in Medical Education, Miami, FL, Royal College of Physicians and Surgeons of Canada, Ottawa, Ont., University of Calgary, Calgary, Alta.

55. Simulation based training of technical surgical skills: A review of a five-year collaborative research program supported by the RCPSC medical education fund

A. Dubrowski, V. LeBlanc, W. Gofton, G. Xeroulis, H. Carnahan. University of Toronto, Toronto, Ont., University of Ottawa, Ottawa, Ont., University of Western Ontario, London, Ont.

56. Proficiency at the end of practice predicts retention of a technical clinical skill

H. Carnahan, E. Hagemann, A. Dubrowski. University of Toronto, Toronto, Ont.

57. The power of power: comparative evaluations of medical residency training across teaching sites and programs at the University of Toronto

C. Abrahams, S. Verma, L. Muharuma, K. Imrie, $R$.

Vestemean, K. Imrie, P. Poldre, J. McIlroy, N. Woods. University of Toronto, Toronto, Ont.

58. Stories - Structured operative reporting in enteric surgery

L.M. Gillman, A. Vergis, J. Park, S. Minor, M. Taylor.

Department of Surgery, University of Manitoba,

Winnipeg, Man.

59. General medicine residents' perception of the mini-CEX

S. Malhotra, R. Hatala, C.-A. Courneya. Department of Medicine, St. Paul's Hospital, University of British Columbia Faculty of Medicine, Vancouver, BC.

60. Using a pocket card to improve end-of-life care on clinical teaching units: A controlled trial

J. Downar, J. Mikhael. University of Toronto, Toronto, Ont.

61. Primary ophthalmic care patterns and training of University of Ottawa residents

E.A. Sogbesan, A. Fournier, K. Damji. University of

Ottawa Eye Institute, Ottawa, Ont.
62. does an expert presentation raise awareness of CanMEDs roles among residents?

S. Jenkins, K. Crocker, P. Jeon, M. Borgaonkar, D.

Pace, S. Verma. Memorial University of

Newfoundland, St. John's, NL.

63. Developing a program for resident wellness at the postgraduate medical education office,

University of Toronto

S. Edwards, S. Verma, R. Zulla. Postgraduate Medical Education Office, Faculty of Medicine, University of Toronto, Toronto, Ont.

64. International child health (ICH) education in Canadian paediatric residency programs

T. Audcent, H. MacDonnell, J. Brenner, L. Samson.

University of Ottawa, Ottawa, Ont.

65. Concurrent pursuit of degrees and courses during community medicine residency: Challenges, policies and procedures

M.L. Russell, A. Robinson Vollman, T. Strudsholm.

University of Calgary, Calgary, Alta.

66. Innovation in the academic half-day CanMEDS medical expert competency for residency education K. Stobart, H.R. Rajani, C. Good. University of Alberta, Edmonton, Alta.

67. Loving your child to death: Consideration of the care of chronically ill children and euthanasia in Emil Sher's Mourning Dove and implications for medical education

K. Mukhida. University of Toronto, Toronto, Ont.

68. The resident experience in a large urban teaching setting: Results of the 2005-2006 resident exit survey, University of Toronto

N. Tenn-Lyn, S. Verma, R. Zulla. University of Toronto, Toronto, Ont.

69. International medical graduates (IMGs) needs assessment study: A comparison between curren IMG trainees and program directors

S. Verma, R. Zulla, M. Otto Baerlocher. Postgraduate Medical Education Office, Faculty of Medicine, University of Toronto, Toronto, Ont.

70. Supporting IMG integration into residency training

S. Glover Takahashi, M. Alameddine, D. Martin, S. Verma, S. Edwards. University of Toronto, Toronto, Ont. 
71. Are video interviews a good alter-narative to in person interviews in assessing international applicants'skills?

M. Alameddine, K. Imrie, S. Akers, S. Verma.

University of Toronto, Toronto, Ont.

72. Evalutation of an innovative mentorship program - Multilevel mentorship model - Does it meet the needs of residents?

C.T.J. Elliott, J. Buxton, S. Froese. Department of Health Care and Epidemiology, University of British Columbia, Vancouver, BC.

73. "I just don't want to kill anybody": The first six months of postgraduate training

D. Martin, S. Glover Takahashi. Department of Family and Community Medicine, University of Toronto, Toronto, Ont.

74. Remediation plans: Effectively matching trainee needs to remediation plans

S. Glover Takahashi, D. Martin, S. Verma, S. Edwards.

University of Toronto, Toronto, Ont.

YOUNG INVESTIGATORS FORUM. 70

The role of THOA in calcium sensitization in human myometrial smooth muscle

Hector Aguilar and B.F. (Peter) Mitchell, University of Alberta.

Effects of maternal nutrient restriction on placental morphology and insulin-like growth factor system expression

C Albion, S Dixon, K Nygard, C Reid and V Han, Department of Obstetrics and Gynaecology, Paediatrics and Anatomy and Cell Biology, Children's Health Research Institute and Lawson Health Research Institute, The University of Western Ontario, London, Ontario, Canada

Atomoxetine, but not paroxetine, blocks norepinephrine reuptake in depressed patients F. Aldosary, P. Tremblay, C. Hébert, and P. Blier. University of Ottawa Institute of Mental Health Research, Ottawa, ON

Global gene expression analyses in early experimental osteoarthritis reveal novel players in articular cartilage degeneration Tom Appleton, CIHR Group in Skeletal Development \& Remodeling, Dept. of Physiology \& Pharmacolgy, University of Western Ontario,
Shirine Usmani, Vasek Pitelka, Dept. of Physiology \& Pharmacolgy, University of Western Ontario, Jim Henry, Dept. of Physiology \& Pharmacolgy, University of Western Ontario, Michael G. Degroote Institute for Pain Research \& Care, McMaster University,

Suzanne Bernier, CIHR Group in Skeletal Development \& Remodeling, Dept. of Anatomy \& Cell Biology, University of Western Ontario,

Frank Beier, CIHR Group in Skeletal Development \& Remodeling, Dept. of Physiology \& Pharmacolgy, University of Western Ontario

Profiling YB-1 responsive genes in basal-like breast cancer cells by ChIP-on-chip reveals direct binding to PIK3CA

Astanehe A, MD/PhD Program, University of British Columbia, Vancouver, BC, Laboratory for Oncogenomic Research, Departments of Pediatrics, Experimental Medicine and Medical Genetics, University of British Columbia, Vancouver, BC

Finkbeiner M, Jiang H and SE Dunn, Laboratory for Oncogenomic Research, Departments of Pediatrics, Experimental Medicine and Medical Genetics, University of British Columbia, Vancouver, BC

The character of anti-HCV T cell responses differs between spontaneous and treatment-induced viral clearance

Barrett, L, Immunology Program, Memorial University of Newfoundland, St. John's, NL, Department of

Medicine, Dalhousie University, Halifax NS

$G$ Hirsch, Department of Medicine, Dalhousie University, Halifax NS

M Gallant, C Howley, Immunology Program, Memorial University of Newfoundland, St. John's, $N L$,

K Peltekian, Department of Medicine, Dalhousie University, Halifax NS,

M Grant, Immunology Program, Memorial University of Newfoundland, St. John's, NL

Through the looking-glass: Objectivity, interpretation, and the construction of social kinds as emerging issues in research ethics

Berkhout SG, MD/PhD Program, University of British Columbia, Vancouver, BC, The Centre for Excellence in HIVIAIDS, Vancouver, BC, Department of Philosophy, University of British Columbia, Vancouver, BC, 
Tyndall MW, The Centre for Excellence in HIVIAIDS, Vancouver, BC,

$S$ Anderson, Department of Philosophy, University of British Columbia, Vancouver, BC

Rapid electrical pacing of cardiomyocytes alters the behavior of cardiac fibroblasts: Implications for atrial fibrillation

Brett Burstein, MD/PhD Program, McGill University, Montreal, QC, Department of Pharmacology, McGill University, Montreal, QC, Research Centre, Montreal Heart Institute, Montreal, $Q C$,

Xiao-Yan Qi, Research Centre, Montreal Heart Institute, Montreal, $Q C$,

Angelino Calderone, Research Centre, Montreal Heart Institute, Montreal, QC, Department of Physiology, University of Montreal, Montreal, QC,

Stanley Nattel, Department of Pharmacology, McGill University, Montreal, QC, Research Centre, Montreal Heart Institute, Montreal, $Q C$

The role of AMP-activate protein kinase (AMPK) in the regulation of cardiac hypertrophy

Anita Y. M. Chan, Cardiovascular Research Group,

Carrie-Lynn M. Soltys, Cardiovascular Research Group, Department of Pediatrics, , University of Alberta, Edmonton, Alberta

Jason R. B. Dyck. Cardiovascular Research Group, Departments of Pediatrics and Pharmacology, University of Alberta, Edmonton, Alberta.

The metalloproteinase ADAM10 is required for retinal ganglion cell axon guidance in the developing visual system

Y.Y. Chen, C.L. Hehr, K. Atkinson-Leadbeater, J.C.

Hocking, S. McFarlane. University of Calgary,

Calgary, $A B$

In vitro validation of a 3-dimensional transrectal ultrasound system for prostate biopsies

Derek Cool, Dept. of Medical Biophysics, Robarts

Research Institute, London, Ontario,

Shi Sherebrin, Robarts Research Institute, London,

Ontario,

Jonathan Izawa, Joseph Chin, Dept. of Surgery,

Division of Urology, University of Western Ontario,

Aaron Fenster, Dept. of Medical Biophysics, Robarts

Research Institute, London, Ontario
Molecular characterization of the development of the K65R and M184V drug resistance mutations in Subtype C HIV-1

Dimitrios Coutsinos, MD-PhD Program, McGill University, Montreal QC, McGill University AIDS Center, Montreal $Q C$, and the Departments of Microbiology \& Immunology, and Medicine, McGill University, Montreal QC,

Cédric F. Invernizzi, McGill University AIDS Center, Montreal QC, Department of Medicine, McGill University, Montreal QC,

Daniela Moisi, Maureen Oliveira, McGill University AIDS Center, Montreal QC,

Bluma G. Brenner, Mark A. Wainberg2,3,4, McGill University AIDS Center, Montreal QC, Departments of Microbiology \& Immunology, and Medicine, McGill University, Montreal QC

Elucidating the role of P63 during development of the mammalian nervous system

Sagar Dugani, Annie Paquin, David R. Kaplan, and Freda D. Miller. Institute of Medical Science, University of Toronto, Developmental Biology, The Hospital for Sick Children.

A JNK-dependent switch determines the oncogenic or tumor suppressor activity of ILK

Durbin $A D^{*}$, The Department of Medical Biophysics, MD/PhD Department, University of Toronto, Toronto, ON. Division of Hematology/Oncology-Departments of Pediatrics, The Hospital for Sick Children,

Toronto, ON,

Somers GR, Department of Laboratory Medicine and Pathobiology, University of Toronto, Toronto, ON, Pediatric Laboratory Medicine5, The Hospital for Sick Children, Toronto, ON,

Forrester M, Division of Hematology/OncologyDepartments of Pediatrics, The Hospital for Sick Children, Toronto, ON

Hannigan GE, Department of Laboratory Medicine and Pathobiology, University of Toronto, Toronto, ON,

Malkin D. The Department of Medical Biophysics, University of Toronto, Toronto, ON. Division of Hematology/Oncology-Departments of Pediatrics, The Hospital for Sick Children, Toronto, ON 
Abnormal neurogensis in the hippocampus of a mouse model of fragile $X$ syndrome

Eadie B, MD/PhD Program, University of British Columbia, Vancouver, BC, Neuroscience Graduate Program, University of British Columbia, Vancouver, $B C$,

B Christie, Neuroscience Graduate Program, University of British Columbia, Vancouver, BC

Innate inflammatory and phagocytic responses to Plasmodium falciparum: linked processes or molecularly discrete pathways?

Laura Erdman, Gabriela Cosio, Samir N. Patel, Sergio Grinstein, Kevin C. Kain, McLaughlin-Rotman Centre for Global Health, University of Toronto, Toronto, Canada

Targeted deletion of discoidin domain receptor 1 (Ddr1) decreases atherosclerosis, reduces inflammation and accelerates matrix accumulation in $L D L$ receptor deficient mice

Christopher Franco, Guangpei Hou, Wolfgang Vogel, Michelle Bendeck. Department of Laboratory Medicine \& Pathobiology, Faculty of Medicine, University of Toronto, Toronto.

A screen for suppressors of apoptosis identifies a novel gain of function mutation in drosphilia RAS1 Gafuik C., Agapite J. and Steller H. Howard Hughes Medical Institute, Strang Laboratory of Apoptosis and Cancer Research, The Rockefeller University, 1230 York Avenue, New York, NY 10021, USA

Golgi-bound Rab34 is a novel member of the secretory pathway

Neil M. Goldenberg, Institute of Medical Science and

Department of Medicine, University of Toronto,

Toronto, Ontario, Canada,

Sergio Grinstein, Department of Medicine, University

of Toronto, Toronto, Ontario, Canada,

Mel Silverman, Program in Cell Biology, Hospital for

Sick Children, Toronto, Ontario, Canada

Relative value of plasma nitrotyrosine for predicting mortality in patients with coronary artery disease

Heslop CL, MD/PhD Program, University of British Columbia, Department of Pathology and Laboratory Medicine, St. Paul's Hospital, Vancouver, BC
Frohlich JJ, JS Hill, Department of Pathology and Laboratory Medicine, St. Paul's Hospital, Vancouver, $B C$

High affinity IL-2 receptor (CD25) expression among Chronic Lymphocytic leukemia (CLL) patients is independent of mutational status and ZAP-70 positivity

Howell, JM; Luider, J; Wong, H; Perrizolo, M; Demetrick, D; Auer, I; Mansoor, A. Department of Pathology and Laboratory Medicine, University of Calgary / Calgary Laboratory Services (CLS), Calgary Alberta Canada.

Differential expression of type I interferon genes in plasmacytoid dendritic cells from HIV-infected patients

Martin D. Hyrcza, Sandy S. Der, Mario Ostrowski, University of Toronto, Department of Laboratory Medicine and Pathobiology, MD/PhD Program

Spatial localization of unknown proteins in the endoplasmic reticulum predicts function Michael D. Jain, Department of Anatomy and Cell Biology, McGill University, Montreal, QC, MD-PhD program, McGill University

Hisao Nagaya, Annalyn Gilchrist, Department of Anatomy and Cell Biology, McGill University, Montreal, $Q C$

Miroslaw Cygler, Biotechnology Research Institute, National Research Council of Canada, Montreal, QC John J.M. Bergeron, Department of Anatomy and Cell Biology, McGill University, Montreal, $Q C$

Modulation of NMDA receptors by prion protein Houman Khosravani, Yunfeng Zhang, Shigeki Tsutsui, Shahid Hameed, Jawed Hamid, Christophe Altier, Frank R. Jirik, Gerald W. Zamponi. Hotchkiss Brain Institute, University of Calgary, Canada

Genetic characterization of two autosomal recessive disorders, Majewski-like and cerebral atrophy syndrome

Lahiry P, Robinson JF, Vascular Biology Research

Group, Robarts Research Institute, London, Ontario,

Siu V, Department of Pediatrics, University of Western

Ontario, London, Ontario,

Puffenberger EG, Strauss KA, Clinic for Special

Children, Strasburg, Pennsylvania,

Hegele RA, Vascular Biology Research Group, Robarts Research Institute, London, Ontario, 
Rupar CA, Child Health Research Institute, University of Western Ontario, London, Ontario

A genome-wide linkage scan for familial partial lipodystrophy susceptibility genes in a German kindred

M. Lanktree, J. Robinson, J. Creider, H. Cao, D. Carter, D. Horsch, R. Hegele. Robarts Research Institute, Schulich School of Medicine and Dentistry, University of Western Ontario, London, Ont., Philipps-University, Marburg, Germany

Modulating hedgehog and beta-catenin signaling in osteoarthritis

A. C. Lin, B. A. Alman University of Toronto, Toronto, ON

Determinating the role of the E3 Ubiquitin Ligase Ariadne 2 in mammalian systems

A.E. Lin*, A.Wakeham, A. You-Ten, G. Wood, T. W. Mak. Department of Medical Biophysics, Princess Margaret Hospital, University of Toronto, Canada.

Attention and grasping in Parkinsons disease: Effects of treatment and disease stage

Cathy Lu, Oksana Suchowersky, Zelma Kiss, and Angela M Haffenden, Department of Clinical Neurosciences and Hotchkiss Brain Institute, University of Calgary, Calgary, Alberta

Characterization of low grade serous carcinoma of the ovary and its precursors

Taymaa May, Department of Obstetrics \& Gynecology, Samuel Lunenfeld Research Institute, Institute of Medical Sciences, University of Toronto,

Monika Sharma, Microarray Centre, Ontario Cancer Institute,

Igor Jurisica, Division of Signaling Biology, Ontario Cancer Institute,

Barry Rosen, Joan Murphy, Division of Gynecological

Oncology, Princess Margaret Hospital,

Patricia Shaw, Department of Laboratory Medicine and Pathology, University Health Network,

Theodore Brown, Department of Obstetrics \& Gynecology, Samuel Lunenfeld Research Institute,

Institute of Medical Sciences, University of Toronto

Memory from one-trial training is resistant to extinction in Lymnaea Stagnalis

Kara Murias, Martin Amarell, Ken Lukowiak. Hotchkiss Brain Institute, University of Calgary, Canada
Response of human osteoblast-like cells to fluid flow shear: A potential role for the microtubule network and primary cilium

Kenneth A. Myers, Dr. Jerome B. Rattner, Dr. Nigel G. Shrive, Dr. David A. Hart, McCaig Centre for Joint Injury \& Arthritis Research, Alberta Bone \& Joint Health Institute, University of Calgary

Examination of the dynamics of global DNA methylation pattern establishment during spermatogenesis

Kirsten Niles, MD/PhD Program, McGill University, Montreal Children's Hospital Research Institute and Departments of Pediatrics, Human Genetics and Pharmacology \& Therapeutics, McGill University, Montreal, $Q C$,

Sophie La Salle, Christopher Oakes, Jacquetta Trasler, Montreal Children's Hospital Research Institute and Departments of Pediatrics, Human Genetics and Pharmacology \& Therapeutics, McGill University, Montreal, $Q C$

The role of CRMP4 in nerve regeneration Stephan Ong Tone, Yazan Z. Alabed, Alyson E. Fournier, MD/PhD Program, McGill University, Department of Neurology and Neurosurgery, Montreal Neurological Institute

Heparin induces amyloid formation in cultured human islets

Potter K, MD/PhD Program, and Child and Family Research Institute, University of British Columbia, Vancouver, $B C$,

Park K, CB Verchere, Child and Family Research Institute, University of British Columbia, Vancouver, $B C$

\section{Stepping up regulatory mechanisms of GLUT4} traffic in L6 skeletal muscle cells

V.K. Randhawa, Programme in Cell Biology, Hospital for Sick Children, Toronto, Canada; Department of Biochemistry, University of Toronto, Canada,

I. Talior-Volodarsky, Programme in Cell Biology, Hospital for Sick Children, Toronto, Canada,

A. Klip, Programme in Cell Biology, Hospital for Sick Children, Toronto, Canada; Department of Biochemistry, University of Toronto, Canada 
Intestinal microbiota balance modulates host susceptibility to infection with enteric pathogens Sekirov I, MD/PhD Program, and Michael Smith Laboratories, University of British Columbia, Vancouver, BC

Tam N, Robertson M, Lupp C, B Finlay, Michael Smith Laboratories, University of British Columbia, Vancouver, BC

Development of a thermally responsive peptide for sustained deliver of solyble TNF receptor II to attenuate inflammatory events associated with radiculopathy

Mohammed F. Shamji, Dept of Biomedical Engineering, Duke Univ, Div of Neurosurgery, Dept of Surgery, The Ottawa Hospital,

Odelia Ghodsizadeh, Dept of Biomedical Engineering, Duke Univ,

Allan H. Friedman, Div of Neurosurgery, Dept of Surgery, Duke Univ Medical Center, Durham, NC William J. Richardson, Div of Orthopaedic Surgery, Dept of Surgery, Duke Univ Medical Center, Durham, $N C$

Ashutosh Chilkoti, Dept of Biomedical Engineering, Duke Univ,

Lori A. Setton, Depts of Biomedical Engineering and Surgery, Duke Univ

The Dynactome-investigating dynamic network motifs of kinases

Jonathan So, Kelly Elder, Karen Colwill, Rune Linding, Tony Pawson. Samuel Lunenfeld Research Institute, Toronto

Prevalence of metabolic syndrome in never treated mood disordered patients

Valerie Taylor, Dept. Medical Science, McMaster

University, Dept. Psychiatry and Behavioral

Neuroscience, McMaster University,

Glenda M. MacQueen, Dept. Psychiatry and

Behavioral Neuroscience, McMaster University

Mast cells release cytokines in response to mediators produced by virus-infected epithelial cells

Candy Tsang, and A.D. Befus. Pulmonary Research Group, Department of Medicine, University of Alberta, Canada
Gene transfer of endothelial NO-synthase restores migratory capacity of endothelial progenitor cells from patients with coronary artery disease Michael R. Ward, Qiuwang Zhang, Duncan J. Stewart and Michael J.B. Kutryk. Terrence Donnelly Vascular Biology Laboratories, St. Michael's Hospital, University of Toronto, Toronto, Ontario

The warburg effect and tumour cell survival in human GBM

Wolf A, Mukherjee, Arthur \& Sonia Labatts Brain

Tumour Center, Hospital for Sick Children,

Guha A, Arthur \& Sonia Labatts Brain Tumour Center, Hospital for Sick Children; Div. of Neurosurgery, Western Hospital, Univ. of Toronto

An analysis of the adaptive immune response towards an embryonic stem cell graft

Douglas Wu, University of Alberta and the 2Nuffield

Department of Surgery, University of Oxford, UK,

Kathryn Wood, Nuffield Department of Surgery,

University of Oxford, UK

Distribution and expression of transgene green fluorescent protein in mice survived up to four weeks following in utero gene therapy

PT Yang, L Huang, WW Jia, ED Skarsgard, C Sy, Division of Pediatric Surgery and Neurosurgery, Department of Surgery, University of British Columbia, Vancouver, Canada

Regulation of huntingtin palmitoylation and its role in Huntington Disease Young FBJ, MD/PhD Program, and Centre for Molecular Medicine and Therapeutics, andChild and Family Research Institute, University of British Columbia, Vancouver, $B C$,

MR Hayden, Centre for Molecular Medicine and Therapeutics, and Child and Family Research Institute, University of British Columbia, Vancouver, $B C$

AUTHOR INDEX.........................................100 


\section{CONCURRENT SESSIONS}

\section{CONCURRENT SESSIONS ABSTRACTS - RÉSUMÉS DES SESSIONS CONCOMITANTES}

SIGN-UP SESSION \#113

Health systems change through learning collaboratives: Multidisciplinary partnerships in paediatric health care

\author{
J. Houbé, M. Inkelas, M. O'Donnell.,University of \\ British Columbia, Vancouver, BC, University of \\ California-Los Angeles School of Public Health, \\ Los Angeles, CA.
}

Paediatricians typically work in parallel with general medical practitioners and early intervention, care, and education service providers to support families' efforts to promote the best developmental outcomes for their young children. There are few intrinsic provisions in health service systems that support the collaborator role of physicians through interprofessional consultation and coordination around developmental health care for young children at risk or diagnosed with developmental disorders. Providing timely, effective, and tailored care in support of positive outcomes for these children is a complex task currently made more difficult by fragmented service systems and tools. The Early Developmental Screening and Intervention Initiative (EDSI) Learning Collaborative in Los Angeles County has been created to tackle these problems and to create new systems of support for families with young children through interdisciplinary collaboration between physicians, nurses, early childhood educators, administrators, and parents. Their mission is to transform the way developmental surveillance, screening and support services are provided to families with young children. This symposium will discuss the principles and practical issues around the multidisciplinary learning collaborative model of health service system change, the experience of the EDSI Learning Collaborative in creating new models of paediatric health care delivery, and potential applications in Canada.
Inkelas M. The health of young children in California: findings from the 2001 California Health Interview Survey. Los Angeles, Calif.: UCLA Center for Health Policy Research; Sacramento, Calif.: First 5 California, [2003].

Inkelas M, et al. Continuity of Primary Care Clinician in Early Childhood. Pediatrics 2004. 113, 6: 1917-1925.

Jenkins ML, Houbé J. Review of Best Practices in Canada and Internationally for Healthy Child Development: Key Legislation. 2004.

\section{SIGN-UP SESSION \#114}

\section{Challenges of surgical specialties: Beyond corpora-} tism.

\section{S. Dubé, G. Beauchamp, P. Bourgouin, J. Dubois, R. Ghali, B. Montreuil, L. Valiquette. University of Montréal, Montréal, Qué.}

How do we train the next generation of vascular and neurosurgical specialists when the optimal physical installations and technical breakthroughs are in the hands of the radiologists and cardiologists? Our institution is trying to come to grips with this upcoming challenge. Dialogue starts, but faces big challenges. Dwindling financial resources and increased costs for new technologies mandates a rational use of existing expertise and co-operation to diminish the otherwise onerous financial costs. Although technical expertise in these newly developing fields is for the moment generally limited to non-surgeons, the patients are still being consulted, evaluated and treated by surgeons. Complications, even if rare, most often need to be treated by surgeons whose technical expertise demands constant practice of their skills to remain competent. The blurring of clinical and technical lines within specialties imposes a frank dialogue among all the stakeholders. As educators, we need to display leadership and work together to get beyond petty corporatism. Patients deserve the best treatments available with the best possible outcomes at the best possible cost. Currently, quarrels are partly solved by allowing duplication of technological setups, thus pleasing all involved, but obviously creating increased expenditures. Clearly the time has come to stop paying lip service to collaboration within the profession and create true avenues of discussion and co-operation. 
We can initiate a dialogue to cope with this new paradigm, putting forward the need to provide the best possible training of a hybrid specialist rather than promoting a win-loss solution among three or four specialties. Change creates anxiety but we need to document better ways of providing the best possible training in order not to waste human and financial resources. Sharing our intervention with others might help to improve the reflection and the process. Leaderships must come from the faculty involved in educating these future specialists.

\section{SIGN-UP SESSION \#115}

\section{The art of setting learning objectives}

\section{G. Bandiera, N. Tenn-Lyn. University of Toronto, University Health Network, Toronto, Ont.}

Clinical teachers have a mandate to provide relevant medical teaching that is tied to defined competencies. Today's teaching environment necessitates efficient use of time and resources. Working with students to set appropriate and meaningful learning objectives can address both of these requirements, yet teachers often find learning objectives difficult to understand and hard to develop with learners. Helping learners develop good objectives is an opportunity to both facilitate efficient teaching and role model the process of lifelong learning. This workshop will expose participants to relevant literature underpinning learnercentredness and objective-setting, help them understand the common factors influencing learners' choice of objectives, and equip them to help set learning objectives while avoiding common pitfalls. Participants will leave with a better understanding of the role of the teacher in objective setting and strategies to help them fulfill this role effectively and with confidence.
SIGN-UP SESSION \#116

\section{Collaboration between family physicans and other specialists: How can we teach this?}

\section{Nasmith. S. Dojeiji. University of British Columbia, Vancouver, BC, University of Ottawa, Ottawa, Ont.}

Through a joint project entitled Family Physicians and Other Specialists: Working and Learning Together, The Royal College of Physicians and Surgeons of Canada and the College of Family Physicians of Canada have identified a number of recommendations to improve the collaboration between these two groups of physicians. Postgraduate programs across all disciplines are challenged to incorporate curricula that will teach residents the knowledge, skills, and attitudes needed to communicate and work with each other to ensure effective and quality care for our patients.

By the end of this workshop, participants will be able to define the key elements to successful collaboration between family physicians and other specialists; identify objectives for their programs; identify teaching methods to achieve these objectives; determine the steps needed to accomplish this in their own programs.

Beaulieu MD, Samson L, Rocher G, Rioux M, Boucher L. Collaboration between family physicians and medical specialists: the gulf between preferred and actual practice. Project funded by the RCPSC.

Marshall MN. Qualitative study of educational interaction between general practitioners and specialists. BMJ 1998;316:442-45.

Keely E, Dojeiji S, Myers K. Writing effective consultation letters: 12 tips for teachers. Medical Teacher 2002;24(6):585-89

\section{SIGN-UP SESSION \#117}

\section{Learning on the Run: Practical tools to enhance self-directed learning in practice}

C. Campbell, R. Bankey. The Royal College of Physicians and Surgeons of Canada, Ottawa, Ont.

Learning on the run means that learning takes place wherever you are, in your office, over lunch, and oc- 
curs on a daily basis, perhaps in small amounts of time over the course of one's work routine. In this way a physician's daily work schedule becomes the central opportunity for learning, updating skills, gaining information, and enhancing relationships. In other words, learning and the learning context is driven by one's practice context as well as by one's own career goals and needs, and what one learns is shaped by immediate practical needs alongside current or ongoing projects. This workshop will provide participants with a greater understanding of the philosophy that underpins learning on the run and more importantly the development of skills and strategies to enhance learning on the run. The workshop will conclude with an opportunity for participants to refine a learning on the run tool, developed and piloted by the Center for Learning in Practice, for their use in practice.

\section{SIGN-UP SESSION \#118}

\section{Panel discussion: The many faces of health human resources planning.}

\section{P. Shrichand, D. Fréchette. The Royal College of Physicians and Surgeons of Canada, Ottawa, Ont.}

This session will provide an insight into health human resources (HHR) planning studies and initiatives in Canada and place this work within the context of emerging thinking in the area of overall health system reform. Physicians and nurses comprise the two largest groups of health professionals and both have undertaken comprehensive studies, via Task Force Two and the Nursing Sector Study. Simultaneously, governments, through the Advisory Committee on Health Delivery and Human Resources (ACHDHR), have developed a comprehensive framework for all health professions entitled "A Framework for Collaborative Pan-Canadian Health Human Resources Planning”. HHR planning is thus being undertaken by both health professions and by governments, but not necessarily in tandem. Emerging thinking, such as the concept of a "health commons" proposed by Ed O'Neil proposes a framework to bring together all stakeholders involved in the health system to address issues including HHR.
Task Force Two, "A Physician Human Resource Strategy for Canada: Final Report." Mar 2006. 20 Apr 2007 http://physicianhr.ca/reports/TF2FinalStrategicReport-e. pdf.

Villeneuve M, MacDonald J. (2006). Toward 2020: Visions for Nursing.

Ottawa, ON: Canadian Nurses Association.

Advisory Committee on Health Delivery and Human Resources (ACHDHR), "A Framework for Collaborative Pan-Canadian Health Human Resources Planning." Sep 2005. 8 Apr 2007

http://www.hc-sc.gc.ca/ahc-asc/alt_formats/ccs-scm/pdf/ public-consult/col/hhr-rhs/PanCanHHR_Framework_sept05_e.pdf.

\section{SYMPOSIUM \#119}

\section{Clinician investigators: Pathway to future success}

B. Winston. University of Calgary, Calgary, Alta.

In today's environment where clinician investigator training is long and the research funding environment is challenging, it is critically important for trainees and junior investigators to understand how to shape a successful career path, how to understand the value of mentorship and how to understand where research funding opportunities will exist in the future. To this end, this year's CSCI symposium will focus on ways to maximize success for the clinician investigator. The target audience is young and established investigators pursuing research-oriented careers within academic medicine, clinical and medical research trainees, scientists, and clinicians who are interested in learning more about effective strategies for putting research into practice.

The session will focus on: (a) identifying strategies for incorporating basic and clinical research into a successful career path; (b) learning about the skills/ experience required for research and the importance of mentoring for clinical investigators; (c) describing practices that research leaders have used to successfully establish themselves as clinician investigators; and (d) increase the understanding of research funding available for clinical investigators now and in the future. 
SIGN-UP SESSION \#120

\section{Slowing down when you should: A new model of intra-operative judgment and its implications for teaching.}

\author{
C-A. Moulton, G. Regehr, H. MacRae. University of \\ Toronto, Department of Surgery, Toronto, Ont.
}

The development of surgical judgment is a key factor in the training and competence of a surgeon. Though it is central to any surgical training program, means of teaching and assessing the development and acquisition of judgment are ill-defined. In part, this is due to a lack of understanding of the construct of surgical judgment. When considering whether a surgeon has adequate judgment, we often defer to their decision making ability. In fact, judgment may have occurred before the decision is made and may not always be a conscious process. The surgeon who ploughs through the bile duct when performing a cholecystectomy lacks judgment. The fact that the surgeon did not slow down infers that he or she ignored essential cues to do so, which may or may not have been a conscious decision. What is it that causes a surgeon to slow down when he or she should? What cues are available preoperatively and peri-operatively that surgeons respond (or don't respond) to? We propose a new model for thinking about intra-operative judgment: one that incorporates attention, situational awareness, anticipation, cognitive expertise, and Schőn's model of reflection-in-action. Each one of these areas brings with it a distinct body of literature that may inform what it is we are talking about when we refer to surgical 'judgment'.

We need to develop a language that will allow discourse on this very important topic so that a deeper understanding of this construct is facilitated. Instances that demonstrate judgment in the operating room need to be clarified, as do ways of teaching it explicitly, rather than the current reliance on learning intraoperative judgment through osmosis.

Through discussion and small group participation, this workshop will endeavor to: review the current literature regarding judgment and expertise; encourage surgeons and educators to think about the issue of surgical judgment; explore how surgical judgment may be displayed in the operating room setting; discuss how we could use these moments as teaching opportunities.

Kahneman D. Attention and Effort. Englewood Cliffs, NJ: Prentice-Hall Inc; 1973.

Endsley MR. Toward a theory of situation awareness in dynamic systems. Human Factors 1995; 37:32-64.

Schön DA. The reflective practitioner: how professionals think in action. New York: Basic Books; 1983.

\section{SIGN-UP SESSION \#121}

\section{When a community hospital becomes an academic centre}

\section{Topps, M. Wilson, W. McCready, K. Ferris, North- ern Ontario School of Medicine, Sudbury, Ont.}

With the advent of mandatory community rotations for some RCPSC programs and the current trend towards distributed education and training, many hospitals and clinicians with little or no prior academic involvement are being approached to accept residents. Traditional academic hospital environments have a tacit understanding of the requirements of accredited educational institutions, enhanced by regular RCPSC surveys. This is, however, new territory for community settings.

By focusing on specific challenges which have already been encountered and engaging in discussions around experiences of others, documents, templates and guidelines will be developed which will ease the transition of expansion to distributed sites. Examples of areas which are particularly germane for distributed programs include: the changing preceptor model with layering of learning; innovative clinical teaching services; funding and payment arrangements including hospital costs and resource provision; specific local roles as required for accreditation and the different roles, functions and expectations of other health professionals in the institution.

Shared resources for this growth area in medical education are a valuable commodity for all programs contemplating or in the early stages of community engagement. 
Wachter RM, et al. Reorganizing an academic medical service: impact on cost, quality, patient satisfaction and education, JAMA, 1998 May 20; 279(19):1560-5

Racine AD, et al. Upstairs downstairs: vertical integration of a pediatric service. Pediatrics $1998 \mathrm{Jul}$; 102(1 Pt 1):91-7

Rogut L. Beyond the clinic: redefining hospital ambulatory care. Pap Ser United Hosp Fund NY. 1997 Jul: 1-62

\section{SIGN-UP SESSION \#122}

\section{The CanMEDS Communicator role in the 'real world': Taking Communication skills teaching to the bedside}

\section{L.J. Cooke, S. Dojeiji. University of Calgary, Calgary, Alta., University of Ottawa, Ottawa, Ont.}

The CanMEDS project has spurred residency programs to implement a variety of innovative formal communication skills training programs. A formal communication curriculum is essential to introduce knowledge and skills. However ideally, the learning that occurs through 'formal curricula' should be reinforced informally, yet explicitly, by all clinical teachers. This means incorporating communication skills teaching into everyday practice.

Feedback from faculty development workshops about formal communication skills curricula has shown that clinical teachers desire a systematic approach to teaching communication skills in informal settings as well. How can a skills-based guide to communication skills training be applied to teach communication skills during day-to-day practice in 'teachable moments'?

This highly practical, interactive workshop will engage participants in methods to teach communication skills in their daily practice. The presenters will introduce a step-by-step approach to using the Calgary Cambridge Guides at the bedside, on the wards, and in other day-to-day clinical teaching opportunities.

Through interactive small group work and casebased scenarios, participants will develop a systematic approach to applying a structured communication skills model to every-day clinical teaching and find practical ways to apply it in their varied interactions with learners and patients.
Frank JR, Jabbour M, et al. CanMEDS 2005 Framework. Report of the CanMEDS Phase IV Working Groups: Ottawa, the Royal College of Physicians and Surgeons of Canada. March, 2005.

Kurtz S, Silverman J, Draper J. Teaching and Learning Communication Skills in Medicine, $2^{\text {nd }}$ Edition. Radcliffe Publishing, Oxford and San Francisco, 2005.

Silverman J, Kurtz S, Draper J. Skills for Communicating with Patients, $2^{\text {nd }}$ Edition. Radcliffe Publishing, Oxford and San Francisco, 2005.

\section{SIGN-UP SESSION \#123}

\section{How to build a physician health curriculum for your residency program}

\section{Puddester, J. Cohen, L. Flynn. University of Ot-} tawa, Ottawa, Ont., University of Calgary, Calgary, Alta., Queen's University, Kingston, Ont.

Physician health, wellness, and sustainability is an area of growing concern and interest in medical education and training. The Royal College of Physicians and Surgeons have recently embedded physician health within the conceptual framework of the Professional role, and many postgraduate training programs in Canada have strived to incorporate this theme into their curriculum. However, there has also been a growing, albeit informal, discussion about the need to develop, implement, and evaluate models of curriculum in physician health that can be shared amongst programs. There has also been an informal discussion that while there are common principles of physician health that can readily applied to a general curriculum regardless of specialty, there has also been an acknowledgment that programs may need to develop specialty-specific curriculum in order to best meet learner need. This workshop is designed to allow those involved with postgraduate education and training immerse themselves in this area and work collaboratively with content experts and peers in order to develop their own models of curriculum for application in their specific programs.

Bergman B, Ahmad F, Stewart DE. Physician health, stress and gender at a university hospital. Journal of Psychosomatic Research. 54(2):171-8, 2003 Feb. 
Taub S, Morin K. Goldrich MS. Ray P. Benjamin R. Physician health and wellness. Occupational Medicine (Oxford). 56(2):77-82, 2006 Mar.

Oandasan IF. Health advocacy: bringing clarity to educators through the voices of physician health advocates. Academic Medicine. 80(10 Suppl):S38-41, 2005 Oct.

Puddester DG. Canada responds: an explosion in doctors' health awareness, promotion and intervention. Medical Journal of Australia. 181(7):386-7, 2004 Oct 4.

\section{SIGN-UP SESSION \#124}

\section{Medical education and health technology assess- ment: Creating partnerships to address the Can- MEDS roles of manager and health advocate}

M. Allen, D. Sinclair, D. Juzwishin, D. Husereau. Dalhousie University, Halifax, NS, Juzwishin Consulting Inc., St. Albert, Alta., Canadian Agency for Drugs and Technology in Health, Ottawa, Ont.

The term "health technology" refers to drugs, medical devices, and procedures. Systematic reviews synthesize the evidence for the efficacy of these technologies. However, the adoption of a health technology has implications that extend beyond efficacy. Health technology assessment evaluates other factors such as safety, cost, cost-effectiveness, effects on health care organizations and systems, and ethical issues of access to the technology.

Applying the principles of health technology assessment can help physicians fulfill the CanMEDS Roles of Manager and Health Advocate, Roles that educators find challenging to address. Some of the elements and competencies of the Manager and Health Advocate Roles that can be addressed by a health technology approach are:

- Allocation of finite health care resources appropriately;

- Physicians as active participants in the health care system;

- Responding to the health needs of the communities they serve;

- Appreciation of the possibilities of competing interests between the communities served and other populations.
Although health technology assessment can help address these CanMEDS Roles, few physicians and medical educators are aware of its potential and the resources available to them. There are four health technology assessment agencies in Canada and 45 around the world that can help residents, program directors, and practicing physicians fulfill these CanMEDS Roles. The purpose of this symposium is to inform educators about health technology assessment and discuss with them its role in addressing the CanMEDS Roles of Manager and Health Advocate.

Rosen R, Gabbay J. Linking health technology assessment to practice. BMJ 1999;319:1292-4

Bozic KJ, Pierce RG, Herndon JH. Health care technology assessment. Basic principles and clinical applications. J Bone Joint Surg Am 2004; 86-A(6):1305-1314.

Chantler C. Health-care technology assessment: a clinical perspective. Int $\mathrm{J}$ Technol Assess Health Care 2004; 20(1):87-9

\section{SIGN-UP SESSION \#125}

\section{Continuing education for collaborative mental health care: An interprofessional education, e- learning approach}

\section{E. Pauzé, F. Lemire, V. Curran, T. Ungar. College of Family Physicians of Canada, Mississauga, Ont., Memorial University, St. John's, NL, North York General Hospital, Toronto, Ont.}

E-learning technologies (e.g., tele- and web-seminar, and vodcasting) have shaped new educational opportunities and can transport programs to major health centers and rural communities within and across national and international boundaries. This project is based on the Education Toolkit developed by the Canadian Collaborative Mental Health Initiative. The project purpose was to bring together mental health and primary health care providers, consumers, family members, and caregivers to learn from, with and about each other, in order to enhance collaboration, for the purpose of improving the quality of care provided to people seeking mental health services in primary health care settings in Canada. This session will present the key outcomes from our CE accredited learning programs, lessons learned from using E-learning 
technologies, and recommendations for improving programs in the future. Our CE accredited 'Train-thetrainer' model, implemented using web-seminars, will form the framework for the session. Participants will have an opportunity to benefit from our lessons learned, while actually participating in a live version of our Train-The-Trainer program. This interprofessional education program has been submitted for $\mathrm{CE}$ accreditation for family physicians, pharmacists, psychiatrists and psychologist.

At the end of this session, participants will be able to: identify if E-Learning technologies are right for their interprofessional education program; create strategies to improve and enhance current E-Learning interprofessional education programs; and implement an interprofessional education program for collaborative mental health care teams in primary health care settings.

This session is relevant for educators, experienced students, consumers, family members, caregivers, and a broad range of primary and mental health care providers, including: family physicians, psychiatrists, psychologists, pharmacists, occupational therapists, dietitians, nurses (nurse practitioners, registered nurses, psychiatric nurses, mental health nurses) and social workers.

Curran V, Ungar T, Pauzé E. (2006). Strengthening collaboration through interprofessional education: A resource for collaborative mental health care educators. Mississauga, ON: Canadian Collaborative Mental Health Initiative; February 2006.

McVicar J, Deacon D, Curran V, Cornish P. (2005). Interprofessional education initiatives in collaborative mental health care. Mississauga, ON: Canadian Collaborative Mental Health Initiative; July 2005.

Oandasan I, Reeves S. (2005). Key elements for interprofessional education. Part 1: the learner, the educator and the learning context. Journal of Interprofessional Care, Supplement 1: 21-38.

\section{SIGN-UP SESSION \#126}

\section{Facilitating multi-source feedback for self- assessment and practice improvement}

\section{J. Sargeant. Dalhousie University, Halifax, NS.}

Accurate self-assessment appears to be a daunting task. Recent reviews of self-assessment studies suggest that self-assessment undertaken as an individually conducted activity often has little accuracy or reliability, peer assessment may be more accurate, and multisource feedback (MSF) may inform self-assessment. In light of these findings, the term "directed" selfassessment is proposed to highlight the need for guidance and facilitation in using and reflecting upon external sources to inform self-assessment.

The purpose of this seminar is to explore how multi-source feedback; i.e., formal feedback from peers, co-workers and patients, can inform selfassessment and practice improvement, and how these processes can be facilitated. Seminar objectives include that participants will be able to: identify factors and external resources which influence selfassessment, using multi-source feedback as a model; describe how practice context and medical culture influence self-assessment; identify activities included within multi-source feedback, self-assessment and reflection, which are amenable to educational intervention; describe how these activities might be facilitated and supported.

This will be an interactive session which will include brief presentations on the evidence related to self-assessment and multi-source feedback, and engage participants in discussions and case studies using sample MSF reports to illustrate influences upon selfassessment and facilitative approaches to support selfassessment and practice improvement.

Eva KW, Regehr G. Self-assessment in the health professions: a reformulation and research agenda. Acad Med. 2005;80(10 suppl):S46-S54.

Davis DA, Mazmanian PE, Fordis M, Harrison VR, Thorpe KE, Perrier L. Accuracy of physician selfassessment compared with observed measures of competence: a systematic review. JAMA. 2006;296:1094-102.

Sargeant J, Mann K, van der Vleuten C, Metsemakers J. Self-assessment within a social context: What have we learned from multi-source feedback? (abstract) In press. J Cont Educ Health Prof. 


\section{SYMPOSIUM \#127}

\section{Medical specialization - the good, the bad and the inevitable}

D. Gilchrist, C.P.W. Warren, G. Weisz. University of Alberta, Edmonton, Alta., University of Manitoba, Winnipeg, Man., McGill University, Montréal, Qué.

The dynamic between specialization and generalization in medicine is not a new concept. Even in the time of the ancients, some physicians were better known as diagnosticians, others for their physic. And, there have always been alternative care-givers such as barber-surgeons and midwives. As advances accumulated in knowledge and technology, some physicians naturally gravitated to the role of "specialist" while others continued to concern themselves with the entire range of medical care required by their patients.

At the beginning of the $20^{\text {th }}$ Century, a major change in medical education was recommended by the Flexner report. From multiple venues, some no better than street-front apprenticeships, medical education became firmly entrenched in universities. And, the major teachers of medicine committed to geographic full time appointments.

The $20^{\text {th }}$ Century saw a massive movement from most physicians being generalists, to a significant number being specialists and sub-specialists. Many forces have moulded this development, from within the medical profession and from outside forces such as government and public demand. The interaction between specialist and generalist has been beneficial to both sides, but also a source of conflict.

This historical look at medical specialization will give the audience an overview of the distant history of this phenomenon and a closer look at the influences of the $20^{\text {th }}$ Century.
SIGN-UP SESSION \#128

The impact of patient- and family-centered care on medical care and specialty medicine: Education Effective communications and models of care

\author{
W. Moore, V. Robinson, M. Williams, M. Cliatt. Medi- \\ cal College of Georgia, Center for Patient and \\ Family Centered Care, Augusta, GA.
}

Health care delivery has become more complex as technological advances and external pressures have increased over the past twenty years. The health care industry is frequently compared to the airline and nuclear power industries based upon the narrow operational margins that exist for safe and reliable operation.

Patients find it increasingly more difficult in navigating the system of health care. Risks for patients in the current health care system have increased. There is an increasing emphasis on teamwork and recognition of the need for skill sets that incorporate improved communication and collaboration among all members of the health care team. The Institute of Medicine laid out a framework for a new health system in the $21^{\text {st }}$ Century incorporating patient safety, patientcenteredness, effectiveness, efficiency, timeliness and equity as its six aims to improve health care. The addition of the patient and their family members to the health care team is essential to achieving the aims of the Institute of Medicine defined in Crossing the Quality Chasm: A New Health System for the 21 st Century.

Patient- and family-centered care principles need to be incorporated into the current culture of health care in order to achieve the goals of quality and safer health care for patients. The reorientation of the education of current health care professionals through faculty development programs and the education future health care professionals through incorporation of these principles into the graduate medical education process are both vital to the success of medicine in the $21^{\text {st }}$ Century.

Institute of Medicine, Committee on Health Care in America. Crossing the Quality Chasm: A New Health Sys- 
tem for the $21^{\text {st }}$ Century. Washington (DC): National Academy Press; 2001.

Gertels M, et al. Through the Patient's Eyes: Understanding and Promoting Patient-Centered Care. San Francisco, CA: Jossey-Bass Publishers; 1993.

Johnson B. Family-centered care: Four decades of progress. Families, Systems and Health. 18(2), 133-156, 2000.

SIGN-UP SESSION \#129

\section{A structured audit tool: Linking clinical practice, quality initiatives and continuing professional de- velopment}

D. Wooster. University of Toronto, Toronto, Ont.

Audit tools are helpful to objectively define performance gaps in clinical practice. The aim of this study was to develop a structured audit tool of vascular ultrasound interpretation reports for use in patient care quality assurance, objective scoring of clinical practice and as a self-assessment to guide educational initiatives.

An audit tool model was developed using reporting standards for vascular ultrasound interpretations, as collated from societies, accreditation and standards sources. The various domains of the report were identified. Specific criteria were established to assess the adequacy of the report. An objective scoring system was developed in each domain of the report and a numerical scale (1-5) was applied to each element of the audit matrix. Sixty studies from 3 different ultrasound facilities were studied in each reporting area (carotid, arterial and venous). The relevance, consistency, reproducibility and ease of use of the tool were determined. Its applicability to self-assessment, educational planning and patient care were scored by a Liekert scale and measures of the efficacy of the tool were tabulated.

The audit tool was highly rated for relevance (92\%), consistency (82\%), reproducibility (88\%) and ease of use (92\%). Objective numerical scores were obtained $(100 \%)$. It was useful for self-assessment $(100 \%)$, education $(100 \%)$ and patient care issues $(82 \%)$. Considerable variation was noted in reports and quantified with the audit tool. Specific, previously unrecognized, issues were identified and used to guide educational strategies.

It is proposed to use this audit tool as a model to discuss development of audit tools, objective scoring systems in audits and their application to improving clinical care through continuing professional development.

\section{SIGN-UP SESSION \#130 \\ integrating assessment into the postgraduate workplace: An interactive workshop}

D.J. Davis. Ottawa, Ont.

Many current assessment tools in medical education are based on a scholastic model in which learners demonstrate their knowledge and skills in written examinations and checklists during simulated sessions. As well, clinical rotation evaluations are used to assess learners but have been shown in some studies to be inflated and subject to "the halo effect". Further, much of medical education takes place in the workplace. Tools to assess authentic workplace activity are needed. Because assessment drives learning, it is important to integrate work-based learning and assessment in a valid and reliable way. Furthermore, competence is multidimensional and assessment tools should be designed to capture this. Tools should assess not only the traditional medical expert role, but should also include the desired outcomes within the other roles of the CanMEDS framework wherever possible. Because assessment drives learning, it can be appropriate to include assessment tools for both activities that are common and for activities that learners find challenging but are essential to the workplace. The development of such tools is best done with input from a variety of stakeholders. Those developing the tools must have a very clear idea of the tasks learners are expected to be able to perform, the expected standard for the performance, and the context in which learners should be able to do these tasks. Data from quality assurance studies can also be used to foster development of tools for learning and assessment. Studies have documented that these types of tools have an effect on learning and the educational envi- 
ronment. During this workshop the design and implementation of such tools will be discussed. Examples will be given from several different specialties in which such tools have been created.

Ringsted C, Skaarup AM, Henriksen AH, Davis DJ. Person-task-context: a model for designing curriculum and in-training assessment in postgraduate education.

Med Teach. 2006 Feb; 28:70-6.

Ringsted C, Østergaard D, van der Vleuten CPM. Implementation of a formal in-training assessment programme in anaesthesiology and preliminary results of acceptability. Acta Anaesth Scand 2003; 47: 1196-203.

Ringsted C, Østergaard D, Scherpbier A. Embracing the new paradigm of assessment in residency training. An assessment programme for first year residency training in anaesthesiology. Med Teach 2003; 25: 54-62.

\section{SIGN-UP SESSION \#131}

\section{Destination: CanMEDS communicator - using Martin's Map to guide the teaching and learning of communication competencies}

\section{Martin, S. Glover Takahashi. University of Toronto, Postgraduate Department of Medical Education, Toronto, Ont.}

This paper is a case study reporting how a communication tool has been used to help International Medical Graduates and Postgraduate medical doctors learn many of the communication competencies outlined by CanMEDS. Residents often have difficulty knowing how to use what they know using a patient-centered approach. Being patient-centered is often interpreted by doctors to mean handing over complete control to the patient or inquiring about the patient's social history. Martin's Map is a flexible tool for both teaching and learning how to integrate a patient-centered approach into the medical interview regardless of the learner's ability, the patient's problem(s) and whether it is a first or subsequent office visit. Medical interviews are not haphazard events, they have structure and organization. The Map visually outlines the framework of the clinical encounter enabling doctors to better understand that good interviews have an opening (patient's illness experience and agenda set- ting), a middle (data collection) and an end (treatment and management plan). Doctors can conceptualize the medical interview so they better understand how to organize their medical knowledge using a patientcentered approach, while providing supervisors with a standardized tool for offering practical and relevant feedback about both content and process.

This paper describes how the Map has been used to construct communication curricula that can be used across the medical specialties to help residents better understand how to practically integrate the CanMEDS communicator role into their everyday practice.

Martin D. Martin's Map: a conceptual framework for teaching and learning the medical interview using a patient-centered approach. Medical Education 2003; 37:1145-1153.

Kurtz S, Silverman J, Draper J. Teaching and Learning Communication Skills in Medicine, $2^{\text {nd }}$ edition (2005) Radcliffe Publishing: Oxford and San Francisco

Silverman J, Kurtz S, Draper J. Skills for Communicating with Patients, $2^{\text {nd }}$ edition (2005) Radcliffe Publishing: Oxford and San Francisco.

\section{SIGN-UP SESSION \#132}

\section{Beyond headlines: De-coding the public-private debate for Canadian specialists}

\section{R. McMurtry, T. Noseworthy. University of Western Ontario, London, Ont., University of Calgary, Cal- gary, Alta.}

This session is designed to help physicians and surgeons understand the evidence, policy, and politics at the core of the debate over Canada's health care system. As health care systems evolve across Canada, new models of financing and delivery are being explored. How can we assess whether these are good for our patients? What should the Canadian system look like in the $21^{\text {st }}$ Century? By defining terms, exploring challenges, and analyzing international alternatives, participants will learn to de-code articles in the lay press, understand international policy comparisons, and participate in the debate.

Session outline includes: 1) a general overview and definition of terms, e.g. public versus private, finance versus delivery, along with an overview of the 
health system structure in Canada; 2) "Walk around the Globe" - an international comparison exercise that situates Canada in an evidence-based context with regards to the financing and delivery of health care; 3 ) Analysis of media coverage - with participants analyzing sample articles to determine bias; 4) Group discussion on delivery models - with participants considering different care models and their impact on specialty care providers, patients and medical education; 5) The role of the specialist - with an overview and discussion of the potential role of Canadian physicians in the debate.

\section{SIGN-UP SESSION \#133}

\section{Extended uses of formal self-assessment modules in continuing professional development (CPD)}

D. Wooster, B. Capusten, R. Sidhu. University of Toronto, Toronto, Ont., University of Calgary, Calgary, Alta., University of British Columbia, Vancouver, BC.

The aims of this session are to provide an inventory of extended uses of self-assessment modules in identifying unperceived learning needs; to discuss these approaches in group learning activities; and, to explore innovative outcomes of such activities.

Self-assessment programs (SAPs) are traditionally presented as comprehensive stand-alone programs. Experience with the Vascular Self-Evaluation Program has shown its value as a means of identifying unrecognized needs and providing quantified guidance to subsequent CPD activities on an individual basis. In addition, specialty societies can use this format as a global needs assessment for planning educational products. Modules from this program have been used in group learning situations to ground discussions, focus learners' attention and act as a basis for formal presentations. We have used audience response systems, informal 'polls' and paper-based responses to engage the learners and provide feedback to presenters. Outcomes from the use of such modules include modification of the group learning activity 'on-therun', objective documentation for future presentations, focused individual learning and a high level of learner engagement and satisfaction with the learning experience.

Specific examples of extended uses of SAPs will be given with discussion by the panel and the participants. The use of SAP modules and types of interactions in small and large group learning activities will be illustrated. Outcomes for the program and for the participants will be discussed. Participants will be able to discuss ways to utilize the concepts in their own setting, both personally and on a society basis.

\section{SIGN-UP SESSION \#134}

\section{Selecting the best residents for your program}

\section{G. Bandiera, G. Regehr. University of Toronto, Wil- son Centre for Research in Education, Toronto, Ont.}

There are many challenges to designing an appropriate applicant selection process for residency programs. Applicant pools are becoming more heterogeneous; the expectations for training are more precise, competency-based and specialty-specific; and programs are defining their own social accountabilities more precisely. All of these increase the imperative to select residents that are the best match to what a program has to offer and what it is trying to do. In this session, we will discuss the theory behind proper selection processes and highlight several important pitfalls to be aware of. We will then ask participants to work in small groups to identify key priorities for their program, seek out sources of evidence for candidate attributes, and design selection or ranking tools for their applicants. In the ensuing discussion, we will discuss reliability and validity as they pertain to resident selection, design considerations for application assessments and interview format, and appropriate training for selection committee members. Participants will leave the session with a knowledge of supporting literature and a list of resources to allow them to select residents with confidence for their programs.

Bandiera G, Regehr G. A structured application assessment instrument is a reliable tool for assessing applications to Canadian postgraduate training programs in Emergency Medicine. Acad Emerg Med. 2003 10: 594-598. 
Bandiera GW, Regehr, G. Reliability of a Structured Interview Scoring Instrument for a Canadian Postgraduate Emergency Medicine Training Program. Acad Emerg Med. 2004;11(1):1 27-32.

\section{SIGN-UP SESSION \#137}

\section{Debate: The future of generalism in medicine}

\section{J. Frank, J. Nagle, R. Ramsaran, D. Danoff, P. Rains-} berry. The Royal College of Physicians and Surgeons of Canada, Ottawa, Ont., The College of Family Physicians of Canada, Mississauga, Ont.

Does Canada need more "generalists"? Does the Canadian postgraduate medical education system promote enough "generalism"? Is it important that medical education follow a logical progression from breadth to depth? Do subspecialists or generalists provide better care for some illnesses?

Many Canadian medical leaders disagree on the level of "generalism" that is required for an effective and efficient postgraduate medical curriculum. Some have argued that the Royal College should increase the foundational training by reducing the number of entry points into postgraduate medical education. Others have stressed the contrary, because of the amount of technological advances and the excessive length of training of postgraduate medical education, the amount of generalism should be decreased or maintained to ensure a high level of expertise for specialists.

This debate will seek to define the nature and importance of "generalism" for the future of postgraduate medical education and determine how best to ensure an appropriate amount of broad-based training at the postgraduate level. Participants and panel members will be engaged to come up with recommendations for the Colleges.

Participants will be able to define "generalism" in medicine; describe some of the controversies related to "generalism"; describe some future policy options regarding "generalism" in Canadian medical education.

Carraccio C, Wolfsthal SD, Englander R, Ferentz K, Martin C. Shifting Paradigms: From Flexner to Competen- cies, Academic Medicine, Volume 77, Issue 5, 361-367, 2002.

Bulger RJ. Generalism and the need for health professional educational reform, Academic Medicine, Volume 70, Issue 1, 31-34, 1995.

Ebert RH. Flexner's Model and the Future of Medical Education. Academic Medicine, 67, 737-742. 1992.

\section{SIGN-UP SESSION \#138}

\section{The future of postgraduate medical education: Op- timizing career choice in medicine}

J. Frank, J. Nagle, R. Ramsaran, D. Danoff, P. Rainsberry The Royal College of Physicians and Surgeons of Canada, Ottawa, Ont., The College of Family Physicians of Canada, Mississauga, Ont.

How do physicians choose their career disciplines?

It has been argued through several reports and position papers of working groups, task forces and resident and medical student organizations, that the career decision making process for medical students is not optimally designed. Some believe that medical students are faced with premature career choice in medical school due to the timing and competitive nature of the CaRMS matching process. This could compromise their exposure to a broad range of disciplines and may further impact physician career satisfaction.

This session will explore the following questions: does the current medical school environment and matching process influence early career decision making? If so, does early career decision making adversely impact student career choice? Would this have a long-term effect on physician career satisfaction?

Research on career choice found certain variables such as the medical school environment, educational debt and the 'hidden' curriculum, to either promote or disfavor medical students' attitude towards a discipline through the amount of clinical exposure, elective offerings, curriculum, mentoring that takes place. The data also suggests that this is largely a Canadian concern.

This session will provide options and recommendations for consideration by the national Colleges, Canadian medical faculties and leaders in medical education, for their deliberation. 
Participants will be able to define "premature career decision making" in medicine; describe some of the trends in medical student career choice in Canada; describe some future directions for Canadian medical education with respect to physician career choice.

Schafer S, et al. Is Medical School the right place to choose a specialty? Journal of the American Medical Association 2001; 285: 2782-2783.

Dobson B. Choosing a career: the undergraduate dilemma. Medical Teacher. Volume 8, Issue 1, 1986.

Harvey J, et al. Trends in disciplines selected by applicants in the Canadian residents matches, 1994-2004. Canadian Medical Association Journal. Volume 172, Issue 6, 2005.

\section{SIGN-UP SESSION \#139}

\section{The future of postgraduate medical education: Flexibility and switching careers in medicine}

J. Frank, J. Nagle, R. Ramsaran, P. Rainsberry. The Royal College of Physicians and Surgeons of Canada, Ottawa, Ont., The College of Family Physicians of Canada, Mississauga, Ont.

Are the perceived inflexibilities in residency training real or myth? If real, how do we go about improving the system to allow for increased flexibility? What are some of the reasons that may deter residents and physicians from changing career paths? How does the system's flexibility impact the future physician's career satisfaction?

The perception is that the current structure of the postgraduate medical education system impedes residents' ability to change their specialty (switching) and physicians to change career paths (re-entry). This session will explore these two areas with the following objective: to assess and analyze the extent of the constraints faced by residents and physicians in switching career paths.

Research has shown that while all schools have reentry frameworks and/or policies in place, the number of re-entry trainees has consistently declined since the end of the rotating internship, that there is a lack of consistency across Canada in the provision of dedicated re-entry positions and that physicians who are accepted into re-entry programs are normally expected to complete a return-to-service agreement in an underserviced area as identified by their provincial Ministry of Health. The capacity of the system may also be a significant consideration to residents who seek to switch specialties.

This session will explore the current state of switching and re-entry constraints and propose recommendations for further action by the Colleges'.

Participants will be able to define "re-entry' and "flexibility" in Canadian medical education; describe the patterns and trends in physician career changes over the last decade; describe some possible future directions for Canadian medical education to enhance career flexibility.

Dauphinee D, Thurber D. What are the facts concerning the number of residency positions in Canada? Canadian Medical Association Journal, 1997; 156: 665-7.

CMA News. Re-entry to training: "Please, just open the door a crack". CMA Second National Invitational Conference on Flexibility in Career Choice in Medicine. CMA News. Volume 2, Issue 4, 1999.

Canadian Medical Association. Major changes in residency training on horizon. Canadian Medical Association Bulletin. Volume 172, Issue 4, 2005.

\section{SIGN-UP SESSION \#140}

\section{The future of postgraduate medical education: The} structure of residency education in the $21^{\text {st }}$ century

\section{J. Frank, J. Nagle, R. Ramsaran, D. Danoff, P. Rains-}

berry. The Royal College of Physicians and Surgeons of Canada, Ottawa, Ont., The College of Family Physicians of Canada, Mississauga, Ont.

In order for medical education to respond to changing scientific, technological and societal demographic conditions it must continually reconfigure itself. This has been even more parent with the significant and dramatic growth in the number of disciplines recognized by the Royal College. Currently, the Royal College recognizes 28 specialties and 33 subspecialties. For many this is a far too dramatic growth that signifies an overly fragmented medical and superspecialized system that does not allow residents to attain a sufficiently broad-based knowledge, skills, and 
attitudes that can be maintained throughout their careers.

Medical leaders including undergraduate and postgraduate deans across Canada have also identified a large number of PGY-1 entry points as an issue of concern that impacts the quality of education and have therefore urged the Royal College to decrease the number of entry points significantly.

Professionals in training should be equipped with the knowledge, skills and resources to meet societal health needs. This session will explore the issues identified above as well as the feasibility of redesigning the structure of Canada's postgraduate medical education system to provide the Colleges with a course of action.

Participants will be able to describe recurring issues in the structure of Canadian postgraduate medical education (PGME); describe the pros and cons for proposals to change the PGME system; define one possible new direction for the structure of residency education in Canada in the coming years.

Canadian Medical Forum. Report of the Working Group on the Common PGY-1. Co-Chairs: Verma S, Clarke J. Approved by the Canadian Medical Forum for Discussion, June 2004.

The Royal College of Physicians and Surgeons of Canada. (1996). A Re-examination of the Royal College Specialties and Subspecialties, 'The Langer Report'.

The Royal College of Physicians and Surgeons of Canada. (1996). Final Report of the Task Force to Review Fundamental Issues in Specialty Education, 'The Maudsley Report' April 1996.

\section{SIGN-UP SESSION \#141}

\section{Beyond the medical expert role: New opportunities for self-assessment programs}

\section{G. Wallace, S. Swiggum, T. Gondocz. The Canadian Medical Protective Association, Ottawa, Ont.}

The development of accredited self-assessment programs (SAPs) outside the Medical Expert Role can be challenging for medical organizations wishing to provide such educational products to members. Using the criteria provided by the Royal College of Physicians and Surgeons of Canada (RCPSC), the Canadian
Medical Protective Association (CMPA) developed five online learning modules for recognition under Section 3 of the MOC program. These modules focus on the CanMEDS roles of Communicator, Professional, and Manager.

To gain and maintain any CanMEDS competency, practicing physicians and trainees must be able to recognize their deficiencies. In addition to understanding one's own knowledge and deficiencies, guided feedback from experts is required to address these. Thus, one criteria for recognition as an accredited SAP is the provision of learner feedback that identifies gaps in knowledge and provides learners with guidance to filling those gaps.

For SAPs, the educational methods used by the CMPA incorporate risk management strategies, casebased learning, and interactivity. At the end, a ten question self-assessment quiz provides the learner with online feedback regarding learning gaps and resources to address these gaps. The CMPA selfassessment exercise then connects the learner to the development of a learning plan.

The CMPA's approach to creating an online learning environment included releasing the modules without the self-assessment component in order to gain experience with online learning.

Duffy FD, Holmboe ES. Self-assessment in lifelong learning and improving performance in practice: Physician know thyself. JAMA 2006;296(9):1137-9.

The Royal College of Physicians and Surgeons of Canada. Maintenance of Certification (MOC) Program Guide. Ottawa, Ont., 2006.

The Royal College of Physicians and Surgeons of Canada. Accredited Self-Assessment Programs (SAPs) located online http://rcpsc.medical.org/opd/mainport/index. php\#self-assess (accessed June 15, 2007). 


\section{Royal College Abstracts}

\section{BEST PRACTICES AND INNOVATIONS IN CAN- MEDS EDUCATION - PratiQues EXEM- PLAIRES DANS L'ENSEIGNEMENT DES COMPÉTENCES CANMEDS (1-10)}

\section{Communication skills training on orthopaedics}

\section{K. Lundine, J. Lockyer, C. Hutchison, R. Buckley.} University of Calgary, Calgary, Alta.

Communication skills have been identified as a key component of medical education by the CanMEDS Project. The objectives of this study were to identify the perceived key components of communication skills from the perspectives of both orthopaedic residents and their program directors, and to understand how these skills are currently taught.

This study utilized a mixed methods design. Quantitative data was collected using a 30-item questionnaire, which was distributed to all Canadian orthopaedic residents. Qualitative data was collected through focus groups with orthopaedic residents and semistructured interviews with orthopaedic program directors.

One hundred and nineteen out of three hundred and twenty-five questionnaires were completed (response rate $=37 \%$ ), twelve residents participated in two focus groups, and 9/16 program directors from across the country were interviewed. The questionnaire reliability had an internal consistency of Cronbach's alpha $=0.72$. An ANOVA of the questionnaire data showed gender and International vs. Canadian medical graduate status to be independent variables to several item responses $(\mathrm{P}<0.01)$. The factor analysis produced a five-factor model accounting for $50 \%$ of the variance.

Both program directors and residents identified communication skills as being the accurate and appropriate use of language (ie, content skills), not how the communication was presented (ie, process skills).
Perceived barriers to communication included time constraints and the need to adapt to the many personalities and types of people encountered daily in the hospital. Residents lack explicit communication skill training, but value developing communication skills in the clinical environment through experiential learning and role modeling. Resident education should focus on developing residents' process skills in communication. Care should be taken to avoid large-group didactic teaching sessions, which are perceived as ineffective.

\section{Use of a health advocacy essay to improve com- petence}

\section{Borgaonkar, D. Pace, P. Jeon. Memorial University of Newfoundland, St. John's, NL.}

We set out to determine if essay writing on health advocacy could improve scores on a Health Advocacy observed structured clinical exam (OSCE) station.

A Health Advocacy station was used as one of ten stations at the annual resident OSCE in 2006. Subsequently, residents were instructed to write an essay regarding their actions as a health advocate, either in general or relating to a specific situation. For the 2007 OSCE, a different Health Advocacy station was used that was similar to the previous year in terms of the issues that residents needed to address and the scoring structure. The results on the OSCE stations between the two years were compared using Student's T-test. Regression analysis was used to identify any predictors for a higher score.

The number of residents taking the OSCE in 2006 and 2007 were 17 and 13, respectively. Nine residents completed the OSCE in both years. The number of PGY-1's taking the OSCE for the first time in 2006 and 2007 were 8 and 4, respectively. Compliance with the essay writing was $100 \%$. The mean score on the Health Advocacy station was significantly higher in 2007 compared to 2006 (53.0 \pm 14.6 compared to 65.6 \pm 10.0 vs. $53.0 \pm 14.6$; $=0.01)$. The mean score of PGY-1's in 2007 tended to be higher than PGY-1's in 2006 (67.5 \pm 11.4 vs. $54.5 \pm 12.3 ; \mathrm{p}=0.11)$, suggesting the improvement was not due to having taken the 
OSCE previously. Regression analysis did not identify and other predictors of higher score on the OSCE station.

These results suggest that essay writing by residents about actions they have taken as health advocates improves knowledge about the CanMEDS competency of Health Advocacy, as measured in an OSCE station. The non-randomized design of the study does not exclude the possibility of other factors influencing the improvement in score.

Oandasan I, Barker K. Educating for Advocacy: Exploring the Source and Substance of CommunityResponsive Physicians. Acad Med 2003; 78(1):S16-S19.

Frank J, Langer B. Collaboration, Communication, Management, and Advocacy: Teaching surgeons new skills through the CanMEDS project. World J Surg 2003; 27:972-978.

Verma S, Flynn L, Seguin R. Faculty's and residents' perceptions of teaching and evaluating the role of health advocate: A study at one Canadian university. Acad Med 2005; 80:103-108.

\section{3. interactive online software documenting and corroborating exposure to CanMEDS roles}

Y. Lamarche, L.P. Perrault, G. Beauchamp, J.-F. Renaud, S. Lamarche, M. Carrier. Institut de cardiologie de Montréal, Université de Montréal, Montréal, Qué.

Residents are exposed to various situations contributing to the development of their CanMEDS roles. Exposure to different clinical scenarios and teaching situations contributing to the development of the CanMEDS roles could be identified, documented by residents and corroborated by staff supervisors retrospectively. A rapid and thorough method to assess this exposure is not available and could help to monitor a programs strengths and weaknesses.

Daily activities developing specific CanMEDS roles where identified initially by the program director and residents. An internet based automatic survey generator (residentevaluation.com) was built to interrogate residents on a weekly basis on their exposure these clinical activities, linked to the seven CanMEDS roles. The surveys where automatically directed to supervisors for corroboration and comments. Periodic and annual reports where sent to the program director.

The study group was composed of the Université de Montréal cardiac surgical trainees $(n=6)$. Weekly surveys were sent from July 2006 to March 2007 (Ongoing). Participation rose from $42 \%$ to $79 \%$ in trainees and was $70 \%$ among supervisors. Time to fill the weekly survey was less than 1 minute for trainees and supervisors. The majority of residents documented development of all seven CanMEDS roles on a weekly basis. The trainees were exposed on a weekly basis to a reflection on the development of their CanMEDS competences.

Cardiac surgical trainees at Université de Montréal are exposed and develop their CanMEDS roles over their regular training. The residentevaluation.com program allows a rapid weekly assessment and documentation of exposure to CanMEDS roles. The tool provides periodic and annual reports for program directors to quantify this exposure and adjust the program objectives. This software could be used in other programs to assess its efficiency in different cohorts.

Frank, JR, ed. 2005. The CanMEDS 2005 physician competency framework. Better standards. Better physicians. Better care. Ottawa: The Royal College of Physicians and Surgeons of Canada

Frank JR, Jabbour M, Fréchette D, Marks M, Valk N, Bourgeois G, eds. Report of the CanMEDS Phase IV Working Groups. Ottawa: The Royal College of Physicians and Surgeons of Canada. March, 2005.

\section{Leadership in postgraduate medicine: Results from the first annual chief resident leadership workshop.}

S. Verma, R. Zulla, J. Mikhael, A. Natsheh, S.G. Takahashi, L. Muharuma and J. McIlory. Postgraduate Medical Education Office, Department of Medicine, Faculty of Medicine, University of Toronto, Professional Association of Residents and Internes of Ontario, Toronto, Ont.

In the spring of 2006, chief and senior residents were surveyed to determine how they prepared for their senior administrative/leadership role, what topics 
should be included in a leadership workshop and how this workshop should be delivered. Overall, 32.3\% had no prior contact with the previous chief resident. Among those prepared, $46 \%$ consulted previous chiefs/seniors and/or program directors. Eighty-five percent agreed that a leadership workshop would be beneficial for future chiefs.

Using the results from this environmental scan, a planning committee was formed to design the First Annual Chief Resident Leadership Workshop, held in August 2006, to identify and develop leadership skills while providing them with the resources to ease their transition into this senior administrative role. Seven sessions were offered: Your Role as Chief Resident, Mentorship, overview of the residents' work/ education contract, Personality Inventory (i.e. MyersBriggs), Anti-Racism and Harassment, Resident Wellness and Public Speaking. A keynote address on leadership in academic medicine was given by a wellknown Canadian clinician leader. To reinforce the experience, a resource binder and handbook was distributed to all participants.

Quality and content of each session was evaluated using on a 5-point Likert scale. Mean scores were calculated. Mentorship scored the highest in terms of quality (4.46) and content (4.47), followed by Leadership in Academic Medicine (4.43 and 4.62, respectively). Over $90 \%$ agreed that a leadership program is necessary. Parallel to our earlier findings, many chief residents use multiple sources to prepare for their role, primarily the pairing of contact with the previous chief resident and the Program Director. The results indicate that a formal, centralized leadership workshop/seminar is valued and should highlight the necessary skills set and provide key resources.

Susman J, Gilbert C. Family practice residency directors' perceptions of the position of chief resident. Academic Medicine 1992; 67(3):212-213.

Awad JJ, Levenson SM, Osman CH, James S. The impact of a novel resident leadership training curriculum. The American Journal of Surgery 2004; 188:481-484.

Kasuya RT, Nip IL. A retreat on leadership skills for residents. Academic Medicine 2001; 76(5):554.

\section{A needs assessment for a CanMEDS-based cur- riculum in ambulatory: Care for internal medicine residents in Canada}

R. Wong, S. Roff. University of Toronto, Toronto, Ont., University of Dundee, Dundee, UK.

In Canada, graduates of internal medicine training programs should be proficient in ambulatory medicine and practice. Before determining how to improve education in ambulatory care, a list of desired learning outcomes must be identified and used as the foundation for the design, implementation and evaluation of instructional events. The Delphi technique is a qualitative-research method that uses a series of questionnaires sent to a group of experts with controlled feedback provided by the researchers after each round of questions. A modified Delphi technique was used to determine the competencies required for an ambulatory care curriculum based on the CanMEDS roles.

Four groups deemed to be critical stakeholders in residency education were invited to take part in this study: 1. Medical educators and planners, 2. Members of the Canadian Society of Internal Medicine (CSIM), 3. Recent Royal College certificants in internal medicine, 4. Residents currently in core internal medicine residency programs. Panelists were sent questionnaires asking them to rate learning outcomes based on their importance to residency training in ambulatory care. Four hundred and nineteen participants completed the round 1 questionnaire that was comprised of 75 topics identified through a literature search. Using predefined criteria for degree of importance and consensus, 19 items were included in the compendium and 9 were excluded after one round. Forty-two items for which the panel that did not reach consensus, as well as 3 new items suggested by the panel were included in the questionnaire for round 2. Two hundred and forty participants completed the round 2 questionnaire; consensus was reached for each of the 45 items.

After two rounds, 21 items were included in the final compendium as very high priority topics ("must be able to"). An additional 26 items were identified as high priority topics ("should be able to"). The overall 
ratings by each of the four groups were similar and there were no differences between groups that affected the selection of items for the final compendium. To our knowledge this is the first time a Delphi-process has been used to determine the content of an ambulatory care curriculum in internal medicine in Canada. The compendium could potentially be used as the basis to structure training programs in ambulatory care.

Barker LR. Curriculum for Ambulatory Care Training in Medical residency: rationale, attitudes and generic proficiencies. J Gen Intern Med 1990; 5(supp.):S3-S14.

Levinsky NG. A survey of changes in the proportions of ambulatory training in internal medicine clerkships and residencies from 1986-87 to 1996-97. Acad Med 1998; 73:1114-1115.

Linn LS, Brook RH, Clarke VA, Fink A, Kosecoff J. Evaluation of ambulatory care training by graduates of internal medicine residencies. J Med Educ 1986; 61:293-302.

\section{CanMEDisification: The role of postgraduate medicine office in supporting the learning and teaching of CanMEDs roles}

S.G. Takahashi, S. Verma, L. Muharuma, R. Zulla. Postgraduate Medical Education, Faculty of Medicine, University of Toronto, Toronto, Ont.

The Postgraduate Medical Education Office at the University of Toronto has implemented a range of faculty development initiatives targeted at supporting the full implementation of CanMEDS roles and competencies in the day to day learning, teaching and evaluation of residents across the highly distributed postgraduate medicine training programs. In October 2005, the Royal College of Physicians and Surgeons of Canada (RCPSC) released a revised version of the CanMEDS roles. In June 2006, the RCPSC accreditation standards for postgraduate medicine changed some standards which result in an increased expectation of implementation of the CanMEDS roles in teaching and evaluation of residency programs.

From 2005 to 2007, there have been numerous initiatives by the Postgraduate Medical Education Office to support the understanding and implementation of the CanMEDS roles into the learning, evaluation and outcomes of postgraduate training at the
University of Toronto. The PGME Office supported the 'CanMEDSification' or integration of the CanMEDS framework by: 1) Supporting the development of teacher/faculty teaching and evaluation resources; 2) Providing faculty development in the understanding of these competencies; 3) Providing explicit program feedback through the Internal Review process

The CanMEDS roles have been widely integrated into teaching and evaluation at the University of Toronto. The high attendance rates at workshops and positive workshop evaluations indicate the value of centralized faculty development initiatives and also indicate an increasing confidence in using CanMEDS. The workshop evaluations also indicate a need for additional faculty development in evaluating the non Medical Expert roles.

Shorter E. Oxford English Dictionary (5th ed.). Oxford, UK: Oxford University Press, 2002.

Harris, IB. Deliberative inquiry: The arts of planning. in E.C. Short (ed.), Forms of curriculum inquiry. Albany: State University of New York Press, 1991; 285-307.

Harris, IB. New expectations for professional competence. In L. Curry \& J. F. Wergin (Eds.), Educating professionals: Responding to new expectations for competence and accountability. San Francisco: Jossey-Bass, 1993; 1752.

\section{Présentation d'un portfolio électronique pour la formation et l'évaluation des compétences Can- MEDS en obstétrique-gynécologie}

\section{M.-J. Dupuis, D. Girardot. Université de Montréal, Montréal, Qué.}

Bien que les objectifs d'apprentissage et fiches d'évaluation de stage tiennent compte des sept compétences CanMEDS, il est difficile d'intégrer celles ci dans l'apprentissage et l'évaluation. Le portfolio, lorsque utilisé dans une approche réflexive, favorise l'apprentissage des compétences. Le développement et l'utilisation du portfolio visent une meilleure intégration des rôles CanMEDS dans l'apprentissage et une évaluation authentique des compétences.

Notre programme adopte le portfolio comme outil d'apprentissage et d'évaluation. Pour chaque compétence CanMEDS, le portfolio comprend 6 sections : 1) 
Critères spécifiques pour la compétence, 2) Description par le résident d'une bonne et d'une mauvaise performance, 3) Description d'un incident critique (un par année) ayant transformé sa formation, 4) Auto évaluation, 5) Rétroaction.

A chaque trimestre, le résident rencontre son tuteur et présente son auto évaluation. Celle-ci est comparée à l'évaluation que les superviseurs font du résident, compilée et présentée au résident par son tuteur. Annuellement, le résident fournit la preuve de sa progression pour une compétence donnée. Pour ce faire, il complète son portfolio régulièrement en cours d'année pour documenter l'analyse de sa progression à l'aide d'exemples tirés de son portfolio.

Après une année d'implantation, nous évaluerons l'impact sur la perception de l'intégration des compétences CanMEDS aux niveaux des apprentissages et des évaluations, et le degré de satisfaction des résidents et des tuteurs.

Naccache N, Samson L, Jouquan J. Le portfolio en éducation des sciences de la santé: un outil d'apprentissage, de développement professionnel et d'évaluation. Pédagogie médicale, 2006; 7: 110-27.

Tardif J. L'évaluation des compétences: documenter le parcours de développement, 2006

Kjaer NK, Maagaard R, Wied S. Using an online portfolio in postgraduate training. Medical Teacher, 2006; 8:708-712

\section{Modelling and teaching collaboration: The in- terprofessional education in geriatric care project}

C. van Ineveld, R. Grymonpre, E. Boustcha, M. Nelson, A. Booth, A. De Jaeger, F. Jensen, T. Sullivan, J. Swinamer, L. Weinberg. University of Manitoba, Winnipeg, Man.

The Interprofessional Education in Geriatric Care (IEGC) project is an Interprofessional Education for Collaborative Patient-centred Practice Initiative (Health Canada) funded project that was launched in June 2005 and ends March 2008. The goal of the IEGC project is to develop a sustainable clinical experience that models and teaches the core concepts of patient centred collaboration (goal directedness, leadership, flexibility, team dynamics, conflict resolution, communication, and disciplinary articulation) which directly reflect the enabling competencies of the "Collaborator Role" outlined in the 2005 CanMEDS Framework.

The primary learners are Internal Medicine/Family Medicine residents and senior students in nursing, occupational therapy, physiotherapy, and pharmacy. The interprofessional education occurs at three geriatric day hospitals where collaborative patient-centred care of community dwelling older clients is the standard of practice, and clinicians traditionally accept students for clinical placements. The IEGC project identified instances that learners from two or more disciplines were at Day Hospital simultaneously for approximately three weeks. During this time, experiential learning activities emphasizing the skills needed for effective collaboration were added to typical preceptor based teaching.

Feedback early in the project from students and preceptors indicated that the original design, (practice simulations and didactic small group sessions), were not meeting clinical learning objectives. In response, the clinical teams initiated team led discussions regarding core concepts and students were given the opportunity to assess and develop care plans for "student team" designated patients. In addition structured team observations, directed readings, self-reflective exercises and "ice-breakers" are utilized. Informal feedback from participants has suggested that this is more effective, and relevant way to teach patient centred collaborative practice. The IEGC project has extensive research and evaluation methods based on the JET's modification of Kirkpatrick's Model of Educational Outcomes which will assess the effectiveness and viability of the IEGC educational approach.

The Interprofessional Joint Evaluation Team. (2002). A Critical Review of Evaluations of Interprofessional Education. http://www.health.heacademy.ac.uk/publications/ occasionalpaper/occasionalpaper02.pdf/view. Accessed September 9, 2005.

Frank JR, Jabbour M, et al. Eds. Report of the CanMEDS Phase IV Working Groups.

Ottawa: The Royal College of Physicians and Surgeons of Canada. March, 2005. 


\section{Innovation in research instruction: Pilot testing of team learning to promote peer reviewed grant- writing by clinician trainees}

\author{
F. Warnock, J. Sibley. University of British Columbia, \\ Vancouver, BC.
}

We piloted the combination of Team-Based Learning (TBL) with interactive in-class instruction in grantsmanship to test its effectiveness in preparing clinician trainees to produce a national (CIHR) peer reviewed operating grant in a small class setting. The approach was integrated into a university graduate quantitative method and design course delivered to five trainees in 12 weekly $4 \mathrm{hr}$ sessions. Outcomes to assess knowledge acquisition, retention and application included percentage scores in seven TBL individual and student team tests (each containing 15-20 multiple-choice items), student participation in a mock peer review and student own submission of an operating grant (using CIHR peer review evaluation criteria to assess methodological coherency and soundness of the research design and plan, feasibility, relevancy and innovativeness). Also assessed were student perception of the approach on their learning ( 7 item questionnaire) and two peer teaching evaluations.

In seven consecutive testing sessions, percentage scores for the individual tests were $80,72,76,71,83$, 75 and 80 and corresponding team scores were 96, 96, $83,100,95,97$, and 97 suggesting an $18 \%$ increase in individual knowledge with team testing. Overall, student achievements were $93 \%$ for mock peer review and $78 \%$ for grant production. Trainees rated TBL and the interactive in-class activities as effective in consolidating knowledge and promoting complex research design decision making. Evaluations of the teaching were 4.7 and 4.8 out of 5. Findings suggest students mastered course content, that team learning increased individual knowledge and that trainees linked theory to successfully produce a CIHR operating grant. These pilot findings call for larger prospective studies to test the combined approach in larger classes and with other populations of clinician trainees.
The clinician scientist: yesterday, today and tomorrow. Canadian Institutes of Health Research. http://www.cihr-irsc.gc.ca/e/pdf_22084.htm. Accessed February 25, 2007.

Ringel SP. Steiner JF, Vickrey BG, Spencer SS. Training clinical researchers in neurology: We must do better. Neurology 2001; 57:388-392.

Haidet P, O'Malley KJ, Boyd R. An initial experience with 'Team Learning' in medical education. Academic Medicine 2002; 77: 40-41.

\section{Designing an online curriculum supporting risk management and patient safety}

\section{S. Swiggum, T. Gondocz, G. Wallace. The Canadian Medical Protective Association, Ottawa, Ont.}

The Canadian Medical Protective Association (CMPA) is a not for profit mutual defence organization with a mandate to provide medico-legal assistance to physician members and to educate health professionals on managing risk and enhancing patient safety. To expand the outreach to its 72,000 member physicians, the CMPA built an online learning curriculum of risk management and patient safety materials in 2006. These activities are mapped to the real needs of members ensuring the activities are relevant.

Eight major categories were developed containing both online courses and articles. Each course and article is mapped to the RCPSC's CanMEDS roles and the CFPC's Four Principles.

This poster shares the CMPA's experience in designing an online patient safety curriculum within the context of medico-legal risk management and provides an inventory of materials linked to the CanMEDS roles.

Our formula for creation of an online curriculum included basing the educational content on real needs of member physicians; using case studies to teach concepts; and, monitoring and evaluating process and outcomes.

The objectives are to explain the benefits of curricular approach for course planning across the continuum in medical education; outline the utility of the CanMEDS roles in organizing the risk management and patient safety medical education curriculum; de- 
scribe the progress of CMPA's online learning system; and, outline the potential for moving the curriculum of online learning materials and resources into medical schools.

\section{Health POlicy - PolitiQue EN MATIÈRe DE LA SANTÉ (11-21)}

\section{Who is in charge? Introducing Criteria to Evaluate Health Human Resource (HHR) Policy Documents}

\section{Rosenfield, C. Abrahams, S. Verma. McMaster University, Hamilton, Ont., University of Toronto, Toronto, Ont.}

The maldistribution of and lack of access to health professionals continues to be a major issue for policymakers at all levels of government. Additionally, the basis by which Health Human Resource (HHR) policy is determined is unclear. Publications found in independent reports, peer-reviewed journals and most importantly, grey literature, can significantly influence or inform major policy decisions for "hot button" HHR issues (1). We propose a framework that can be used to classify, rank and evaluate HHR policy/ planning documents.

Our framework creates six major criteria that are used to evaluate policy documents. These criteria are: 1) literature review, 2) source of primary information, 3) nature of recommendations, 4) implementation strategies, 5) credibility of authors and 6) credibility of publisher. Within each category, a score from zero to three (for criteria 1-4) or zero to two (criteria 5-6) is assigned, depending on the caliber of the document. Summing the scores from each section yields a document's overall score.

The intent of this measure is two-fold. Firstly, we want to create a tool that can be widely utilized by policymakers to help inform their decisions. Secondly, it can be used as a springboard to stimulate discussion and debate around HHR planning and policy formulation.

National Information Center on Health Services Research and Health Care Technology. (NICHSR) Health
Services Research and Health Policy Grey Literature Project: Summary Report. 2006. http://www.nlm.nih.gov/ nichsr/greylitreport_06.html. Accessed February 20, 2007.

\section{Disclosure of medical errors: A view through a global lens}

J. Kalra, H. Neufeld, A. Mulla. University of Saskatchewan, Royal University Hospital, Saskatoon, Sask.

There are ongoing efforts worldwide to minimize the occurrence of medical errors. However, the issue of honest disclosure of a medical error to the patient or their family has been relatively unattended. We have previously reported the Canadian provincial initiatives encouraging open disclosure of a critical event and have suggested its integration into a 'no-fault' model. In the absence of uniform policies directing appropriate disclosure of a medical error, substantial scope exists for breaching the patient's trust if errors during the process of care are not disclosed. We reviewed the various medical error disclosure initiatives across the globe to analyze the progress made in this key area. In 2001, the United States (US) Joint Commission on Accreditation of Healthcare Organizations (JCAHO) mandated an open disclosure of any critical event during care to the patient or their families. This was deemed as an essential accreditation standard for the institution. In Australia, the Australian Council for Safety and Quality in Health Care integrates the disclosure process with a risk management analysis towards investigating the critical event. In New Zealand, the patients suffering a medical error are rehabilitated and compensated through a no-fault, statefunded compensation scheme. The National Health Services (NHS) of the United Kingdom directs the doctors and managers to inform a patient of an act of negligence or omission that causes harm. The NHS scheme offers a remedial package to the patient including an apology and financial compensation in return for the patients waiving their right to litigate. The Canadian provincial initiatives, though similar in content, remain isolated because of their non-mandatory nature and absence of federal or provincial laws on 
disclosure. In Conclusion, we suggest that a uniform national policy centered on addressing errors in a nonpunitive manner and respecting the patient's right to an honest disclosure be implemented.

Kalra J, Massey KL, Mulla A. Disclosure of medical error: policies and practice. Journal of the Royal Society of Medicine 2005; 98(7): 307-09.

Hebert PC, Levin AV, Robertson G. Bioethics for clinicians: 23. Disclosure of medical error. CMAJ 2001; 164(4):509-13.

Mazor KM, Simon SR, Gurwitz JH. Communicating with patients about medical errors: a review of the literature. Arch Intern Med. 2004; 164(15):1690-7.

\section{The impact of government regulation of ambu- latory surgical facilities on access to elective surgi- cal procedures}

E. Fric-Shamji, M. Shamji. Duke University, Durham, NC, University of Ottawa, Ottawa, Ont.

Advances in medical technology have made freestanding ambulatory surgery centres a cost-effective method of delivering health care in the United States. One: Rapid expansion of such centres and duplication of services have raised concerns over rising health care costs, two: leading to government regulation of facilities via a Certificate of Need (CON) law in many states. Three: Such regulation may decrease access to elective procedures.

This study investigates access to elective surgical procedures in selected states with and without CON laws. Results of the Health Care Utilization Project were analyzed. Per capita rates of elective carpal tunnel release (CTR) and lumbar discectomy were evaluated in 16 states with CON laws and 5 states without CON laws over the years 2004-2005. Distribution of CTR and lumbar discectomy were analyzed by facility ownership and teaching status, using rates of emergent procedures as a control. Student's t-tests compared rates of CTR and discectomy as a function of CON legislation. Two-factor ANOVA extended this analysis to account for teaching environment and facility ownership.

Fewer CTR cases were performed in states with CON laws $(p=0.014)$, specifically in government- owned $(\mathrm{p}=0.012)$ and non-teaching facilities $(\mathrm{p}=0.01)$. No difference was observed in lumbar discectomy rates in states with respect to $\mathrm{CON}$ regulation. Distribution of both procedures among teaching and nonteaching centers was independent of CON laws. Facility ownership predicts fraction of these cases performed at an institution, $(\mathrm{p}<0.01)$ and this distribution is influenced by $\mathrm{CON}$ regulation, increasing fractions of both types of procedures performed at private, notfor-profit centers ( $\mathrm{p}=0.001, \mathrm{p}=0.003$ respectively).

We conclude that CON laws restrict access to certain procedures, specifically in government-owned and non-teaching facilities. These laws may limit the supply of surgical care, notably by redistributing away from government and for-profit centres. Potential solutions include reinvestigating the need for CON laws, or examining the $\mathrm{CON}$ methodology to accurately reflect need.

Small NC, Bert JM. Office Ambulatory Surgery Centers: Creation and Management. J Am Acad Orthop Surg 2003; 11:157-62.

Casalino LP, Devers KJ, Brewster LR. Focused Factories? Physician-Owned Specialty Facilities. Health Affairs 22(6):56-67.

Lanning JA, Morrisey MA, Ohsfeldt RL. "Endogenous hospital regulation and it's effects on hospital and nonhospital expenditures" Journal of Regulatory Economics1991 (June); 3(2):137-54.

\section{4. influences on choice of a generalist career in general surgery, general internal medicine and general pediatrics}

\section{Chung, L. Nickell, Generalism Task Force. University of Toronto, Toronto, Ont.}

We performed a literature review to summarize the primary influences that encourage or discourage the pursuit of careers in General Surgery (GS), General Internal Medicine (GIM), and General Pediatrics (GP). Relevant studies were identified through a PUBMED and MEDLINE search from 1982 to 2006. All included studies were peer-reviewed and pertained to factors influencing career choice in GS, GIM, GP, and their respective subspecialties. The identified literature was analyzed based on demography, the cur- 
riculum, and the nature of the discipline, etc. Consistent factors influencing career choice were established a priori as those supported by $\geq 2$ independent studies or reviews without contradictory findings reported to date. The top two factors favoring the choice of residency in GS are positive clerkship experiences and exposure to positive role models, whereas the top factors discouraging interest in GS are lifestyle issues and the length of residency. As for GIM, influences that favor the specialty include the female gender and preference for GIM upon entry into medical school. Factors that discourage the choice of GIM are high income expectations, the widening salary gap between generalist and specialist, negative clerkship experience and the type of patients in internal medicine. In pediatrics, the top two influences that favor GP are female gender and a predisposition for GP upon entry into medical school. A consistent factor that negatively influences career choice in GP is a favorable attitude towards research. To summarize, the main influences on the choice of a generalist career include gender, role modeling, clerkship experience, lifestyle issues, and financial compensation. Medical schools can encourage the pursuit of generalist careers by enhancing student exposure to positive role models and by providing a positive clerkship experience in GS, GIM, and GP.

Kirkham JC, Widmann WD, Leddy D, Goldstein MJ, Samstein B, El-Tamer M, Harari A, Arnell TD, John R, Hardy MA. Medical student entry into general surgery increases with early exposure to surgery and to surgeons. Current Surgery 2006 (Nov-Dec); 63(6):397-400.

Arora V, Wetterneck TB, Schnipper JL, Auerbach AD, Kaboli P, Wachter RM, Levinson W, Humphrey HJ, Meltzer D. Effect of the inpatient general medicine rotation on student pursuit of a generalist career. Journal of General Internal Medicine 2006 (May); 21(5):471-475.

Cochran A, Melby S, Neumayer LA. An internet-based survey of factors influencing medical student selection of a general surgery career. American Journal of Surgery 2005; 189:742-746.

\section{Meeting challenges in the delivery of surgical care}

L. Sigurdson. Dalhousie University, Halifax, NS.

Canadian surgeons are faced with looming demographic challenges. Shortages in surgical manpower cannot be addressed expediently due to 14-year university requirements. A potential solution is to increase the efficiency of surgeons already in practice. Physician assistants (PA's), may play a role in this regard by allowing surgeons to concentrate on their core competency, namely operating. The purposes of this investigation are to explore the inefficiencies in a current Canadian surgeon's practice, examine the feasibility of PA employment and evaluate the financial impacts.

The study was performed in 3 parts. In part 1, operating room plastic surgery Surgiserver ${ }^{\circledR}$ data for 10 years leading up to 2005 were analyzed to determine daily operating time actually used. In part 2, 4 months of detailed time series data were captured prospectively for every patient care event. The data was analyzed using SPSS (ver. 11.5) to determine the percentage and types of events that could be delegated to a PA. In part 3, PA hiring scenarios were developed using formal business case analyses.

Over 3,635 days, mean operating time used in a 10-hour surgical day was 5.93 hours. Of the 806 patients seen in 13 clinics, $53.5 \%$ could have been cared for by a PA. In the minor procedure area, $48.8 \%$ of surgical time was spent performing non-essential, PA compatible work. In the main OR, $25.9 \%$ of surgical time was PA compatible. Considering the weekly mix of activities, a PA could increase surgical productivity by $36.7 \%$. Hiring a PA was neutrally cost effective at the $37 \%$ productivity increase level. However, much greater discounted incremental cash flows, internal rates of return (IRR) and return on investments (ROI) were achieved when PA hiring allowed one surgeon to run 2 OR's simultaneously.

Employing PA's, in conjunction with increasing OR capacity, have the potential to markedly increase the capability of surgeons to deal with lengthy wait lists in a cost effective manner. 
McKibbin RC. Cost-effectiveness of physician assistants: A review of recent evidence. Pa J 1978; 8(2):110-115.

Maxfield RG. Use of physician's assistants in a general surgical practice. Am J Surg 1978; 131(4):504-508.

Kaissi A, Kralewski J, Dowd B. Financial and organizational factors affecting the employment of nurse practitioners and physician assistants in medical group practices. J Ambul Care Manage 2003; 26(3):209-216.

\section{Postgraduate training and its effect on practice location, career choice and practice profile: Track- ing 10 years of output from the University of Toronto}

C. Abrahams, S. Verma, R. Glazier, L. Jaakkimainen, S. Shultz. University of Toronto, Institute for Clinical Evaluative Sciences (ICES), Toronto, Ont.

The purpose of this study is to investigate the relationship between location and specialty of training and practice characteristics such as type of practice (i.e. community versus academic), socio-demographic profile of patients and their complexity, hospital/ health facility affiliations and workload/productivity.

The analysis required an extraction of registrant data from the University of Toronto Postgraduate Web Evaluation and Registration (POWER) system for a cohort of exiting residents and fellows from 1993 to 2003. The data extract was linked to several administrative databases held by ICES, including physician practice and billing information from the Ontario Health Insurance Plan (OHIP) and anonymized patient demographic data from the Registered Persons Database (RPDB).

Results of this study will inform workforce policy issues such as the overall contribution made by Toronto graduates to Ontario, other Canadian provinces and international practice pool of physicians, trends regarding medical career choice, similarities and differences between career choices of International Medical Graduates versus Canadian Medical Graduates, impact of location/program of training, impact of length of training and profile/ geography of patients served by graduates of Toronto. The study will aim to create a methodology/template for analysis that can be applied to other medical schools and catchment areas in human health resource planning.

Chan B, Willett J. Factors Influencing Participation in Obstetrics by Obstetrician-Gynecologists. 2004; 103(3):493-498.

Noble J, Baerlocher MO. Future Practice Profiles of Canadian Medical Trainees. Clinical and Investigative Medicine 2006; 29(4):288-289.

Watson DE, Katz A, Reid RJ, Bogdanovic B, Roos N. Family Physician Workloads and Access to Care in Winnipeg: 1991 to 2001. Canadian Family Physician 2004; 171(4):339-342.

\section{Boundaries or overlap: An examination of the comminity-oriented clinical practice of community medicine specialists and family general practitio- ners}

\author{
M.L. Russell, L. McIntyre. University of Calgary, Cal- \\ gary, Alta.
}

We compared the work settings and "communityoriented clinical practice" of Community Medicine (CM) specialists and family physicians/general practitioners (FP).

We conducted secondary data analysis of the 2004 National Physician Survey (NPS) to examine main work setting and clinical activity reported by $154 \mathrm{CM}$ (40\% of eligible CM in Canada) and 11,041 FP (36\% of eligible FP in Canada). Text data from the specialist questionnaire related to "most common conditions that you treat" were extracted from the Master database for CM specialists, and subjected to thematic analysis and coded.

CM specialists were more likely than FP to engage in "community medicine/public health" (59.7\% vs $15.3 \%)$; while the opposite was found for primary care (13\% vs. $78.2 \%)$. CM specialists were less likely to indicate a main work setting of private office/clinic/ community health centre/community hospital than were FP (13.6\% vs. $75.6 \%$ ). Forty-five percent of CM provided a response to "most common conditions treated" with the remainder either leaving the item blank or indicating that they did not treat individual patients. The most frequently named conditions in 
rank order were: psychiatric disorders; public health program/activity; respiratory problems; hypertension; and metabolic disorders (diabetes).

There is some overlap in the professional activities and work settings of CM specialists and FP. The "most commonly treated conditions" suggest that some CM specialists may be practicing primary care as part of the Royal College career path of "community-oriented clinical practice." However the "most commonly treated conditions" do not specifically indicate an orientation of that practice towards "an emphasis on health promotion and disease prevention" as also specified by the Royal College for that CM career path. This raises questions about the appropriateness of the current training requirements and career paths as delineated for CM specialists by the Royal College of Physicians \& Surgeons of Canada.

Bhopal R. Public health medicine and primary health care: convergent, divergent, or parallel paths? J Epidemiol Community Health 1995; 49:113-6.

Pettersen BJ, Johnsen R. More physicians in public health: less public health work? Scan J Public Health 2005; 33:91-8.

Stanwell-Smith R. Public health medicine in transition. J Royal Society of Medicine 2001; 94(7):319-21.

\section{The future of canadian residency education: The core competency project}

J. Frank, J. Nagle, R. Ramsarin, D. Danoff, P. Rainsberry. The Royal College of Physicians and Surgeons of Canada, Ottawa, Ont., The College of Family Physicians, Mississauga, Ont.

The Core Competency Project (CCP) is an initiative to reexamine fundamental recurring issues in Canadian medical education, including: (1) premature career decision making by medical students, (2) barriers to changing career disciplines by residents and practicing physicians, (3) lack of clarity on the role of "generalism" in medical training, and (4) the optimal structure and function of the PGME system. The CCP is a collaborative national endeavour of The Royal College of Physicians and Surgeons of Canada and the College of Family Physicians of Canada. From 2005 to 2007, the
CCP employed four primary methods, including: (1) a systematic review of relevant literature, (2) a series of commentary papers by leaders in medicine and medical education, (3) a series of focus groups across Canada involving medical students, residents, and practicing physicians, and (4) a national survey of stakeholders. This was supplemented by consultations with key groups in the medical profession. We describe the findings of these studies and the implications for medical education policy in Canada and around the world. The CCP is an unprecedented national medical education policy initiative.

\section{Prevalence of diagnostic discordance: A retro- spective analysis of autopsy findings and clinical diagnoses}

S. Suryavanshi, J.D.Gomez, A. Mulla, J. Kalra.

College of Medicine, University of Saskatchewan, Royal University Hospital, Saskatoon, Sask.

The prevalence of medical error in health care systems has compromised the quality of health care delivery. The research on medical errors in hospitalized population has consistently revealed high rates of misdiagnosis. Autopsy examination has been an established tool for quality assurance programs. The objective of this study was to determine the discrepancy rates between clinical and autopsy findings in patients admitted to various hospitals (Royal University hospital, RUH; St. Paul's hospital, SPH; Saskatoon city hospital, SCH) of Saskatoon Health Region. A retrospective record review of the medical and autopsy charts was carried out for all the deceased adult in-patients admitted during the years 2002, 2003, and 2004. All autopsies were carried out either in the morgue of RUH or at SPH hospital. A total of 3416 in-patient deaths were registered during the study period. Autopsies were performed on 206 of the deceased resulting in an autopsy rate of $6 \%$. In accordance with selection criteria, 158 cases were included for this study. The mean age of subjects was $66.6 \pm 15.2$ years with a range of $16-94$ years. The total concordance rate in this study between clinical and autopsy diagnoses was $75.3 \%$. The discordance rate was $20.9 \%$ and in $3.8 \%$ of the 
study population a conclusive clinical or autopsy diagnoses was not finalized. The concordance and discordance rate between clinical diagnoses and autopsy findings when compared between the patients of two hospitals (RUH and SPH) were not significantly different. These results suggest that despite the technical advances in medical and diagnostic modalities, there still persists a significant discordance in clinical and autopsy diagnoses. Our study confirms the wide prevalence of diagnostic discrepancies in the health care system and emphasizes the value of autopsy as an effective quality improvement and educational tool with a strong impact on quality management.

Roosen J, Frans E, Wilmer A, Knockaert DC, Bobbaers H. Comparison of premortem clinical diagnoses in critically ill patients and subsequent autopsy findings. Mayo Clin Proc 2000; 75:562-67.

Sonderegger-Iseli K, Burger S, Muntwyler J, Salomon F. Diagnostic errors in three medical eras: a necropsy study. Lancet 2000; 10355:2027-31.

Kalra J. Medical Error: An Introduction to Concepts. Clinical Biochemistry 2004;37:1043-51.

\section{Does Saskatchewan health policy encourage specialization?}

M.A. Megahed Gheis. University of Saskatchewan, Saskatoon, Sask., Regina Qu'Appelle Health Region, Regina, Sask.

This study targets the period between 2001 and 2006. Physician's pay statistics relating to all fee for service practitioners in Saskatchewan were collected. Data related to a number of independent variables commonly used in the design of pay policies were also obtained. These variables include physicians' places of training, availability of local graduates from each specialty program in Saskatchewan, physicians percentage turnover, changes of physician to population ratio in most specialties, average number of physician patient contacts in most specialties and income distribution skewness per specialty. Statistical analysis was carried out using STATA package version 9. Correlations between a number of variables was established. These correlations include Percentage turnover and change in pay per year between 2001 and 2006, Per- centage of provincial graduates to total work force per specialty on one hand and change in pay between 2001 and 2006 on the other hand. Change in pay on one hand and change in volume of clinical activities carried out on the other.

This paper revealed three relevant findings. Firstly Saskatchewan Health seems to have responded to the shortage of local graduates in certain specialties by allocating these specialties higher pay rise over the last five years. However this increase was associated with increased recruitment of foreign graduates. Secondly there was a consistent, mostly above inflation rate increase in pay for all specialists except clinical pathologists and diagnostic radiologists (two specialties with a relatively high local graduate retention rates). Thirdly, the overall increase in pay negatively correlated with the turnover rates in the case of family physicians, and did not adequately correlate with the changes in work load of the specialists. The writer argues that Saskatchewan Health has to adjust pay modification practices to respond more effectively to graduates recruitment and retention variables.

Blaufuss J, Maynard J, Schollars G. Methods of evaluating turnover costs. Nursing Management 1992 (May); 23(5):52-4,56,58-9.

Hyde JC, Fottler MD. Determinants of physician vacancy rates in rural hospitals. Journal of Rural Health 1994; 10(1):38-48, 1994.

Saskatchewan Health: Annual Financial Report 2006 and Annual Statistical Report 2006.

\section{Optimal care in rheumatoid arthritis: Prelimi- nary findings from a focus group study}
S. Bernatsky, D. Feldman, M. Roper, E. Rosenberg. McGill University, University of Montréal, Mon- tréal, Qué.

The objective of our work was to identify facilitators of optimal care, as well as potential barriers, for patients with rheumatoid arthritis (RA). The design was a focus group study. Individuals with established RA were identified through invitation letters sent using a random sample of the Quebec Arthritis Society mailing list. Patients were eligible for participation if they had a diagnosis of RA confirmed by a rheuma- 
tologist and if they had sought care within the McGill Réseau Universitaire Intégré de Santé network. We planned a series of focus group meetings (90 minutes each) to obtain sufficient data in terms of spectrum of ideas. In each moderator-led group, participants were asked to discuss five questions related to quality care. A co-moderator was available to document non-verbal communication, with audio-taping of all sessions and professional transcription for data analysis. Qualitative content analysis, based on grounded theory, was the chosen means of identifying recurring themes and categories.

Two focus group sessions have been completed with two more scheduled. Preliminary findings indicate the importance of good communication between family physicians, specialists, and allied health care workers. Final coding of transcripts and computerassisted content analysis is being completed. However it appears that focus group may be useful in studying optimal care for chronic diseases such as RA. Our preliminary findings emphasize the necessity of good communication among health care providers. Ultimately we hope to generate knowledge that can be transformed into better health for Canadians with arthritis and other chronic diseases.

\section{HISTORY OF MEDICINE - HISTOIRE DE LA MÉDICINE (22-44)}

\section{The warden and the doctor: Kingston peneten- tiary in the $1840 \mathrm{~s}$}

\section{R. Jacques. Queen's University, Kingston, Ont.}

Canada's first prison, Kingston penitentiary, opened its doors to six male inmates in 1835. This institution rested on a religious model, which postulated a dichotomy between good and evil people. Hence, suffering was justifiably inflicted to restore the convict to a state of grace.

This research will explore the life of prisoners and the awkward responsibilities of the physician, using as its principle sources the annual reports of the prison and the remarkable infirmary registry kept by Dr. James Sampson. While Warden Henry Smith pre- scribed the punishment, Dr. Sampson was obliged to verify that the inmate was fit to be punished. The physical and mental consequences of punishments were recorded in the prison's hospital registry.

The prison population tripled to approximately 500 from 1842-1845. Ten percent of the prison population was female, with the rest being adult male offenders, the criminally insane and boys, some as young as 8 years old. A single standard of punishment was impossible since it was permissible to hit children but not women. This paper will show the nature and frequency of punishments meted out by the Warden. It will demonstrate that there was a concomitant increase in the number of overall injuries. Morbidity was directly linked to punishment, but mortality was not.

Warden Smith was dismissed from office in 1848 on charges of starving the convicts and cruel, excessive punishment. Prior to his dismissal Dr. Sampson took a leave of absence as a statement of his inability to properly treat his patients and upon the warden's removal returned to his duties as the prison physician. Evidence from this study demonstrates that the prison physician was in a position of divided allegiance between his duty to the prisoner-patients and his duty to the moral code of his society as interpreted by the warden.

St. Onge D. Curator, Correctional Services Canada Museum. Kingston, Ontario, 2007.

Hennessy PH. Canada's Big House: The dark history of the Kingston Penitentiary. Toronto: Dundern Press, 1999.

Hospital Records, 1842-1848. The Archives of Queen's University at Kingston, Ontario.

\section{Coley's toxin \& spontaneous tumour regression}

\section{D.S. Hayre. University of Calgary, Calgary, Alta.}

William Coley, a young surgeon at New York Memorial Hospital, was traumatized by the loss of his first patient to bone cancer in 1891 . He was unable to save this young patient and she succumbed to her Sarcoma within 3 months of surgery. He searched the hospital archive to learn more about Sarcoma and discovered 
the case of a patient with a large sarcoma who had undergone five unsuccessful surgeries over a 3 year period. This case had been determined to be hopeless. After the last of these operations, the patient became very ill from an erysipelas infection.

Coley was astonished to read that after the fever broke and the patient had recovered, the tumour had vanished. Seven years later, the patient was still alive and well. Coley concluded that whatever had caused the fever must also have destroyed the cancer. Coley searched for and found this patient still in excellent health. Coley reasoned that if a chance infection could make tumours vanish, then a purposefully induced infection could do the same.

The hypothesis was tested by infecting his next 10 patients with Streptococcus pyogenes to cause Erysipelas. Some of the patients were difficult to infect, some died, and some had a strong reaction and their disease regressed. Coley switched to deactivated S. pyogenes to avoid the mortality observed with the live strain. Afterxperimentation with various formulations, a combination of $S$ pyogenes and Serratia marcescens was decided upon and became known as Coley's Toxin.

The preferred method of delivery was injection of the toxin directly into the primary tumour or metastases in increasing doses to avoid immune tolerance. Fever response in the patient was essential to imitate a naturally occurring infection and the body's natural response. Though Coley met with success, this therapy was abandoned as chemotherapy became more popular.

Hoption Cann SA, Gunn HD, van Netten JP, van Netten C. Dr William Coley and tumour regression: a place in history or in the future. Post Graduate Medical Journal 2003; 79:672-680.

Hobohm U. Fever and Cancer in Perspective. Cancer Immunology \& Immunotherapy 2001; 50:391-396.

Grange JM, Standord JL, Stanford CA. Campbell De Morgan's 'Observations on cancer', and their relevance today. Journal of the Royal Society of Medicine 2002 (June); 95:296-299.

\section{The controversial conquering of pain.}

D. van Heerden. University of Calgary, Calgary, Alta.

Before the extensive use of anaesthesia, great surgeons were measured by how little pain could be caused to patients in the shortest possible time. Simple operations, such as the extraction of rotting teeth, were terrible nightmares to patients. Some people compared surgery to the Spanish inquisition and there are many accounts in the literature of yells, screams, panicking, and resistance in the operating room. Because of this, before anaesthesia, surgery was mainly restricted to amputations and external growth removals and little advancements could be made over hundreds of years.

Five men make the claim to have conquered the horror of surgery in the operating room by discovering ether as an anaesthetic agent: William T.G. Morton, Charles T. Jackson, Crawford W. Long, Horace Wells, and William Clarke. However, only William T.G. Morton is credited with discovering ether as an anaesthetic agent. Mr. Morton publicly used ether during the excision of a tumour from a patient's neck on October 16, 1846 at the Massachusetts General Hospital in Boston.

But William T.G. Morton was not the saint that he portrayed himself to be. There is no doubt that he made the first public discovery of anaesthesia but there is doubt as to whether it was because of his great knowledge and research in the field, or because he took advantage of an opportunity to display this borrowed method to the public.

Keys TE. The History of Surgical Anaesthesia. New York: Dover Publications, 1963.

Smith HM, Bacon DR. The History of Anesthesia. Clinical Anaesthesia. (PG Barash, B. Cullen, RK Stoeling, eds.) Philadelphia: Lippincott, Williams and Wilkins, 2006.

Wolffe RJ. Tarnished Idol. California: Norman Publishing Company, 2001. 


\section{A Christmas conundrum: What ailed Tiny Tim?}

\section{Bogle. University of Calgary, Calgary, Alta.}

Tiny Tim Cratchit is the captivating soul of one of the English language's most beloved stories, Charles Dickens' A Christmas Carol. His mysterious crippling disorder is quite the medical enigma, being intermittent, unilateral and fatal if left untreated. His tiny stature can also be counted amongst his symptoms. However, the most startling aspect of his condition is its ability to be cured in 1840s London with Ebenezer Scrooge's limitless funds.

While Tim is saved after Scrooge's reformation, Dickens never mentions what disease afflicted the little youngster. Upon examining Dickens personal health and previous literary talent of describing diseases unknown to medical science at the time, the ailment is validated as an accurate depiction of a real malady.

Two major theories exist as to the nature of the disease. Tuberculosis and renal tubular acidosis are offered as explanations to the interesting symptoms Tim experienced. The debate hinges on the interpretation of the original manuscript that, 'Tiny Tim did not die.' While survival is possible from the more common tuberculosis in 1843, a full cure was available from renal tubular acidosis via the alkali tonics available at that time. The debate may rage on indefinitely.

Callahan C. Tiny Tim remembered. Am J Dis Child 1991; 145:1355-6.

Jones P. Dickens' literary children. Aust Pediatr J 1972; 8:233-45.

Lewis D. What was wrong with Tiny Tim? Am J Dis Child 1992; 146:1403-1407.

\section{Nothing but the truth, so help me God: The his- tory of magnetic resonance imaging}

\section{A. Dechant. University of Calgary, Calgary, Alta.}

On the morning of October 10, 2003, the residents of New York awoke to find that an entire page of their beloved paper, The Times, had been usurped for the sole purpose of flagrant self-promotion and protesta- tion. On his own behalf, Dr. Raymand Damadian had purchased a one page spread bemoaning his exclusion in the Nobel Prize for Medicine that year which had previously been awarded to Paul Laterbur and Peter Mansfield for their contributions to the development of Magnetic Resonance Imaging (MRI). Over the course of the next few months, the public was to witness a series of such articles proclaiming that a shameful wrong had been committed, and that the truth would eventually prove Dr. Damadian's accusations.

That truth lay in the early theoretical and technical foundations that led to the discovery of MRI. Described just after the Second World War, nuclear magnetic resonance (NMR) was hailed as a breakthrough in physical chemistry for which Felix Bloch and Edward Purcell were awarded the Nobel Prize in Physics in 1952. Two decades later, in 1971, Dr. Damadian discovered that differences between the NMR signals of cancerous and normal tissue might provide a rapid means of cancer detection. However, Laterbur and Mansfield were the first to actually demonstrate images of live tissue using the application of magnetic gradients - the key to modern MRI.

Though speculation exists that Dr. Damadian may have been excluded from the prize due to his religious beliefs or political rivalry, only time will reveal the whole truth when the Nobel files are opened 50 years hence.

Bradley W. The Nobel Prize: Three Investigators Allowed but Two Were Chosen. Journal of Magnetic Resonance Imaging 2004; 19:520.

Laterbur P. Image formation by induced local interactions: examples of employing nuclear magnetic resonance. Nature 1973; 242:190-191.

Mansfield P, Grannell P. "NMR diffraction in solids?" Journal of Physics C: Solid State Physics 1973; 63:L433-L426.

\section{Immigration and other evils: A profile of Dr. C. K. Clarke and the eugenics movement in Canada}

L. Lee. Queen's University, Kingston, Ont.

Dr. C.K. Clarke (1857-1924) was one of Canada's most prominent psychiatrists. He sought to improve 
the conditions of asylums, helped to legitimize psychiatry and established formal training for nurses.

At the beginning of the $20^{\text {th }}$ Century, Canada experienced a surge of immigration. Yet - as many historians have shown - a widespread anti-foreigner sentiment within the public remained. Along with many other members of the fledgling eugenics movement, Clarke believed that the proportion of "mental defectives" was higher in the immigrant population than in the Canadian population and campaigned to restrict immigration. He appealed to the government to track immigrants and deport them once they showed signs of mental illness. Clarke's efforts lead to amendments to the Immigration Act in 1919, which authorized deportation of people who were not Canadian-born, regardless of how many years that had been in Canada. This change applied not only to the mentally ill but also to those who could no longer work due to injury and to those who did not follow social norms.

Clarke is a fascinating example of how we judge historical figures. He lived in a time where what we now think of as xenophobia was a socially acceptable, even worthy attitude. As a leader in eugenics, therefore, he was a progressive. Other biographers have recognized Clarke's racist opinions, some of whom justify them as keeping with the social values of his era. In further exploring Clarke's interest in these issues, this paper relies on his personal scrapbooks held in the CAMH archives. These documents contain personal papers, poems and stories that proclaim his antiSemitic and anti-foreigner views. Whether we allow his involvement in the eugenics movement to overshadow his accomplishments or ignore his racist leanings to celebrate his memory is the subject of ongoing debate.

Dowbiggin IR. Keeping America Sane: Psychiatry and Eugenics in the United States and Canada 1880-1940. Ithaca and London: Cornell University Press, 1997.

McLaren A. Our Own Master Race: Eugenics in Canada 1885-1945. Toronto: McClelland and Stewart, 1990.

Roberts B. Whence They Came: Deportation from Canada 1900-1935. Ottawa: University of Ottawa Press, 1988.

\section{Lothotomy through the ages: Big stones, small stones and all the ways to cut them out}

\section{J.E. Elliott. University of Manitoba, Winnipeg, Man.}

The first known specimen of urological interest was a vesicle calculi dated to $5000 \mathrm{BC}$, found by Elliot Smith in 1901, in an ancient tomb in Egypt. Since these ancient times, urolithiasis has been a condition which fascinated and frustrated the medical world, both in understanding of its etiology and in how to treat patients afflicted with such stones.

Medical management of urinary calculi has a complex and suspect past; when such therapies failed, as their mystical and unscientific approaches often did, patients sometimes resorted to more drastic and dramatic means such as lithotomy.

Lithotomy was known since early times in India and Persia; when it was introduced to Europe is unclear. Writings by Susruta in India describe early forms of the procedure, and techniques were improved by Celsus of Rome ( $1^{\text {st }}$ Century AD), remaining in use, largely unchanged until the eighteenth Century.

Marianus Sanctus (1490-1550) described a technique, the "grand appareil" which superseded the Celsus method, and other approaches by Franco (1500-1570), Jacques de Beaulieu (1651-1714), Johann Rau (1658-1709) and William Cheselden (16881752) gained and lost dominance over the centuries.

Perhaps most interesting about lithotomy was the development of the tools used in its practice. From the beginning, the various knives, forceps, dilators and sounds became ever more complicated, intricate and gruesome looking, resembling more the armamentarium of a torture master than the curative tools of a physician.

As endoscopic techniques began and evolved, the necessity to make large incisions for stone removal decreased. Nonetheless, the approaches and instrumentation used to treat bladder stones helped shape the practice of urology and contributed to the continuing goal of minimizing invasion of the patient while still providing effective treatment of stone disease and other genitourinary problems. 
Murphy LJT. The History of Urology. Springfield, Ill.: Charles C. Thomas, 1972.

Chevalier RL. Kidney and urologic disorders in the age of enlightenment. Am J Nephrol 1994; 14(4-6):461-6.

Herman, JR. Urology; a view through the retrospectroscope. Hagerstown, Md.: Harper \& Row, 1973.

\section{The changing concept of aging and the quest for immortality}

D. Wile, University of Calgary, Calgary, Alta.

The desire to extend human lifespan has spurred scientific and philosophical interest back to the earliest recorded piece of human literature, the Epic of Gilgamesh, which documents the quest of a mythical king to become immortal. In the intervening years between then and now, and particularly in the last century, human lifespan has increased dramatically. Though it is commonly held that there is an upper biological limit to human lifespan, there are some who believe its recent meteoric rise can continue indefinitely.

The story of human lifespan has two largely separate prongs: that of the important advances in sanitation, agriculture and medicine that have effected the greatest change in our life expectancy, and the recurring myth, legend and popular beliefs surrounding greatly advanced or eternal human life.

In recent years, the myth and science of life expectancy have coalesced, creating a core group of people who believe that immortality is a technically achievable goal. Such claims have muddied the concept of aging such that it is now commonly described as both a disease process and a fundamental part of life.

Hackler C. Extending the life span: Mythic desires and modern dangers. HEC Forum, 2006; 16:182-196.

Holliday R. Aging is no longer an unsolved problem in biology. Ann. N.Y. Acad. Sci. 2006; 1067:1-9.

Rando TA. Stem cells, ageing and the quest for immortality. Nature 2006; 441:1080-1086.

\section{Abortion and the fall of midwifery in $19^{\text {th }}$ cen- tury North America}

\author{
C. Schram. Queen's University, Kingston, Ont.
}

The $19^{\text {th }}$ Century in North America was a time of many social and scientific changes that impacted the field of medicine. A result of one such change was the medicalization of childbirth, as the primary care of women during labour shifted from midwives to physicians. While there is ample discourse on the many factors that contributed to this shift, there is very little discussion on the role played by abortion. Studying abortion in the $19^{\text {th }}$ Century is often limited by a paucity of primary sources from the physicians who performed abortions and women who obtained them. Although most authors who discuss the midwifery shift do not make any mention of a role played by the issue of abortion, it has been addressed and supported by primary sources. This raises the question, why is abortion not discussed in histories on the medicalization of childbirth by other authors?

The objectives of this paper are historical and histographic. First, it will present the evidence on the use of abortion as a political tool employed by some policy makers, physicians and the media to discourage women from choosing midwives for their childbirth care. Second, it will analyze possible reasons why this topic is not addressed by the majority of historians of childbirth in $19^{\text {th }}$ Century North America. Are the authors concerned about the varying social views of abortion, the associated politics, the lack of primary sources, or are they personally uncomfortable with the subject? Only the authors themselves can truly know their reasons for neglecting the subject of abortion in their work, but this analysis will show how issues that influence historians determine the version of the past that is produced and propagated into the present and the future.

Borst CG. Catching Babies: the Professionalization of Childbirth, 1870-1920. Cambridge, Mass.: Harvard University Press, 1995.

Bourgeault B, Davis-Floyd R, eds. Reconceiving Midwifery. Montreal \& Kingston: McGill-Queen's University Press, 2004. 
Dodd DE, Gorham D, eds. Caring and Curing: Historical Perspectives on Women and Healing in Canada. Ottawa: University of Ottawa Press, 1994.

Wertz DC, Wertz RW. Lying In; a History of Childbirth in America (expanded edition published 1989 by Richard W. Wertz and Dorothy C. Wertz) New York: Free Press; London: Macmillan, 1977.

Reagan LJ. Linking midwives and abortion in the Progressive Era. Bulletin of the History of Medicine 1995; 69(4):569-98.

Reagan LJ. When Abortion Was a Crime, Women, Medicine, and Law in the United States, 1867-1973. London: University of California Press, 1997.

\section{The birth of a new specialty: The history of emergency medicine in Canada}

R. Elyas. Queen's University, Kingston, Ont.

Modern day emergency rooms across Canada have almost completely transformed over the past 30 years; perhaps more so than any other specialty. Before the 1970 's, it was primarily general practitioners working on a part-time basis who ran our emergency departments. Some hospitals used interns and residents as first-line emergency care providers, often under the direction of a surgeon or internist. Emergency Medicine has evolved into a highly sophisticated and respected medical specialty that extends beyond clinical medicine, into both research and academia. The appeal of Emergency Medicine is so great that it is now one of the most sought after specialties in the annual CaRMS match. The success story of Emergency Medicine is characterized by the tireless efforts and determination of its founders across the country. They fought for adequate and supervised care of the acutely ill or traumatized patient, believing in a special body of knowledge that should be available to physicians who spend most, if not all, their time in Emergency Departments. In 1977, these founders formally united and The Canadian Association of Emergency Physicians was born. A few years later, in 1980, Emergency Medicine was finally designated as a free-standing specialty by the Royal College of Physicians and Surgeons of Canada. Meanwhile, the College of Family Physicians of Canada also sought to establish a paral- lel route for Emergency Training of Family Physicians, feeling that Emergency Medicine lay within the realm of Family Medicine. The result was that both colleges established Emergency Medicine training programs that exist until this day.

Using journals, archives, a survey, and interviews, the paper will trace the history of the professionalization of Emergency Medicine in Canada.

Johnson R. The Canadian Association of Emergency Physicians. The Journal of Emergency Medicine 1993; 11:362-364.

Reudy J, Seaton T, Walker D, Rowat B, Cassie J. Report of the Task Force on Emergency Medicine: RCPSC Accreditation Section, 1988.

Walker DMC. History and Development of the Royal College Specialty of Emergency Medicine. Annals Royal College of Physicians and Surgeons of Canada 1987; 20:349-352.

\section{Relearning in military surgery: The contribu- tions of Princess Vera Gedroits}

B. Wilson. University of Calgary, Calgary, Alta.

It is a well known truth that knowledge is often forgotten and has to be relearned. In medicine, this unfortunate trend is especially prevalent in the history of military surgery. The story of a Russian Princess, military surgeon, and poet, Dr. Vera Gedroits is one such forgotten story. Dr. Gedroits' largely unrecognized contribution to military surgery was the adoption of laparotomy for penetrating abdominal wounds (PAWs).

In the latter half of the $19^{\text {th }}$ Century, the treatment of PAWs was controversial. However, the results of the Spanish-American (1898) and Boer (1899-1902) Wars and the outspoken opinions of prominent experts unified medical opinion; conservative treatment was clearly established as the treatment paradigm for PAWs at the birth of the $20^{\text {th }}$ Century. Indeed, conservative treatment was officially adopted by the Russians at the outset of the Russo-Japanese War (19041905).

During this war, the bold surgical practices of Dr. Gedroits would seriously challenge this standard of care. Dr. Gedroits performed operations in a converted 
railway car in a Red Cross hospital train. Despite these suboptimal conditions, she performed laparotomies on victims of PAWs with unprecedented success. These results, which were largely due to strict surgical indications and technical skill, effectively demonstrated the importance of laparotomy in the treatment of such wounds. As a result, the Russians adopted operative treatment as the new standard of care. Interestingly however, no other countries seemed to take any notice. Dr. Gedroits' results were barely remarked upon and quickly forgotten. Indeed, contemporary Western observers of the Russian medical outfit, and historians since, have interpreted the surgical results of the war to support conservative management. It was not until WWI, ten years later, that surgeons relearned the utility of laparotomy. The story of Dr. Gedroits, both before and after her innovative treatment in the Russo-Japanese war, deserves remembering.

Bennett J. Princess Vera Gedroits: military surgeon, poet, and author. British Medical Journal 1992; 305(6868):1532-1534.

Harvard V, Hoff J. Reports of Military Observers Attached to the Armies in Manchuria during the RussoJapanese War. London: HMSO, 1908.

Wallace C. War surgery of the abdomen. Lancet 1917 ; 189(4885):561-5568.

\section{3. how to steal a body}

\section{Turner. University of Calgary, Calgary, Alta.}

You are a medical student in 1820 , training in anatomy has now become a prerequisite to graduation but there are limited cadavers available for dissection. Could you be a body snatcher? What about if you only took unclaimed bodies? What if you didn't actually excavate, just helped drive the wagon? What would be your conditions before you would turn to a life of crime? Keep in mind that just by "borrowing" the occasional body you would provide yourself with ample opportunities to learn anatomy and also easily afford your tuition.

If you do decide to go ahead and become a body snatcher you're going to have to learn the classic modus operandi employed by the best in the business.
First of all you want to do some daytime reconnaissance by attending the burial to see if any booby traps are being set for potential body snatchers. Next, you return at night with a wagon and drop two men off at the burial site. They then start digging a 3'X3' hole until they hit the coffin. The body is carefully extracted and any identifying clothing or jewelry is removed and put back in the coffin before being reburied.

Now you might be worried about retribution but you really don't have much to fear. Townsfolk have been known to protest in front of medical schools but you'd have to deal with this even if you weren't a body snatcher. If you end up going to court the worst that would happen is a fine that you could easily pay off by stealing another body or two.

Highet MJ. 2005. Body snatching and grave robbing: bodies for science. History and Anthropology 2005; 16(4):415-440.

MacGillivray R. Body snatching in Ontario. CBMH/ BCHM 1988; 5:51-60.

Ross I, Ross CU. Body snatching in 19th Century Britain: from exhumation to murder. British Journal of Law and Society 1979; 6(1):108-118.

\section{A bried history of cardiac arrythmia}

\section{$R$. Ducas. University of Manitoba, Winnipeg, Man.}

Throughout the ages there has been little else as impressive to both the patient and physician as abnormalities and aberrancy in the heartbeat. It was through careful observation and characterization of physiology that the tactile measurement of the pulse translated and evolved in to the vast field of cardiology we know today. For thousands of years the only window physicians had into the hearts of their patients was through palpation of a pulse. The ancient Egyptians, Chinese and Greeks are credited with measurement and characterization of peripheral pulses and their association with illness. The work of Claudius Galen (129-199) furthered the association of pulse to cardiac function. Galen's work set the stage for William Harvey's (1578-1657) first description of the circulatory system and thereafter the function of the heart. However, it was not until the advent of electrocardiography that 
modern, efficient studies of cardiac rhythm began. The work of August Desir Waller (1856-1922) and Willem Einthoven (1860-1927) revolutionized the study of arrhythmia with the advent of the electrocardiogram (ECG). This instrument transformed the diagnosis of heart disease and catalyzed the creation of cardiology as a subspecialty. It was through the use of the ECG that cardiac rhythm disorders were first characterized. James Mackenzie and Arthur Cushny first recognized atrial fibrillation and the work of Drs. Wolf, Parkinson and White theorized the neuro-cardiac function of the heart. Further study led to the discovery of the Purkinje system and the mechanics of cardiac electrical conduction. Medicine has thus used many approaches in the treatment of arrhythmias, employing pharmacology, electricity and surgery, with an ever-evolving spectrum of treatment. It was through observation, innovation and determination that diseases of the heart are understood and treated today.

Hanon S, Shapiro M, Schweitzer P. A troubled beginning: Evolving concepts of an old arrhythmia. J. Electrocardiol. 2005 (July); 38(3):213-7.

Fye,W. Tracing atrial fibrillation - 100 years. N Engl J Med. 2006 (Oct); 5;355(14):1412-4.

Lüderitz B. History of the disorders of cardiac rhythm. $3^{\text {rd }}$ Ed. Armonk, NY: Futura Pub. Co., 2002.

\section{Models that change: The study of gay identity development}

K. Heng. University of Calgary, Calgary, Alta.

Since the declassification of homosexuality as a mental disorder by the American Psychiatric Association in 1974, a large number of models of gay identity development have been proposed in the literature. This is unique because for the first time, more attention was paid to the process of developing a gay identity rather than theorizing about the etiologies of homosexuality. This paper reviews the changes in thought found in the literature describing how one comes to develop a gay identity.

For the marginalized, identity development is generally described against a backdrop of stigma. Fortunately, our current society is very different from the hostile world that surrounded the APA in 1974: homo- sexuality is more tolerated and accepted, laws are less discriminatory, and gay role models are more abundant and accessible. As society has evolved, so too have its descriptive models. Shame and reluctance are found in Plumer's (1975) and Lee's (1977) models. Pride and activism appear in Hencken and O'Dowd's (1977) and Cass' (1979) models. Troiden (1989) mentions the fear of AIDS in his writings. Alderson's (1998) model reflects a climate where religion, friends, and society can be catalysts in developing a positive identity. Taken together, these models are like time capsules containing clues as to the social conditions of the time.

As the rate of social evolution accelerates, it is doubtful that any model regarding marginalized individuals will ever become definitive. For the case of homosexuality, if and when its stigma is removed, then the defining feature of gay identity development is also removed. It is possible that in its place will be a general model of sexual identity development, where homosexual and heterosexual paths diverge innocently and quietly in a society that does not value one over the other.

Alderson K. The ecological model of gay male identity. The Canadian Journal of Human Sexuality 2003; 12(2):75-85.

Cass V. Homosexual identity formation: A theoretical model. Journal of Homosexuality 1979; 4(3):219-35.

Troiden R. The formation of homosexual identities. Journal of Homosexuality 1989; 17(1/2):43-73.

\section{Practicing medicine and music II: Ophthalmol- ogy and music}

\section{L.P. Hwi, J.W. Ting. Faculty of Medicine, University of Manitoba, Winnipeg, Man.}

Cecil Cameron Ewing (1925-2006) was a lecturer and head of ophthalmology at the University of Saskatchewan. Throughout his Canadian career, he was an active researcher who published several articles on retinoschisis and was the editor of the Canadian Journal of Ophthalmology. For his contributions to Canadian ophthalmology, the Canadian Ophthalmological Society awarded Ewing a silver medal. Throughout his celebrated medical career, Ewing maintained his 
passion for music. His love for music led him to be an active member in choir, orchestra, opera and chamber music in which he sang and played the piano, violin and viola. He was also the director of the American Liszt Society and a member for over 40 years.

The connection between music and ophthalmology exists as early as the $18^{\text {th }}$ Century. John Taylor (1703-1772) was an English surgeon who specialized in eye diseases. On the one hand, Taylor was a scientist who contributed to ophthalmology by publishing books on ocular physiology and diseases, and by advancing theories of strabismus. On the other hand, Taylor was a charlatan who traveled throughout Europe and blinded many patients with his surgeries. Taylor's connection to music was through his surgeries on two of the most famous Baroque composers: Johann Sebastian Bach (1685-1750) and George Frederick Handel (1685-1759). Bach had a painful eye disorder and after two surgeries by Taylor, Bach was blind. Handel had poor or absent vision prior to Taylor's surgery, and his vision did not improve after surgery. The connection between ophthalmology and music spans over three centuries from the surgeries of Taylor to the musical passion of Ewing.

Ewing E. Cecil Cameron Ewing. BMJ 2006; 332(7552):1278.

Jackson DM. Bach, Handel, and the Chevalier Taylor. Med Hist 1968; 12(4):385-93.

Zegers RH. The Eyes of Johann Sebastian Bach. Arch Ophthalmol 2005; 123(10):1427-30.

\section{Unlikely bedmates: A critical look at the history of public health and prostitution}

S. Berkhout. Faculty of Medicine, the Department of Philosophy, University of British Columbia, BC Centre For Excellence in HIV/AIDS, Vancouver, BC.

The trope of the prostitute as a vector of sexually transmitted disease is longstanding, though not as old as the profession itself. The regulation and control of sex work also boasts of an incredibly long history; the practices that have developed into the field of public health in particular have been an important source of the ideology suffusing sex work, as well as the social identities associated with sex workers.

A general form of a 'medical police' (to borrow from Foucault) emerged rather abruptly in the $18^{\text {th }}$ Century, gaining greater support with the advent of positivism in the early $19^{\text {th }}$ Century. The developing methods of epidemiology were intertwined with the uncovering of correlations between poverty, class, and disease, providing both a methodological and ethical foundation for public health interventions and social control, including the legal regulation and sequestering of women thought to be prostituting, forced medical examinations, as well as moral rehabilitation campaigns directed toward sex workers. The breadth of interventions justified by the interests of public health demonstrates that the relationship between public health and prostitution is far deeper than the use of population statistics and outbreak investigations to curb the spread of disease.

In this paper, I consider some of the various ways in which prostitution has been constructed through norms regarding class, gender, and sexuality, and how aspects of the historical relationship between public health practices and prostitution have influenced, and been influenced by, these understandings. Appreciating the historical context of sex work and public health is of significance, given that current ideas about appropriate interventions and regulations continue to be informed by this type of politics of health.

Bell S. Reading, Writing, and Rewriting the Prostitute Body. Indiana University Press, 1994.

Brock D. Making Work, Making Trouble: Prostitution as a Social Problem. Toronto: University of Toronto Press, 1998.

Lupton D. The Imperative of Health: Public Health and the Regulated Body. Sage Publications, 1995.

\section{Max Brodel (1870-1941): His artistic influence on surgical learning at John Hopkins Medical School}
P. Pace-Asciak, T. Gelfand. The University of Ottawa, Ottawa, Ont.

Medical students depend on illustration to learn anatomical facts and details that may be too subtle for the 
written or spoken word. For surgical disciplines, learners rely on tools such as language, 2-dimensional illustrations, and 3-dimensional models to pass on important concepts. Although a photograph can convey factual information, illustration can highlight and educate the pertinent details for understanding surgical procedures, neurovascular structures, and the pathological disease processes.

In order to understand the current role of medical illustration in education, one needs to look to the past to see how art has helped solve communication dilemmas when learning medicine. This paper focuses on Max Brodel (1870-1941), a German-trained artist who eventually immigrated to the United States to pursue his career as a medical illustrator. Shortly after his arrival in Baltimore, Brodel made significant contributions to medical illustration in Gynecology at John Hopkins University, and eventually in other fields of medicine such as Urology and Otolaryngology. Brodel is recognized as one of America's most distinguished medical illustrators for creating innovative artistic techniques and founding the profession of medical illustration.

Today, animated computer based art is synergistically used with medical illustration to educate students about anatomy. Some of the changes that have occurred with the advancement of computer technology will be highlighted and compared to a century ago, when illustrations were used for teaching anatomy due to the scarcity of cadavers.

Schultheiss D, Udo J. Max Brodel (1870-1941) and Howard A.Kelly (1858-1943) - Urogynecology and the birth of modern medical illustration. European Journal of Obstetrics \& gynecology and Reproductive Biology 1999; 86:113-115.

Crosby C. Max Brodel: the man who put art into medicine. New York: Springer-Verlag, 1991.

Papel ID. Max Brodel's contributions to otolaryngology - Head and Neck surgery. The American Journal of Otology 1986; 7(6):460-469.

\section{Thomas hodgkin. 1978-1866. Health advocate for Manitoba}

P. Warren. University of Manitoba, Winnipeg, Man.

CanMEDS 2005 includes health advocate. Pertinently Michel Foucault wrote "The first task of the doctor is therefore political...Man will be totally and definitively cured only if first liberated." No one exemplified this more than Thomas Hodgkin widely known for his eponymous disease. What is less known is his unceasing work, as a Quaker, for aboriginal people around the world. He was secretary of the Aboriginal Protection Society. He had been interested in Canada since meeting John Norton, as a teenager. His involvement in the plight of Canada's Indians may have cost him a staff position at Guy's Hospital; the Treasurer, Benjamin Harrison, is quoted as saying "he would have no officer of the hospital who drove about with a North American Indian in his carriage." Hodgkin played an active role in the history of Manitoba. His friend Dr Richard King undertook expeditions in Western Canada to find Sir John Franklin corresponded with Hodgkin on his anthropological observations on the Aboriginals and the treatment of them by the Hudson's Bay Company (HBC). Hodgkin campaigned actively about the management of the Manitoba aboriginals by the HBC. The presentation will illustrate this with excerpts from his letters to Sir George Simpson, Governor HBC, from Captain Kennedy who also sought Franklin and the archives of the Faculty of Medicine, University of Manitoba. He presented evidence to the House of Commons as HBC was ceded to Canada. As editor of the Colonial Intelligencer he wrote much on Manitoba and received a letter from Louis Riel. Hodgkin was passionately committed to ensure that people were free both politically and economically.

Foucault M. The Birth of the Clinic. Archaeology of Medical Perception. trans. A.M. Sheridan Smith. New York: Vintage Books, 1994.

Wilks S, Bettany GT. A Biographical History of Guy's Hospital. London: Ward, Lock and Co., 1892.

Kass AM, Kass EH. Perfecting the World. The Life and Times of Dr. Thomas Hodgkin 1798-1866. Boston: Harcourt Brace Johanovich Publishers, 1988. 


\section{The evolution of prosthetics}

A. Kam. Faculty of Medicine, University of Manitoba, Winnipeg, Man.

Throughout history, prosthetic limbs have undergone significant changes in design and function. For example, an ancient bronze and iron prosthesis with a wooden core, discovered in Italy and dated back to $300 \mathrm{BC}$, has evolved into a modern shock-absorbing multi-axis prosthetic foot for walking on uneven ground. Recent advances in "neuro-controlled" prosthetics with microprocessor controllers further allow their users to produce smooth, multi-joint movements, simulating "real limbs". With an increase in government funding focusing on researches in independent mobility, it is expected that new designs will improve immensely the quality of life of amputees. Are we approaching closer to the "ideal prosthetic limb"? The objective of this paper is to examine the evolution of various prosthetic designs and to re-apply some of the old concepts into new designs. The method used is mainly literature review. Results/conclusion: N/A.

Wetz H, Gisbertz D. History of artificial limbs for the leg. Orthopade 2000; 29(12):1018-32.

Pascual G. Amputations, walking and prosthesis development. An R Acad Nac Med (Madr) 2003; 120(3):593-607.

Cottrell-Ikerd V, Ikerd F, Jenkins DW. The Syme's amputation: a correlation of surgical technique and prosthetic management with an historical perspective 1994; 33(4):355-64.

\section{The cost of mistakes: Penalties for surgical malpractice through the ages}

\section{B.A. Vartian. University of Calgary, Calgary, Alta.}

In recent years the United States has undergone what some have termed a malpractice "crisis". It has affected Canada and other parts of the world to a lesser extent and has been the subject of much debate. Throughout history the idea of what constitutes negligent surgical care and its consequences has not been an immutable concept but rather has fluctuated between seemingly polar extremes.
In ancient Mesopotamia, the Hammurabi code describes bountiful rewards for successful surgery contrasted with mutilation or death for failed attempts. In ancient Egypt we see the extremes of strict dogma, where acceptable practice was laid out by ancient priestly documents and those who strayed from their precise format could be met with deportation or beheading, a practice that discouraged developing treatment for those with a poor chance of survival. In stark contrast to these cultures the physician/surgeons of ancient Greece had almost complete impunity. After the monastic orders in Europe were banned from surgical practice in 1130 the uneducated barber surgeons dominated the field. The minority of educated surgeons pointed out many examples of negligence and improper care by this group. Capital punishment and mutilation of negligent surgeons became common once again in the crusader states, as public humiliation was added to the punishment. During the renaissance in Italy, the actions of a regulatory council levied stiff fines for surgeons who infringed on the practice of physicians while seemingly paying very little attention to examples of gross negligence and patient abuse. Finally in the modern era, surgery developed much more effective treatments for many conditions. Paradoxically as soon as a technique became better for a condition, accusations of negligence for treatment of that condition became common.

\section{The psychoneuroimmunophysiological re- sponses to incongruous actions or statements/ prevarications made for the purpose of eliciting rhythmic, spasmodic expiratory reflexes}

\section{S. Ahmed. University of Calgary, Calgary, Alta.}

Although humans know instinctually that humour has healing powers, an understanding of the precise effects of humour and laughter had been largely unknown until the twentieth Century, due to the lack of technology. Not all of the barriers to research have been removed - it is still not possible to know "how much" good humour a person has or is experiencing but there have been significant discoveries that help to 
prove that while laughter may not be the best medicine, it certainly helps the medicine go down.

The understanding of humour has come in four distinct areas, and in periods that reflect the available technologies. With the discovery of laughing diseases, interest in humour drove Harry Paskind in 1932 to create a new machine to study muscle tone during good humour. From the 1950s to 1970s, the neurology of laughter was researched, accompanying further research into the pathology of laughter after an epidemic of laughter in Uganda from 1962-64. After this came the study of the immunology and the discovery that laughter fights cancer, with the champion of laughter research, William Fry, dedicating a decade from 196979 to this work. Finally came research on the indisputable effect of laughter - its healthy effects on human psychology. Thanks, in part, to this research, and also supporting it, the past forty years have seen men like Norman Cousins and Hunter "Patch" Adams bring humour into mainstream healthcare. This research provides doctors an opportunity both now and in the future, as we learn even more about humour, to bring a softer face to medicine and truly give patients something to smile about.

Cousins N. Anatomy of an Illness. New York: WW Norton \& Company, Inc., 1979.

Paskind H. Effect of Laughter on Muscle Tone. Archives of Neurology and Psychiatry 1932; 28-3:623-628.

Robinson VM. Humor and the Health Professions. New York: McGraw-Hill, 1991.

\section{3. "Consider whether I show a man's wisdom": The enigmatic Dr. James Barry}

\section{T. Afolabi. University of Toronto, Toronto, Ont.}

No matter how thorough and diligent the approach to compiling a historical record, occasionally crucial and interesting figures are overlooked. Such is the case with Dr. James Barry.

A nineteenth Century British doctor, Barry was named inspector general of military hospitals and traveled extensively throughout the British Empire. Barry's story merits telling for both professional and personal reasons. Firstly, in the 1820 s, Barry performed what is understood to be the first Cesarean section in which both mother and child survived. However, this notable accomplishment remains absent from many accounts of the history of the cesarean section.

Far more astonishing, however, is that Barry expertly performed his role as a military doctor while somehow concealing his sex, for upon his death he was discovered to not be male.

This paper will examine how a member of the British army was able to conceal such a crucial fact during a career that spanned nearly 50 years. By revisiting army letters, nineteenth Century reports and recent developments, it will be argued that our oversight of Barry's story is due largely to two main reasons. Firstly, Barry possessed intelligence and skill that gained him the respect of colleagues and superiors alike, and allowed him to quickly rise up military ranks. This respect and high rank no doubt shielded him scrutiny and questioning. Secondly, Barry's secret was further concealed by a diplomatic and tactful doctor who, after performing a post-mortem, attempted to save face for a doctor he no doubt respected immensely. The circumstances surrounding this attempted concealment as well as the ensuing controversy are examined in this discussion of an elusive and enigmatic doctor.

Rae I. The strange story of Dr. James Barry. London: Longmans, 1958.

Kirby P. Dr. James Barry, Controversial South African Medical Figure: A recent evaluation of his life and sex. S.A. Med. J 1970; 506-516.

Kubba A, Young M. The Life, Work and Gender of Dr. James Barry MD (1795-1865). Proc. R Col. Phys. Eding. 2001; 31:352-356.

\section{Publication history of the Brugada Syndrome: Did labeling stimulate research?}

\section{M.A. Nault, A. Baranchuk, C.S. Simpson, D.P. Red- fearn, H. Abdollah, Queen's University, Kingston, Ont.}

Sudden cardiac death (SCD) in healthy young men was first recognized in 1917. Combined with an electrocardiographic (ECG) abnormality reported in 1953, 
the resulting syndrome would by 1996 eventually be recognized worldwide as Brugada Syndrome (BrS).

There is evidence that "labeling" (i.e. the process of naming a disease state or ascribing a diagnosis) alters perceptions, awareness and behaviours in medicine. Our objective was to determine whether naming a cluster of signs and symptoms as a specific syndrome raised attention given to a previously recognized though poorly defined condition as evidenced through an increase in publications. We hypothesized that naming BrS resulted in such a "labeling" stimulus.

A systematic review of the Pubmed database of indexed journals was performed to identify references to BrS between 1950 and 2006. Search terms were: "Brugada Syndrome"; "Sudden Cardiac Death AND Right Bundle Branch Block"; "Bangungot" (Filipino); "Bangungut" (Filipino); "Pok kuri" (Japanese); "Lai tai" (Thai); "Sudden Unexplained Death Syndrome"; and "SUNDS". Publications identified after 1996 by search strategies other than "Brugada Syndrome" were omitted to avoid double counting.

The search resulted in 1,042 citations. Of these, 208 occurred after 1996 and were omitted, leaving a total of 834 citations to be analyzed. Between 1950 and 1993 a total of 32 publications met the above search criteria. Thereafter, publication rate on this topic increased exponentially from 16 articles in 1994-1995 to 290 in 2005-2006.

Though numerous articles recognized either RBBB-like ECG pattern, ST segment elevation or SCD in otherwise healthy young men, it was not until publication of the 1992 Brugada and Brugada paper that the coexistence of these two conditions was recognized as a syndrome. Rising interest, as identified by publication frequency, preceded the naming of this syndrome by 4 years. This finding suggests that factors other than labeling have also contributed to the publication history of BrS.

Osher H, Wolff L. Electrocardiographic pattern simulating acute myocardial injury. Am J Med Sci 1953; 226:541-5.

Brugada P, Brugada J. Right bundle branch block, persisting ST segment elevation and sudden cardiac death: A distinct clinical and electrocardiographic syndrome. J Am Coll Cardiol 1992; 20:1391-6.

Yan G-X, Antzelevitch C. Cellular basis for the electrocardiographic J wave. Circulation 1996; 93:372-9.

\section{RESEARCH IN CONTINUING PROFESSIONAL} DEVELOPMENT - LA RECHERCHE SUR LE DÉVELOPPEMENT PROFESSIONNEL CONTINU (45-48)

\section{Education at distance: Broadcasting ECG rounds to Southeastern Ontario (BESO Project). An innovative approach for teaching elctrocardi- ography}

\section{A. Baranchuk, G. Dagnone, P. Fowler, M.N. Harrison, L. Lisnevskaia, B. Etemadi, D. Blouin, D.P. Red- fearn, C.S. Simpson. Kingston General Hospital, Queen's University, Kingston, Ont.}

Electrocardiography (ECG) interpretation is an essential skill for physicians as well as for many other health care professionals. Continuing education is necessary to maintain these skills. The process of teaching and learning ECG interpretation is complex and involves both deductive mechanisms and recognition of patterns for different clinical situations ("pattern recognition"). The successful methodologies of interactive sessions and real time problem based learning have never been evaluated with a long distance education model.

To evaluate the efficacy of broadcasting ECG rounds to different hospitals in the Southeastern Ontario region; to perform qualitative research to determine the impact of this methodology in developing and maintaining skills in ECG interpretation.

ECG rounds are held weekly at Kingston General Hospital and will be transmitted live to Napanee, Belleville, Oshawa, Peterborough and Brockville. The teaching methodology is based on real ECG cases. The audience is invited to analyze the ECG case and the coordinator will introduce comments to guide the case through the proper algorithm. Final interpretation will be achieved emphasizing the deductive process and the relevance of each case. An evaluation will be 
filled out by each participant at the end of each session.

Videoconferencing works through a vast array of internet LANs, WANs, ISDN phone lines, routers, switches, firewalls and Codecs (Coder/Decoder) and bridges. A videoconference Codec takes the analog audio and video signal codes and compresses it into a digital signal and transmits that digital signal to another Codec where the signal is decompressed and retranslated back into analog video and audio. This compression and decompression allows large amounts of data to be transferred across a network at close to real time (384 kbps with 30 frames of video per second). Videoconferencing communication works on voice activation so whichever site is speaking has the floor and is seen by all the participating sites. A continuous presence mode allows each site to have the same visual and audio involvement as the host site. A bridged multipoint can connect between 8 and 12 sites simultaneously.

This innovative methodology for teaching ECG will facilitate access to developing and maintaining skills in ECG interpretation for a large number of health care providers.

Bertsch TF, Callas PW, Rubin A. Effectiveness of lectures attended via interactive video conferencing versus inperson in preparing third-year internal medicine clerkship students for clinical practice examinations. Teach Learn Med 2007; 19(1):4-8.

Yellowlees PM, Hogarth M, Hilty DM. The importance of distributed broadband networks to academic biomedical research and education programs. Acad Psychaitry 2006;30:451-455

\section{Did the CME/CPD train leave with half the passengers? A needs assessment of Quebec special- ist associations' CPD units}

\section{G. Hudon, R. Laprise, L. Guindon. Fédération des médecins spécialistes du Québec, Montréal, Qué.}

This presentation reports on the results of a needs assessment conducted amongst the 34 Quebec specialist associations, which are accredited as CME/CPD providers by Quebec's College of Physicians, in accor- dance with the Canadian Association of Continuing Medical Education's criteria.

In 2006, a mix of methods (survey, semistructured interviews and program documentation review) were used to assess CPD units' learning needs in the areas of CME and CPD, the extent to which they carried out a list of specific tasks associated to providers' responsibilities, barriers encountered in meeting standards, and the kind of help needed to improve performance.

Although CME/CPD fields have evolved considerably in the past 20 years, results indicate that few of the advances have made their way down to the associations. The majority still provides education in the form of traditional CME, where speakers talk about new developments in medicine. Whereas the systematic approach of CME is well integrated in most units, few go beyond perceptions in their needs assessments, use problem-based learning methods, enablers, reinforcement and outcome evaluations, or help specialists self-evaluate and reflect on their practice. These methods and approaches are believed to increase CME effectiveness.

Most Canadian specialists get a large proportion of their CE from non academic medical organizations such as professional associations and learned societies. However, information available in the literature does not allow generalization of our observations to other organizations of this nature. Since non academic organizations are important CME/CPD providers, we propose that more attention be given on the way trainers are trained and innovations are shared in our CE system. What minimal knowledge and skills should be required of a CME/CPD professional today? Together with its affiliated associations and academic partners, the Federation of Medical Specialists of Quebec (FMSQ) has decided to tackle this important issue in the coming years.

Olson CA, Tooman TR, Leist JC. Contents of a core library in continuing medical education: a delphi study. JCEHP 2005; 25:278-88.

Davis DA, Thomson MA, Oxman AD, Haynes RB. Changing physician performance: a systematic review of the effect of continuing medical education strategies. JAMA $1995 ; 274: 700-5$. 
Grol R, Grimshaw J. From best evidence to best practice: effective implementation of change in patients' care. Lancet 2003; 362:1225-30.

\section{Evaluation of new implementation straegies, program effectiveness and dissemination of new padagogical knowledge: Centre for faculty devel- opment's stepping stones teaching certificate program}

\section{Richardson, I. Silver, A. Dionne. University of \\ Toronto, Toronto, Ont.}

This evaluation of the integrated Stepping Stones (SS) Teaching Certificate program, including its instructional development (workshops) and theory review (journal club) components, will inform further program development. Results of this project will also add to the limited amount of scholarly work in the area of faculty development program evaluation.

Faculty development literature in the area of organized program assessment reveals use of either quantitative OR qualitative methods. In this project, a novel method combining both techniques was used to explore program impact. Participants completed 2 questionnaires to identify skill-set knowledge gaps in teaching effectiveness. Pre- and post-program quantitative gaps were generated. Focus groups were used for qualitative exploration. Areas explored preprogram included: a) motives for enrollment, b) program expectations and c) prior teaching preparation. Post-program discussion explored: the impact of the program on a) participant's perceived gaps, b) teaching behaviour change, and c) its influence on their career in education.

We believed the program's interprofessional environment would foster development of a learning community having impact on faculty knowledge, skills and attitudes related to teaching, and potentially elicit behavioural change in teaching practices. Results from a 2004-2005 cohort of participants have identified a variety of benefits for faculty and their teaching practice. Results from a second separate cohort, 2005-2006 participants, validated the initial findings. Remarkable harmonization in the results of the qualitative analysis between the two cohort samples was evident. Statistically significant differences $(p<0.05)$ were found in each of the domains examined qualitatively.

Both qualitative and quantitatively, program effectiveness was demonstrated immediately following completion of the program. Follow up to assess the sustainability of the effects is ongoing. The analysis of the quantitative discrepancy (gaps) data has lead to a possible technique to assist in identifying unperceived educational needs.

McLeod PJ, Steinert Y, Nasmith L, Conochie L. Faculty Development in Canadian medical schools: a 10year update. CMAJ 1997; 156(10):1419-23.

Hewson MG, Copeland HL, Fishleder AJ. What's the use of faculty development? Program evaluation using retrospective self-assessments and independent performance ratings. Teach Learn Med 2001; 13(3):153-60.

Moore EM. A Framework for Outcomes Evaluation in the Continuing Development of Physicians, in: The Continuing Professional Development of Physicians. Eds. Davis D, Barnes BE, Fox R. AMA Press, 2003.

\section{MD/MBA: A useful combination in Canadian specialty medicine?}

J. Shantz. University of Manitoba, Winnipeg, Man.

The practice of medicine has changed greatly in the face of rapidly changing technology, limited or controlled funding and heightened patient expectations. In the early 1990s curricula for the management education of residents appeared. The Social Needs Working Group identified competencies grouped under the manager role as a major weakness of residency training in Canada. Recent graduates in the United States and Canada found they were unprepared for the increased responsibility of office management, contract negotiation and healthcare administration.

The popularity of masters degrees in business administration (MBA) has grown exponentially. At the same time the number of medical professionals completing MBAs in Canada is still small by comparison, as opposed to the United States where MD-MBAs are more prevalent. The utility of MBAs is still in ques- 
tion in Canada. The effects on practice patterns of $\mathrm{Ca}$ nadian residents completing an MBA is also unknown.

The following workshop aims to allow participants to experience the format of case-based learning applied in many MBA programs. The cases will also highlight the unique approach a business mind can bring to current issues within medicine. The usefulness of an MBA will also be explored through small group exercises and testimonials. The process of applying to and funding this degree will be elaborated.

Frank RA. Practice management education--are residency programs properly preparing physicians for the $21 \mathrm{st}$ Century? College review - Denver, Colo. 1993 (Fall); 10(2):22-47.

Gill JB, Schutt RC, Jr. Practice management education in orthopaedic surgical residencies. The Journal of bone and joint surgery 2007; Jan; 89(1):216-9.

Parekh SG, Singh B. An MBA: the utility and effect on physicians' careers. The Journal of bone and joint surgery 2007 (Feb); 89(2):442-7.

\section{Learning on the run - Practical strategies for physician learning}

R. Bankey, C. Campbell. Center for Learning in Practice, the Royal College of Physicians and Surgeons of Canada, Ottawa, Ontario, Canada.

As a part of the Center for Learning in Practice's (CLIP) mandate, a white paper series on topics of relevance to the educational needs of fellows was developed. The first in this series of white papers, was one entitled: Lifelong Learning White Paper - Supporting Physician Lifelong Learning: Strategies, Tools and Recommendations. This white paper focused on a variety of themes including the concept of 'learning on the run', which means that learning takes place wherever you are and occurs on a daily basis over the course of one's work routine. In other words, learning and the learning context is driven by one's practice context as well as by one's own career goals and needs. The center for learning in practice is currently producing a series of thematic monographs/booklets for physicians based on the white papers, the first of which is entitled: Learning on the run-practical strategies for physician learning. The purpose of these monographs are to assist physicians with their learning and practice needs and contain a section on how tools and programs within the Maintenance of Certification (MOC) program can enhance and contribute to physician learning strategies. This poster details the content of a draft monograph on 'learning on the run' for physicians to use and comment on. These comments will be used to refine and enhance the monograph in order for CLIP to disseminate it more widely across North America. The monograph can also be accessed under CLIP's section of the Royal College of Physicians and Surgeons of Canada website http://rcpsc.medical.org/clip/index.php

\section{RESEARCH IN RESIDENCY EDUCATION - LA RECHERCHE SUR LES ÉTUDES MÉDICALES POSTDOCTORALES (RÉSIDENCE) (49-74)}

\section{Effect of a resident-as-teacher training pro- gramme on surgical resident clinical teaching skills}

\section{Y. Ying, P. Fitzgerald, S Reid. McMaster University, Hamilton, Ont.}

This study was designed to assess the benefits of a resident-as-teacher training programme on surgical residents within a surgical clinical teaching unit.

A randomized controlled trial was conducted at McMaster University between July 2005 and June 2006. Twenty-eight (28) General Surgery Residents and one 134 Medical Students participated in the study. Residents were randomly assigned to participate in a two-day training course on clinical teaching skills at the 3 or 12-month interval. Medical Students completed teaching evaluations on residents whom they had significant exposure. Resident scores on teaching evaluations as well as medical student performance on rotation examinations were assessed.

The intervention $(n=14)$ and control $(n=14)$ groups were at similar levels of training. Only 5 intervention and 9 control residents had both pre and post intervention evaluations. Evaluations were measured on a 1 to 5 Likert scale. Data was analyzed by intention-totreat. The mean evaluation score in both control and intervention groups were higher than pre-intervention 
( $8 \%$ and $14 \%, \mathrm{p}=0.03$ ). However, the magnitude of change between the 2 groups was not statistically significant. Medical student performance by those exposed to more intervention residents was not significantly different from those exposed to more control residents.

There is a significant improvement in resident teaching over an academic year, as determined by medical student evaluations of the resident-teachers. Although there was a trend of improved teaching with the teaching- skills intervention, the difference was not statistically significant, and did not affect medical student performance on the end-of rotation examinations.

Blue AV, et al. Surgical Teaching Quality Makes a Difference. American Journal of Surgery 1999; 177:86-9.

Dunnington GL, DaRosa D. A prospective Randomized Trial of Residents-as-teachers Training Program. Academic Medicine 1998; 73: 696-700.

Griffith $\mathrm{CH}$, et al. Relationship of How Well Attending Physicians Teach to Their Students' Performances and Residency Choices. Academic Medicine 1997; 72:S118-120.

\section{Health advocacy in surgical training: A Cana- dian survey on attitudes and experience in urology residency}

\section{D.R. Siemens, M. Leveridge, D. Beiko, J.W.L. Wilson,} Queen's University, Kingston, Ont.

We sought to assess surgical residents' perceptions and attitudes toward health advocacy in residency training and practice by administering an anonymous, cross-sectional, self-report questionnaire to all final year urology residents in Canadian training programs.

The survey was closed-ended and employed a 5point Likert scale designed to assess familiarity with the concept of health advocacy and its application and importance to training and practice. Descriptive and correlative statistics were used to analyze the responses.

There was a 93\% response rate from the chief residents. Most residents were well aware of the role of health advocate in urology, and a majority (68\%) believe it to be important in residency training and in the urologist's role in practice. However, a minority (7-25\%) agreed that formal training or mentorship in health advocacy was available at their institution, and only $21-39 \%$ felt that they had employed its principles in the clinic or community. Only $4-7 \%$ or residents surveyed were aware of or had participated in local urologic health advocacy groups.

Despite knowledge and acceptance of the importance of the health advocate role, there is a perceived lack of formal training and a dearth of participation during urologic residency training.

Verma S, Flynn L, Seguin R. Faculty's and Residents' Perceptions of Teaching and Evaluating the Role of Health Advocate. Acad Med. 2005; 80:103-108.

Oandasen I. Health advocacy: bringing clarity to educators through the voices of physician health advocates. Acad Med. 2005 (Oct); 80(10 Suppl):S38-41.

Frank JR. (Ed). The CanMEDS 2005 physician competency framework. Better standards. Better physicians. Better care. Ottawa: The Royal College of Physicians and Surgeons of Canada, 2005.

\section{Structured assessment format for evaluating operative reports (SAFE-OR) in general surgery}

A. Vergis, L. Gillman, M. Taylor, S. Minor, J. Park. University of Manitoba, Winnipeg, Man., Dalhousie University, Halifax, NS.

This study determined the construct validity, interrater reliability and internal consistency of a "Structured Assessment Format for Evaluating Operative Reports" (SAFE-OR) in general surgery. The assessment instrument was developed using consensus criteria set forth by the Canadian Association of General Surgeons. It includes a structured assessment and a global quality rating scale. Residents divided into novice and experienced groups viewed and dictated a video-taped laparoscopic sigmoid colectomy. Transcriptions were then graded by blinded, independent faculty evaluators using SAFE-OR.

Twenty-one residents participated in the study. Mean structured assessment scores (out of 44) were significantly lower for novice versus experienced residents $(23.3 \pm 5.2$ vs $34.1 \pm 6.0, \mathrm{t}=0.001)$. Mean global quality scores (out of 45) were similarly lower for 
novice residents $(25.6 \pm 4.7$ vs $35.9 \pm 7.6, \mathrm{t}=0.006)$. Inter-class correlation coefficients were 0.98 (95\% CI 0.96-0.99) for structured assessment and 0.93 (95\% CI 0.83-0.97) for global quality scales. Cronbach's alpha coefficients for internal consistency were 0.85 for structured assessment and 0.96 for global quality assessment scales.

SAFE-OR demonstrates significant construct validity, excellent inter-rater reliability and high internal consistency. This tool will allow educators to objectively evaluate the quality of trainee operative reports and ultimately provide a mechanism for implementing, monitoring, and refining curriculum for operative dictation communication skills.

Moore R. The dictated operative note: important but is it being taught? Journal of the American College of Surgeons 2000; 190(5):639-40.

Novitsky Y, Sing R, et al. Prospective, blinded evaluation of accuracy of operative reports dictated by surgical residents. The American Surgeon 2005; 71(8):627-31.

Wanzel K, Ward R, et al. Teaching the surgical craft: From selection to certification. Current Problems in Surgery 2002; 39(6):573-659.

\section{Simulation based training improves resident competence in the performance of critical resusci- tation procedures}

\section{T. Langhan, I. Rigby, I. Walker, T. Donnon, D. Howes, J. Lord. University of Calgary, Calgary, Alta.}

We sought to assess the impact of procedural skills simulation training on residents' competence in performing critical resuscitation skills. Our study was a prospective, cross-sectional study of residents from three residency training programs (Family Medicine, Emergency Medicine and Internal Medicine) at the University of Calgary. Participants completed a survey measuring competence in the performance of the procedural skills required to manage hemodynamic instability. The study intervention was an 8 hour simulation based training program focused on resuscitation procedure psychomotor skill acquisition. Competence was criterion validated at the Right Internal Jugular Central Venous Catheter Insertion station by an expert observer using a standardized checklist (Observed
Structured Clinical Examination (OSCE) format). At the completion of the simulation course participants repeated the self-assessment survey. Descriptive Statistics, Cronbach's alpha, Pearson's correlation coefficient and Paired Sample t-test statistical tools were applied to the analyze the data.

Thirty-five of 37 residents (9 FRCPC Emergency Medicine, 4 CCFP-Emergency Medicine, 17 CCFP, and 5 Internal Medicine) completed both survey instruments and the eight hour course. Seventy-two percent of participants were PGY-1 or 2. Mean age was 30.7 years of age. Cronbach's alpha for the survey instrument was 0.944. Pearson's Correlation Coefficient was 0.69 ( $p<0.001)$ for relationship between Expert Assessment and Self-Assessment. The mean improvement in competence score pre- to postintervention was 6.77 ( $\mathrm{p}<0.01,95 \%$ CI 5.23-8.32).

Residents from a variety of training programs (Internal Medicine, Emergency Medicine and Family Medicine) demonstrated a statistically significant improvement in competence with critical resuscitation procedural skills following an intensive simulation based training program. Self-assessment of competence was validated using correlation data based on expert assessments.

Dawson S. Procedural simulation: a primer. J Vasc Interv Radiol. 2006; 17(2.1):205-13.

Vozenilek J, Huff JS, Reznek M, Gordon JA. See one, do one, teach one: advanced technology in medical education. Acad Emerg Med. 2004; 11(11):1149-54.

Ziv A, Wolpe PR, Small SD, Glick S. Simulation-based medical education: an ethical imperative. Acad Med. 2003; 78(8):783-8.

\section{Resident training and the dictated operative report - A national perspective}
L.M. Gillman, A. Vergis, J. Park, M. Taylor. Depart- ment of Surgery, University of Manitoba, Winni- peg, Man.

Operative dictation training is a poorly studied area of surgical resident education and there is currently no literature on the national experience with operative dictation training in Canada. We therefore undertook a web-based survey of residents and program directors 
in general surgery training programs in Canada to determine if there is an ongoing desire for formal operative dictation training.

Every resident and program director in English speaking General Surgery programs in Canada was contacted by email and asked to participate in the study. A secure, web based survey program was developed to conduct the survey and collect the data. The survey contained questions regarding comfort level with dictation, feedback on dictations and methods of dictation training employed by the individual residents and the resident training programs.

Two hundred and seventy-four residents and 11 program directors responded to the survey $(70.4 \%$ and $78.5 \%$ response rate, respectively). Among residents, 201 residents $(73.3 \%)$ reported that their dictations were in need of improvement while 191 residents $(69.7 \%)$ requested further training in dictation. Twohundred and six residents $(75.2 \%)$ reported that their training program did not employ any formal methods to help improve their dictations. Furthermore, 153 residents $(55.8 \%)$ had never received feedback on their dictations.

Ten program directors $(90.9 \%)$ felt that residency programs should include formal training in operative dictation. Unfortunately, half of these program directors could not identify any formal methods currently being employed in their training programs, this despite the fact that $45.5 \%$ of program directors could identify specific instances where direct patient care was negatively affected by a poor operative report.

Both program directors and residents identified operative dictation templates and formal feedback on dictations as the two interventions they would like to see instituted to improve operative dictations in their residency training programs.

Residents and program director recognize a need for the development of formal operative dictation training in Canada.

Eichholz AC, Van Voorhis BJ, Sorosky JI, Smith BJ, Sood AK. Operative note dictation: should it be taught routinely in residency programs? Obstetrics and Gynecology 2004; 103:342-6.
Menzin AW, Spitzer M. Teaching operative dictation. A survey of obstetrics/gynecology residency program directors. Journal of Reproductive Medicine 2003; 48:850-2.

Moore RA. The dictated operative note: important but is it being taught? Journal of the American College of Surgeons 2000; 190:639-40.

\section{Assessing cardiac physical examination comet- ence using simulation technology and real patients}

G. Cole, R. Hatala, S.B. Issenberg, B. Kassen, C.M. Bacchus, R.J. Scales. University of British Columbia, Vancouver, BC, University of Miami, Miller School of Medicine Centre for Research in Medical Education, Miami, FL, Royal College of Physicians and Surgeons of Canada, Ottawa, Ont., University of Calgary, Calgary, Alta.

Assessment of residents' physical examination skills often involves the use of standardized patients lacking physical abnormalities. Simulation technology offers the potential benefit of mimicking physical abnormalities. The current study was undertaken to examine the relationship between physicians' competence in cardiac physical examination as assessed using simulation technology compared to real patients.

An OSCE was created using 3 modalities of cardiac patients: real patients (RP) with cardiac abnormalities, standardized patients (SP) combined with a computer-based audio-video simulation of auscultatory abnormalities and a cardiopulmonary patient simulator (CPS). The same four cardiac diagnoses were tested with each modality.

Participants were 28 internists, within 3 years of passing the Royal College of Physicians and Surgeons of Canada's (RCPSC) Comprehensive Examination in Internal Medicine. At each station, two RCPSC examiners independently rated a participant's physical examination technique and provided a global rating of clinical competence. The accuracy of a participant's cardiac diagnosis for each patient was scored separately by two investigators.

The inter-rater reliability between examiners, for the global rating outcome, was 0.76 for RP stations, 0.78 for SP stations and 0.75 for CPS stations. The correlations between participants' global ratings on 
each modality were: RP vs. SP, r=0.19; RP vs. CPS, $\mathrm{r}=0.22$; SP vs. CPS, $\mathrm{r}=0.57(\mathrm{p}<0.01)$.

A number of methodological limitations were highlighted during the study, including difficulties in truly matching patients within and between modalities, differential weighting of components into the examiners' global ratings based on modality and limitations of case specificity. No modality provided a clear "gold standard" to assess residents' cardiac physical examination competence. In the context of assessment, until these limitations are addressed, simulation modalities may not be directly interchangeable with real patients.

Boulet JR, Swanson DB. Psychometric challenges of using simulations for high-stakes assessment. In: Dunn WF (ed). Simulators in critical care education and beyond. Des Plaines, IL: Society of Critical Care Medicine 2004; 11930.

Hatala R, Kassen BO, Nishikawa J, Cole G, Issenberg SB. Incorporating simulation technology in a Canadian national specialty examination: a descriptive report. Academic Medicine. 2005; 80(6):554-6.

Issenberg SB, McGaghie WC, Petrusa ER, Gordon DL, Scalese RJ. Features and uses of high-fidelity medical simulations that lead to effective learning: a BEME systematic review. Med Teach. 2005; 27(1):10-28.

\section{Simulation based training of technical surgical skills: A review of a five-year collaborative research program supported by the RCPSC medical educa- tion fund}

A. Dubrowski, V. LeBlanc, W. Gofton, G. Xeroulis, H. Carnahan. University of Toronto, Toronto, Ont., University of Ottawa, Ottawa, Ont., University of Western Ontario, London, Ont.

During the past five years, with support from the RCPSC, a collaborative group of researchers conducted projects investigating issues related to simulation based training of technical surgical skills. The aim of this presentation is to review the body of work generated, its significance, and outline future research plans.

In all studies, participants were medical students and residents from 3 medical schools in Ontario. First, we successfully demonstrated that trainees benefit from simulation-based practice by improving their ability to multitask. This ability not only increases technical proficiency, but also results in an enhanced ability to learn other aspects of surgery. Second, we showed that the adaptation of learning theories helps in optimizing training curricula by matching the fidelity of a simulator to the trainees' level of expertise. Third, we provided validation of both expert and computer based methods for assessment. We showed that computer based assessments are sufficient for the evaluation of trainees learning fundamental skills, while expert based measures are more effective in the evaluation of performance on complex technical skills. Finally we demonstrated that examinationinduced stress has a facilitating effect on trainees' skills performance.

This body of research lends support for the inclusion of a simulation based approach to training technical skills. It also highlights the importance of the choice of assessment methods. Collectively this work highlights the need for further research in the optimization of training methods by the incorporation of learning theory into the existing training curricula. Related to this, further research in our laboratory will investigate the effects of practice schedule and expert feedback, as well as the role of self-regulated practice in the acquisition of technical surgical skills.

Xeroulis GJ, Park J, Moulton CA, Reznick RK, Leblanc V, Dubrowski A. Teaching suturing and knot-tying skills to medical students: a randomized controlled study comparing computer-based video instruction and (concurrent and summary) expert feedback. Surgery 2007; 141(4):442-9.

Brydges R, Sidhu R, Park J, Dubrowski A. Construct validity of computer-assisted assessment: quantification of movement processes during a vascular anastomosis on a live porcine model. Am J Surg. 2007; 193(4):523-9.

Brydges R, Carnahan H, Backstein D, Dubrowski A. Application of motor learning principles to complex surgical tasks: searching for the optimal practice schedule. J Mot Behav. 2007; 39(1):40-8. 


\section{Proficiency at the end of practice predicts re- tention of a technical clinical skill}

\section{H. Carnahan, E. Hagemann, A. Dubrowski. University of Toronto, Toronto, Ont.}

A debate is emerging regarding the efficacy of proficiency based versus duration based training of technical skills. It is not clear whether the performance level attained at the end of practice (i.e., proficiency criteria), or the overall amount of practice performed during learning will best predict the retention of a technical clinical skill.

The skill learned was the single-handed double square-knot. Forty two trainees learned the skill through video-based instruction and were divided into three groups (14 participants per group) each with a specific criterion time to tie the knot $(10,15$, and 20 seconds). Practice continued until participants completed the knot within their criterion time. The total number of trials, and the overall practice time required to obtain each respective criterion were recorded during practice. Participants returned one-week later for a timed retention test consisting of one trial of the knot tying skill with no video instruction.

A multiple regression analysis tested whether the amount of practice, the total practice time, or the criterion reached at the end of practice was the best predictor of the time taken to perform the skill during retention. This analysis showed that the number of practice trials was highly correlated with total practice time ( $\mathrm{r}$ $=.82, \mathrm{p}=.01$ ), therefore total practice time was withdrawn as a predictor variable from the subsequent analysis. The regression showed that the only significant predictor of retention performance was the criterion reached at the end of practice $(\mathrm{p}=.03)$. The number of practice trials was not found to significantly predict the retention performance $(\mathrm{p}=.87)$.

The results support the notion that proficiency based training results in better retention of a technical clinical skill in comparison to duration based approaches. This provides evidence for the introduction of proficiency based educational approaches in technical skills curricula.
Jowett N, LeBlanc V, Xeroulis G, MacRae H, Dubrowski A. Surgical skill acquisition with self-directed practice using computer-based video training. Am J Surg. 2007; 193(2):237-42.

Gallagher AG, Ritter EM, Champion H, Higgins G, Fried MP, Moses G, Smith CD, Satava RM. Virtual reality simulation for the operating room: proficiency-based training as a paradigm shift in surgical skills training. Ann Surg. 2005; 241(2):364-72

Van Sickle KR, Ritter EM, McClusky DA, Lederman A, Baghai M, Gallagher AG, Smith CD. Attempted establishment of proficiency levels for laparoscopic performance on a national scale using simulation: the results from the 2004 SAGES Minimally Invasive Surgical Trainer-Virtual Reality (MIST-VR) learning center study. Surg Endosc. 2007; 21(1):5-10.

\section{The power of power: comparative evaluations of medical residency training across teaching sites and programs at the University of Toronto}

\section{Abrahams, S. Verma, L. Muharuma, K. Imrie, R. Vestemean, K. Imrie, P. Poldre, J. McIlroy, N. Woods. University of Toronto, Toronto, Ont.}

To meet accountability and accreditation requirements, teaching partners and the faculty postgraduate office required more robust and integrated feedback on teaching and assessment. The web-based evaluation system known as POstgraduate Web Evaluation and Registration (POWER) was implemented in 2004/ 05 by most residency training programs, using their existing forms and scoring scales. At start up, over 250 different evaluation forms and 85 varying scoring scales were in operation across programs for the InTraining Evaluation Reports (ITERs) and residentcompleted evaluations for Rotation Evaluation Scores (RES) and Teaching Effectiveness Scores (TES).

The POWER Evaluation Working Group was formed to develop a methodology to gather and consolidate evaluations to report on medical residents, their teachers, and rotations in a clear, consistent userfriendly format, map general questions against CanMEDS roles and Family Medicine principles, and convert all scoring scales to a consistent 5 point Likert 
scale. A standardized naming protocol was developed to map rotation services to individual teaching sites.

The 2004/05 analysis of these evaluations (2004/ 05 Annual POWER Report: Lessons Learned) provide baseline data to begin monitoring trends in resident and faculty performance, assess the quality of programs and identify areas for improvement by CanMEDS standards and CFPC principles. Mean scores, standard deviations and number of evaluations were presented by teaching site and program.

Consolidation of evaluations by program and teaching site provides valuable feedback to hospitals and programs wishing to standardize and improve their assessment systems, and to postgraduate medical offices who must maintain evaluation standards and illustrate trends for accreditation purposes. Future activities include: standardizing evaluation forms starting July 2007, improving scoring consistency and accuracy, improve participation rates and timeliness of responses, develop a procedure/case log tracking system, and trend analysis.

Afrin LB, Arana GW, Medio FJ, Ybarra AF, Clarke HS Jr. Improving oversight of the graduate medical education enterprise: one institution's strategies and tools. Academic Medicine 2006 (May); 81(5):419-25.

Benjamin S, Robbins LI, Kung S. Online Sources for assessment and evaluation. Academic Psychiatry 2006 (Nov-Dec); 30(6):498-504.

Rosenberg ME, Watson K, Paul J Miller W, Harris I, Valdivia TD. Development and Implementation of a webbased evaluation system for an internal medicine residency program. Academic Medicine 2001 (Jan); 76(1):92-5.

\section{Stories - Structured operative reporting in en- teric surgery}

L.M. Gillman, A. Vergis, J. Park, S. Minor, M. Taylor. Department of Surgery, University of Manitoba, Winnipeg, Man.

The purpose of this study was to determine whether the introduction of a Standardized Operative Dictation Template improved the quality of resident dictation.

General surgery residents $(\mathrm{N}=20)$ from the University of Manitoba participated in the study. All residents were shown a standardized surgical proce- dure video and then asked to dictate an operative report. Residents were randomized with the intervention group receiving the Operative Dictation Template. Three months later, all residents were retested. Resident comfort level with dictation and satisfaction with the template was evaluated with a questionnaire. Dictations were evaluated by two blinded independent reviewers using the previously validated SAFE-OR assessment tool. This tool consists of a Structured Assessment Form (SAF) scored out of 45 and a Global Quality Ratings Scale (GQRS) out of 36. Pre and post scores were analyzed using a two-tailed Wilcoxon signed rank test.

Subjective comfort level with dictation, as measured by responses on a five point Likert scale, improved significantly in the intervention group $(\mathrm{p}=0.02)$. In addition, $90 \%$ of residents in the intervention group subjectively reported their dictations improved because of the template. There was no overall difference in the quality of dictation in the intervention group pre and post intervention as measured by the SAF (28.6 vs. 30.0; $\mathrm{p}=0.36)$ and GQRS (21.7 vs. 21.8, $\mathrm{p}=0.96$ ). However, junior resident subgroup analysis revealed statistically significant improvement in the intervention on both the SAF (23.2 vs. 28.3; $\mathrm{p}=0.02$ ) and GQRS (17.1 vs. 20.4; $\mathrm{p}=0.02)$. Senior resident subgroup analysis showed no difference in the intervention group on either the SAF (36.8 vs. 32.4; $\mathrm{p}=0.07)$ and GQRS (28.5 vs. 23.9; $\mathrm{p}=0.07)$.

The Operative Dictation Template can result in a significant improvement in resident comfort level with dictation and has the potential to improve the quality of junior resident dictations.

Eichholz AC, Van Voorhis BJ, Sorosky JI, Smith BJ, Sood AK. Operative note dictation: should it be taught routinely in residency programs? Obstetrics and Gynecology 2004; 103:342-6.

Menzin AW, Spitzer M. Teaching operative dictation. A survey of obstetrics/gynecology residency program directors. Journal of Reproductive Medicine 2003; 48:850-2.

Moore RA. The dictated operative note: important but is it being taught? Journal of the American College of Surgeons 2000; 190:639-40. 


\section{General medicine residents' perception of the mini-CEX}

\section{S. Malhotra, R. Hatala, C.-A. Courneya. Department of Medicine, St. Paul's Hospital, University of British Columbia Faculty of Medicine, Vancouver, BC.}

The mini-CEX is a 30 minute observed clinical encounter. It can be done in the outpatient, inpatient or emergency room setting. It strives to look at several parameters including a clinical history, physical, professionalism and overall clinical competence. Trainees are rated using a 9-point scoring system: 1-3 unsatisfactory, 4-6 satisfactory and 7-9 superior.

Eight months after the introduction of the miniCEX to the core University of British Columbia Internal Medicine Residents, a one hour semi-structured focus group for residents in each of the three years took place. The focus groups were conducted by an independent moderator, audio-recorded and transcribed.

Using a phenomenological approach the comments made by the focus groups participants were read independently by three authors, organized into major themes. In doing so, several intriguing common patterns were revealed on how General Medicine Residents perceive their experience in completing a mini-CEX.

The themes include Education, Assessment and Preparation for the Royal College of Physicians and Surgeons Internal Medicine exam. Resident learners perceived that the mini-CEX process provided insight into their clinical strengths and weaknesses. Focus group participants favored that the mini-CEX experience will benefit them in preparation, and successful completion of their licensing exam.

Daelmans HE, Overmeer RM, van der Hem-Stockroos $\mathrm{HH}$, Scherpbier AJ, Stehouwer CD, van der Vleuten CP. In-training assessment: qualitative study of effects on supervision and feedback in an undergraduate clinical rotation. Medical Education 2006; 40(1):51-8.

De Lima AA, Henquin R, Thierer J, Paulin J, Lamari S, Belcastro F, Van der Vleuten CPM. A qualitative study of the impact on learning of the mini clinical evaluation exer- cise in postgraduate training. Medical Teacher January 2005; 27(1):46-52.

DiCicco-Bloom B, Crabtree BF. The Qualitative Research Interview. Medical Education 2006; 40:314-32.

\section{Using a pocket card to improve end-of-life care on clinical teaching units: A controlled trial}

\section{J. Downar, J. Mikhael. University of Toronto, Toronto, Ont.}

Although palliative and end-of-life is a critical part of in-hospital medical care, residents often have very little formal education in this field. To determine the efficacy of a symptom management pocket card in improving the comfort level and knowledge of residents in delivering end-of-life care on medical clinical teaching units, we performed a controlled trial involving residents on three clinical teaching units.

Residents at each site were given a 5-minute questionnaire at the start and at the end of their medicine ward rotation. Measures of self-reported comfort levels were assessed, as were 5 multiple-choice questions reflecting key knowledge areas in end-of-life care. Residents at all three sites were given didactic teaching sessions covering key concepts in palliative and end-of-life care over the course of their medicine ward rotation. Residents at the intervention site were also given a pocket card with information regarding symptom management in end-of-life care.

Over 10 months, 137 residents participated on the three clinical teaching units. Comfort levels improved in both control $(\mathrm{p}<0.01)$ and intervention groups $(\mathrm{p}<0.01)$, but the intervention group was significantly more comfortable than the control group at the end of their rotations $(z=2.77, p<0.01)$. Knowledge was not significantly improved in the control group $(\mathrm{p}=0.07)$, but was significantly improved in the intervention group $(\mathrm{p}<0.01)$. The knowledge difference between the two groups approached but did not reach statistical significance at the end of their rotation.

In conclusion, our pocket card is a feasible, economical educational intervention that improves resident comfort level and knowledge in delivering endof-life care on clinical teaching units. 
Oneschuk D, Moloughney B, Jones-McLean E, Challis A. The Status of Undergraduate Palliative Medicine Education in Canada: a 2001 Survey. Journal Palliative Care 2004; 20:32.

Tiernan E, Kearney M, Lynch AM, Holland N, Pyne P. Effectiveness of a teaching programme in pain and symptom management for junior house officers. Support Care Cancer 2001; 9:606-610.

Okon TR, Evans JM, Gomez CF, Blackhall LJ. Palliative Educational Outcome with Implementation of PEACE Tool Integrated Clinical Pathway. Journal of Palliative Medicine 2004; 7:279-295.

\section{Primary ophthalmic care patterns and training of University of Ottawa residents}

\section{E.A. Sogbesan, A. Fournier, K. Damji. University of Ottawa Eye Institute, Ottawa, Ont.}

This study assessed whether residents are equipped to perform recommended standards of ophthalmic primary care and determined if the findings reflect the adequacy of their undergraduate and postgraduate teaching in ophthalmology. Information was collected using web based online questionnaire that was completed by residents in the residency program at the University of Ottawa. Data was extracted and analyzed using Epi Info software.

One hundred and sixteen residents $(17 \%$ capture rate) in all years of training completed the online questionnaire. Majority of the residents were not familiar with the different vision screening guidelines, less so with the Canadian $(63-97 \%)$ than the American guidelines $(91-94 \%)$. This was reflected in their referral patterns and mixed results of ophthalmic knowledge assessments. Only $21 \%$ of respondents were highly confident or confident in dealing with patients with eye problems. However, most were confident in history taking, visual acuity assessment and examination, but less so with ophthalmoscopy and intraocular pressure measurements.

The duration of undergraduate ophthalmic clerkship was at least one week in most of the institutions. However, about one third of the residents surveyed did not have any ophthalmology clerkship in medical school. Only 33\% felt that their clerkship was ade- quate and about the same proportion felt that they received adequate ophthalmic exposure of relevance to their current practice. About $90 \%$ of the residents have not attended an update course in ophthalmology. Over $75 \%$ of the residents thought that a continuing education program in Ophthalmology would be useful and would be interested in attending such a program in the future.

Opportunities exist to address these inadequacies to better prepare residents for clinical practice. These include improvements in undergraduate ophthalmic education, inclusion of ophthalmology electives in residency training programs and the development of a continuing education program in ophthalmology for primary eye care physicians.

US Preventive Services Task Force: Screening for visual impairment in Children younger than five years: recommendation statement. American Family Physician 2005; 71(2): 333-340.

Feightner JW. Routine preschool screening for visual and hearing problems. In: Canadian Task Force on the Periodic Health Examination. Canadian guide to clinical preventive health care. Ottawa: Health Canada, 1994:298-304.

Bellan L. Ophthalmology undergraduate education in Canada. Can J Ophthalmol. 1998; 33(1):3 - 7.

\section{2. does an expert presentation raise awareness of CanMEDs roles among residents?}

\section{S. Jenkins, K. Crocker, P. Jeon, M. Borgaonkar, D.}

Pace, S. Verma. Memorial University of Newfoundland, St. John's, NL.

We set out to determine whether an expert presentation on CanMEDS would raise awareness of CanMEDS roles among residents. We addressed this question with paired surveys distributed before and after the expert presentation.

Each survey outlined seven different clinical scenarios each of which required one of the seven core CanMEDS competencies. Paired surveys were distributed prior to the presentation to the audience that was composed of a selection of residents from various disciplines. One survey was filled out prior to and the second survey completed following the expert presentation. 
Data were analysed using nonparamentric statistical methods. There was in general, a low prepresentation background knowledge of CanMEDS roles, with wide variability between specialties. Our hypothesis that disciplines with less patient contact would have less understanding of CanMEDS roles was not fully supported. All specialties demonstrated improvement in their understanding of CanMEDS roles in the post-presentation survey.

While there is a low background level of knowledge about CanMEDS roles, we determined that following an expert presentation (in this case by Dr. Serita Verma) the residents were significantly more able to correctly apply the core competencies of the CanMEDS model to the given clinical scenarios. We propose that an expert presentation could be applied as an innovative educational tool advancing CanMEDS education among residents.

\section{Developing a program for resident wellness at the postgraduate medical education office, University of Toronto}

\section{S. Edwards, S. Verma, R. Zulla. Postgraduate Medical} Education Office, Faculty of Medicine, University of Toronto, Toronto, Ont.

Prevalence of stress-related mental health problems in residents is equal to, or greater than, the general population. Medical training has been identified as the most significant negative influence on resident mental health. At the same time, residents possess inadequate stress management and general wellness skills and poor help-seeking behaviours. Unique barriers prevent residents from self-identifying and seeking assistance. Stress management programs in medical education have been shown to decrease subjective distress and increase wellness and coping skills.

The University of Toronto operates the largest postgraduate medical training program in the country. The Director of Resident Wellness position was created in the Postgraduate Medical Education Office to develop a systemic approach to resident wellness that facilitates early detection and intervention of signifi- cant stress related problems and promote professionalism.

Phase One of this new initiative has been to highlight its presence to residents and program directors by speaking to resident wellness issues at educational events. Resources on stress management, professional services, mental health, and financial management have been identified and posted on the postgraduate medical education website and circulated to program directors. Partnerships have been established with physician health professionals, the University of Toronto, and the Professional Association of Residents and Internes of Ontario. Research opportunities for determining prevalence and effective management strategies for stress related problems are being identified and ultimately programs/resources will be implemented to ensure that resident have readily accessible resources.

The establishment of a Resident Wellness Strategy from its embryonic stags and the challenges faced are presented as a template for implementing similar programs at other medical schools.

Earle L, Kelly L. Coping Strategies, Depression and Anxiety among Ontario Family Medicine Residents. Canadian Family Physician 2005; 51:242-3.

Cohen J, Patten S. Well-being in residency training: a survey examining resident physician satisfaction both within and outside of residency training and mental health in Alberta. BMC Medical Education; 5(21).

Levey RE. Sources of stress for residents and recommendations for programs to assist them. Academic Med 2001; 70(2):142-150.

\section{International child health (ICH) education in Canadian paediatric residency programs}

\author{
T. Audcent, H. MacDonnell, J. Brenner, L. Samson. \\ University of Ottawa, Ottawa, Ont.
}

A national survey was conducted of current ICH exposure and curriculum in pediatric residency programs. Our objectives were to quantify ICH teaching presently occurring, to identify how programs support trainees in undertaking $\mathrm{ICH}$ electives during their training, to determine attitudes towards ICH amongst paediatric program directors and chief residents across 
the country, and to identify barriers to ICH curriculum expansion within the post-graduate programs.

A population census of all 44 chief residents and program directors from the 16 Canadian pediatric programs was undertaken. A self-administered survey was developed de novo for this study. Twenty-two qualitative and quantitative questions were developed under the following domains: demographics, program content, electives, attitudes and perceptions, barriers and future directions. Surveys were completed electronically. Descriptive statistics were used, and common themes were extracted from qualitative responses.

The response rate was $65 \%$ (29 surveys), with $81 \%$ of the training programs represented. Seventythree percent of the program directors, and $44 \%$ of the chief residents from across the country responded. Eighty-nine percent reported that their program did not have a formal curriculum in ICH. All respondents reported some ICH related educational sessions, however certain areas felt to be key were lacking. $80 \%$ agreed that electives should be encouraged as part of residency training, but $72 \%$ indicated lack of adequate funding for these electives. Overall, $86 \%$ agreed that $\mathrm{ICH}$ issues are important for paediatric trainees and $84 \%$ indicated that more emphasis should be placed on ICH in the paediatric resident curriculum. Eightysix percent of respondents agreed that their program would be interested in new initiatives regarding $\mathrm{ICH}$.

The results of this survey demonstrate that although there are opportunities for ICH exposure in most paediatric training programs, formalized curriculum is lacking. The majority of programs indicated a willingness to support the integration of an ICH curriculum into their core educational components.

The Association of Faculties of Medicine of Canada (AFMC). Towards a Medical Education Relevant to All : The Case for Global Health in Medical Education. A Report of the Global Health Resource Group. April 2006.

Bateman C, et al. Bringing global issues to medical teaching. Lancet, 2001; 358:1539-42.

Edwards R, et al. Understanding global health issues: are international health electives the answer? Medical Education, 2004; 38:688-690.

\section{Concurrent pursuit of degrees and courses dur- ing community medicine residency: Challenges, policies and procedures}

\author{
M.L. Russell, A. Robinson Vollman, T. Strudsholm. \\ University of Calgary, Calgary, Alta.
}

We describe the policies and practices of Canadian Community Medicine (CM) residency programs regarding the Royal College requirement for one year of academic course work.

We surveyed 10 Program Directors (PD) of the 11 Canadian $\mathrm{CM}$ residency programs (excluding our university) by either telephone interview or written completion of a structured interview guide. Questions addressed: what is currently allowed and/or encouraged; the policies in place; and the benefits and challenges to concurrent pursuit of degrees by $\mathrm{CM}$ residents. Of particular interest were policies regarding residents studying off-site and what actions PDs take if courses or degrees desired by a resident were not available at the home university.

Seven of 10 PDs replied. Most programs did not have written policies to deal with requests to study off-site; decisions were made on a case-by-case basis. When approved, residents received salary support and bore all costs of off-site education. Several CM programs require degree acquisition during the academic year; others encourage degree acquisition. While CM program websites indicate degree completion is possible within one calendar year, often practicum placements run concurrently with resident clinical rotations or projects are competed during residency rotations. Most programs prefer residents to stay on campus for their contribution to rounds and on-call, socialization of the cohort, and continuity.

It would be helpful to programs generally if PDs had policies to guide decisions; it would be particularly useful for the specialty if this were (to the degree possible) a common policy across universities. PDs and universities wish to make academic learning more readily accessible. We suggest a focus on the development of quality distance learning and innovative strategies to share course development and improve 
residents' access to learning without the need to go off-site.

Zweifler J, Evans R. Development of a residency/MPH Program. Fam Med 2001; 33(6):453-8.

Tilak GS, Baker SR. Self-subsidization of educational expenses by senior radiology residents. Acad Radiol 2007; 14:105-9.

Walter DA, Rosenquist PB, Bawtinhimer G. Distance learning technologies in the training of psychiatry residents; a critical assessment. Acad Psychiatry 2004; 28(10):60-5.

\section{Innovation in the academic half-day CanMEDS medical expert competency for residency education}

\author{
K. Stobart, H.R. Rajani, C. Good. University of Al- \\ berta, Edmonton, Alta.
}

Over the past decade we have attempted various iterations of the academic half-day, but recurring trainee complaints of only didactic sessions, a parallel resident-directed "Nelsons" rounds, and low attendance necessitated a reconsideration of the approach.

After discussion with the postgraduate trainees we divided the academic year into two blocks. An initial 8 week "summer program" with 24 student contact hours, focuses on the introduction to and review of common, critical care and emergency pediatric issues. The following 40 weeks has 120 student contact hours. Two thirds of the time is directed at the CanMEDS Medical Expert Core Competency. The postgraduate trainees have developed a three year core knowledge curriculum. The 200 "core" topics are mapped onto four international curricula; the RCPSC's Objectives of Training and Specialty Training Requirements in Pediatrics using the SystemsBased Educational Objectives in the Core Program in Pediatrics, the American Board of Pediatrics - General Pediatrics Outline, and the Royal College of Pediatrics \& Child Health (RCPCH) Framework of Competencies for Basic Specialist Training, and Core Higher Specialist Training in Paediatrics.

The two hour Medical Expert session is divided equally into a postgraduate trainee didactic presentation, and a collaborator case-based learning session. Six weeks prior to the scheduled session the trainee and the assigned faculty collaborator receive the core Medical Expert topic mapped to the four international curricula. The pediatric trainee develops a didactic presentation along with a two page summary. The collaborator, a resource for the trainee's didactic presentation, develops three clinical cases that emphasize core knowledge, and attends as a Medical Expert resource person.

We are currently surveying the postgraduate trainees and faculty about this international-based core medical expert program of study.

\section{Loving your child to death: Consideration of the care of chronically ill children and euthanasia in Emil Sher's Mourning Dove and implications for medical education}

K. Mukhida. University of Toronto, Toronto, Ont.

How do parents cope when their child is ill or dying, when he or she experiences constant pain or suffering? What do parents think of the contributions that medical professionals make to the care of their chronically or terminally ill child? Is it possible for a parent to love a child so much that the child is wished dead? The purpose of this paper is to explore those questions and aspects of the care of chronically or terminally ill children using Mourning Dove's portrayal of one family's attempt to care for their ill daughter. A play written by Canadian playwright Emil Sher, Mourning Dove is based on the case of Saskatchewan wheat farmer Robert Latimer who killed his 12 year old daughter Tracy who suffered with cerebral palsy and lived in tremendous pain. Rather than focusing on the medical or legal aspects of the care of a chronically ill child, the play offers a glimpse into how a family copes with the care of such a child and the effects the child's illness has on a family. Reading and examination of non-medical literature, such as Mourning Dove, therefore serve as a useful means for medical professionals to better understand how illness affects and is responded to by patients and their families. This understanding is a prerequisite for them to be able to provide complete care of children with chronic or terminal illnesses and their families. 
Nuutila L, Salanterä S. Children with long-term illness: parents' experiences of care. J Pediatr Nurs 2006; 21(2):153-160.

Sharman M, Meert KL, Sarnaik AP. What influences parents' decisions to limit or withdraw life support? Pediatr Crit Care Med 2005; 6(5):513-518.

Steele R. Strategies used by families to navigate uncharted territory when a child is dying. J Palliat Care 2005; 21(2):103-110.

\section{The resident experience in a large urban teach- ing setting: Results of the 2005-2006 resident exit survey, University of Toronto}

\author{
N. Tenn-Lyn, S. Verma, R. Zulla. University of \\ Toronto, Toronto, Ont.
}

We developed and implemented an annual online survey to administer to residents exiting residency training in order to (1) assess the quality of the residency experience and (2) identify areas of strength and areas requiring improvement. Long-term goals include program planning, policy-making and maintenance of quality control. Survey content was developed from an environmental scan, pre-existing survey instruments, examination of training criteria established by the CFPC and the CanMEDS criteria established by the RCPSC. The survey included evaluation benchmarks and satisfaction ratings of program director and faculty, preparation for certification and practice, quality of life, quality of education, and work environment.

The response rate was $28 \%$. Seventy-five percent of respondents were exiting from Royal College training programs. Results of descriptive statistics determined that the overall educational experience was rated highly, with $98.9 \%$ of respondents satisfied or very satisfied with their overall patient care experience. Ninety-six percent of respondents were satisfied or very satisfied with the overall quality of teaching. Preparation for practice was identified as needing improvement, with $26 \%$ and $34 \%$ of respondents giving an unsatisfactory rating to career guidance and assistance with finding employment, respectively. Although $80 \%$ of respondents reported receiving ongoing feedback and $84 \%$ discussed their evaluations with their supervisors, only $38 \%$ of evaluations were completed by the end of the rotation.

The results indicate that residents are generally satisfied with their experiences during residency training, especially with their overall educational experience. Areas of improvement include preparation for practice and timeliness of evaluations. Further iterations of this survey are needed to refine the instrument, identify data trends and maintain quality control in residency training programs.

Frank JR (ed.). The CanMEDS competency framework: better standards, better physicians, better care. Ottawa: The Royal College of Physicians and Surgeons of Canada, 2005.

Merritt, Hawkins and Associates. Summary Report: 2003 Survey of final-year medical residents. http://www.merritthawkins.com/pdf/MHA2003residentsurv .pdf. Accessed May 1, 2006.

Regnier K, Kopelow M, Lane D, Alden A. Accreditation for learning and change: Quality and improvement as the outcome. The Journal of Continuing Education in the Health Professions 2005; 25:174-182.

\section{International medical graduates (IMGs) needs assessment study: A comparison between curren IMG trainees and program directors}

\section{S. Verma, R. Zulla, M. Otto Baerlocher. Postgraduate Medical Education Office, Faculty of Medicine, University of Toronto, Toronto, Ont.}

A needs assessment study was conducted to explore the types of issues or challenges IMG trainees encounter and the experiences of Program Directors with teaching this unique group. Both groups were asked to rate the importance of a series of issues in a horizontal curriculum using a 5-point Likert Scale. These issues fell under one of the following categories: Clinical Skills and Knowledge, Other Skills, Communication and Working Relationships, Macro Issues and Other Work-Related Issues. The scale was then collapsed to a 3-point Likert scale. Results were used to develop a horizontal curriculum for incoming IMGs to help ease their transition into residency training within the Canadian context. 
The majority of program directors (93\%) and IMG trainees $(63 \%)$ surveyed agreed that a horizontal curriculum for IMGs should be developed. Program Directors indicated that basic clinical skills and communication with team members were important to include (79\% and $90 \%$, respectively). IMGs felt that Marco Issues were importance in a horizontal curriculum, namely an orientation about the Canadian healthcare system and site hospitals $(71 \%$ and $59 \%$, respectively), followed by communication with patients (67\%). Significant differences were found with regards to the inclusion of communication with other residents and the inclusion of orientation sessions on the Canadian Health Care System and site hospitals.

These findings demonstrate there is a need for a core IMG curriculum. There is a slight disparity regarding what specific topics to include but a consensus between both groups exists on the primary domains of communication, inclusion of specialty specific skills and knowledge as well as professional interaction.

Kraemer M. Educational Challenges of International Medical Graduates in Psychiatric Residents. Journal of the American Academy of Psychoanalysis and Dynamic Psychiatry 2006; 34(1):163-171.

Whelan GP. Coming to American: The integration of the International Medical Graduates into the American Medical Culture. Academic Medicine 2005; 81(2):176-178.

Majumdar, B, Keystone JS, Cuttress LA. Cultural Sensitivity Training among Foreign Medical Graduates. Medical Education 1999; 33:177-184.

\section{Supporting IMG integration into residency training}

S. Glover Takahashi, M. Alameddine, D. Martin, S. Verma, S. Edwards. University of Toronto, Toronto, Ont.

This paper is describes the design, development, implementation and evaluation of a preparatory training program for international medical trainees. The program was offered for one week full time shortly before they begin their residency training programs. First the paper reports on the survey and focus groups that guided the learning objectives and the course con- tent. Next the paper describes the curriculum development phase and reports on the topical themes, session goals and objectives and learning materials. Three main themes emerged when developing the program: understanding the educational, health and practice systems in Canada; development of communication skills; and supporting personal success in residency training including self assessment, reflection and personal wellness. Sample lesson plans and handouts from each of the theme areas are illustrated. The comprehensive evaluation of the sessions and the overall program is then also described. The paper then summarizes the identified key issues and challenges in the design and implementation of a preparatory training program for international medical trainees before they begin their residency training programs.

Allan GM, Manca D, Szafran O, Korownyk C. Workforce issues in general surgery. Am Surg. 2007 Feb; 73(2):100-8.

Dauphinee, WD. The circle game: understanding physician migration patterns within Canada. Acad Med. 2006 (Dec); 81(12 Suppl):S49-54.

Spike NA. International medical graduates: the Australian perspective. Academic Medicine. 2006 (Sept); 81(9):842-6.

\section{Are video interviews a good alter-narative to in person interviews in assessing international appli- cants'skills?}

\section{Alameddine, K. Imrie, S. Akers, S. Verma. University of Toronto, Toronto, Ont.}

We developed and administered two questionnaires to assess the interview experience of both interviewers and applicants during postgraduate medical selection interviews. Using a 5 point likert scale, the questionnaires assessed three areas (1) ability to show/assess communication, interpersonal and problem solving skills; (2) ability to know the other side well and (3) level of comfort with the interview. Interviewers and applicants were asked to provide a global rating for the interview. The questionnaires were administered to both candidates and applicants from 6 departments in 18 in-person and 12 video interviews. 30 applicant and 87 interviewer survey forms were collected and 
analyzed. T-tests were used to compare the means of the two groups and significance levels were analyzed. Both interviewers and applicants had a higher average global satisfaction for video interviews compared to in person interviews. No difference was indicated in the ability of interviewers to assess the applicants' skills between the two types of interviews. For both interviewers and applicants, video interviews, compared to in person interview, had a lower average score for connecting personally \& establishing rapport and for satisfaction with administrative arrangements. Video interviewed applicants had a $50 \%$ probability of getting accepted in a program compared to $22 \%$ of in person interviewed candidates. We conclude that video interviews appear to be a valuable alternative to in-person interviews, with some sacrifice in personal connection and rapport. Video interviews result in significant time and cost savings for international applicants and have potential implications for the CaRMS process as well.

Sackett KM, Campbell-Heider N, Blyth JB. The evolution and evaluation of videoconferencing technology for graduate nursing education. Comput Inform Nurs. 2004 (Mar-Apr); 22(2):101-6.

Shepherd L, Goldstein D, Whitford H, Thewes B, Brummell V, Hicks M. The utility of videoconferencing to provide innovative delivery of psychological treatment for rural cancer patients: results of a pilot study. J Pain Symptom Manage 2006 (Nov); 32(5):453-61.

Arena J, Dennis N, Devineni T, Maclean R, Meador K. A pilot study of feasibility and efficacy of telemedicinedelivered psychophysiological treatment for vascular headache. Telemed J E Health 2004 (Winter); 10(4):449-54.

\section{Evalutation of an innovative mentorship program - Multilevel mentorship model - Does it meet the needs of residents?}

\section{C.T.J. Elliott, J. Buxton, S. Froese. Department of Health Care and Epidemiology, University of Brit- ish Columbia, Vancouver, BC.}

The UBC community medicine mentorship program was established in 2003 and is continually evaluated. In response to resident feedback, we developed an innovative mentorship model that involves mentorship of junior residents by both mentors from the professional community and senior residents. This new multilevel mentorship model (MMM) was implemented in 2005. It was evaluated for its ability to (1) foster professional and personal relationships among mentors and mentees, (2) help residents develop career goals and (3) support residents who were having challenges in the program.

The program was evaluated using an on-line survey, with both Likert scale and short-answer responses. The survey was completed by 10/13 (77\%) residents, 7/13 (54\%) community medicine professionals (CMPs). For the first level, CMP-resident mentorship, 9/10 residents and 5/7 CMPs agreed that a positive relationship was maintained, and that they benefited from the relationship; 8/10 residents agreed that career counseling occurred. Two of the three residents who had conflict in the program felt that they were supported by their CMP mentor. Mentorship was a positive experience even for two residents who left the program. For the second level, senior-junior resident mentorship, all relationships started within the first month of the program and all residents agreed that a positive relationship was maintained throughout the year. Career counseling occurred in $2 / 3$ junior-senior resident pairs. All three residents agreed that their resident mentor supported them during a conflict. Several resident- and CMP-mentors described heightened awareness of issues that residents face in training.

The multilevel mentorship model has considerable potential for fostering mentoring relationships, career planning, and helping residents overcome the challenges of residency.

Barondess JA. Mentoring in biomedicine. J Lab Clin Med 1197; 129:487-91.

Jackson VA, Palepu A, Szalacha L, Caswell C, Carr PL, Inui T. "Having the right chemistry": a qualitative study of mentoring in academic medicine. Acad Med 2003; 78:328-334.

Williams LL, Levine JB, Malhotra S, Holtzheimer P. The good-enough mentoring relationship. Academic Psychiatry $2004 ; 28: 111-115$. 


\section{3. "I just don't want to kill anybody": The first six months of postgraduate training}

\author{
D. Martin, S. Glover Takahashi. Department of \\ Family and Community Medicine, University of \\ Toronto, Toronto, Ont.
}

This paper describes a qualitative study that used focus groups and individual interviews to explore newly graduated medical students' experience of the first six months of a postgraduate training programme. This study explored the residents' concerns, changes that occurred and the influences the residents attributed to those changes during the first six months, this paper focuses on the residents' experience of responsibility during this initial training period. Residents felt there was a huge leap in responsibility when they made the transition from being a medical student to being a doctor, specifically in the areas of knowledge, practice management, and relationships. This paper describes how the residents felt there was a disconnect between their experience of responsibility as a medical student and their experience of responsibility as a doctor. Residents were concerned they lacked the necessary medical experience and expertise for someone wearing the title "doctor". It was not until residents felt relatively confident that they were not going to harm patients with their knowledge that they were able to begin the process of understanding what it meant to be the family physician, which allowed them to begin identifying with the role of family medicine resident. This process took weeks for some residents and several months for others. This study lays the groundwork for better understanding the transition experience from undergraduate to postgraduate training from the resident's perspective. This paper focuses specifically on the concerns residents had adjusting to their new responsibilities and the implications this might have for medical educators and curriculum developers.

Hirsh DA., Ogur B, Thibault GE, Cox M. "Continuity" as an Organizing Principle for Clinical Education Reform. The New England Journal of Medicine 2007 (Feb):858-866.
Kendall ML, Hesketh EA, Macpherson SG. The learning environment for junior doctor training - what hinders, what helps. Medical Teacher 2005; 25:619 - 24.

Luthy C, Perrier A, Perrin E, Cedrascht C, Allaz AF. Exploring the major difficulties perceived by residents in training: a pilot study. Swiss Medical Weekly 2004; 134:612-17.

\section{Remediation plans: Effectively matching trainee needs to remediation plans}

\section{S. Glover Takahashi, D. Martin, S. Verma, S. Ed- wards. University of Toronto, Toronto, Ont.}

This paper is a retrospective study reporting on the development of remediation plans for residents who are having difficulty meeting the established program goals and objectives. Additionally, the paper describes the implementation of a consistent, competency focused approach to remediation using a standardized needs assessment and intervention planning tool has functioned to better manage difficulty. First, the paper provides a profile of the educational needs of 20 recent cases describing their specialty programs, training levels and the competency areas of difficulty. Next the paper outlines an educational inquiry tool used by residency program directors to develop, implement and evaluate the trainee's remediation programs. The tool includes inquiry questions which the faculty answer in the development of a customized remedial educational plan in the such areas as: trainee background, trainee information, overall rationale for remediation plan, training profile, purpose of remediation, details of remediation plan, anticipated outcome of remediation plan, other factors impacting trainee success. The tool is designed to be reviewed with trainee input to ensure the desired outcomes and process for the remediation plan are transparent for both the trainee and program director. Finally three case studies are described in detail including of the types of problems that lead to remediation, examples of the remediation plans developed and the range of approaches employed to support the success of residents. The paper then summarizes the identified key issues and options in optimizing success for residents in difficulty. 
Christopher I, Doty CI, Lucchesi M. The Value of a Web-based Testing System to Identify Residents Who Need Early Remediation: What Were We Waiting For? Acad Emerg Med 11(3):324.

Beeson MS, Jwayyed S. Development of a Specialtywide Web-based Medical Knowledge Assessment Tool for Resident Education. Acad. Emerg. Med 2004 (Mar); 11(3):324.

Boiselle PM. Remedy for Resident Evaluation and Remediation, Academic Radiology 2005(July); 12(7):894-900.

\section{YOUNG INVESTIGATORS FORUM}

\section{The role of THOA in calcium sensitization in hu- man myometrial smooth muscle}
Hector Aguilar and B.F. (Peter) Mitchell, University of Alberta.

Improved understanding of the regulation of contractions of uterine smooth muscle (myometrium) is essential to develop more successful strategies for prevention of premature birth, which remains the most common cause of infant death and disability. Oxytocin (OT) and prostaglandin (PG) $\mathrm{F}_{2 \mathrm{a}}$ are potent myometrial stimulants which induce an increase in intracellular $\mathrm{Ca}^{++}$. This activates myosin light chain kinase (MLCK) and subsequently the cell's contractile machinery. However, there is poor correlation between the rise in $\mathrm{Ca}^{++}$and the strength of the myometrial contraction. Contractile strength greatly increases at the time of parturition partly due to $\mathrm{Ca}^{++}$-independent factors that sensitize the muscle to the rise in intracellular $\mathrm{Ca}^{++}$In vascular smooth muscle, one key regulator in this process of $\mathrm{Ca}^{++}$sensitization is the monomeric G-protein, RhoA which in turn activates Rho-associated kinase (ROK). Studies in the rat myometrium have shown that RhoA and ROK are involved in enhancing OT-induced contractions. The potential role of the RhoA/ROK system in uterine contractility at the time of parturition has not been investigated in the human myometrium or in human cell lines.

We propose to investigate the role of RhoA/ROK in the human myometrium using molecular cloning techniques. We have constructed expression plasmids for wild type, dominant positive (constitutively active), and dominant negative (constitutively inactive) isoforms of RhoA and synthesized purified proteins using a bacterial (BL21) translation system. These constructs will be introduced into primary and immortalized human myocytes using the protein transduction domain (TAT) derived from the HIV virus, which is capable of introducing whole proteins into mammal- 
ian cells. RhoA activation/translocation to the plasma membrane will be visualized using real time confocal microscopy in experiments where the RhoA proteins have been tagged with green fluorescent protein (GFP). Following introduction of the normal and mutant G-proteins, the downstream targets of activated ROK will be assayed for phosphorylation status using near infrared (NIR) fluorescence imaging of western blots or in-cell westerns. These targets include the myosin binding subunit (MBS) of myosin light chain phosphatase (MLCP), and two peptide phosphatase inhibitors of MLCP, CPI-17 and PHI-1. In addition, we propose to measure ROK activity directly using a direct enzyme assay. We will monitor calcium transients using fluorescence microscopy to verify the calcium independence of our measurements. These experiments will determine the role of the RhoA/ROK system in the mechanisms that may determine human uterine contractility. This information may direct new strategies to prevent or treat preterm labour.

\section{Effects of maternal nutrient restriction on placen- tal morphology and insulin-like growth factor sys- tem expression}

C Albion, S Dixon, K Nygard, C Reid and V Han, Department of Obstetrics and Gynaecology, Paediatrics and Anatomy and Cell Biology, Children's Health Research Institute and Lawson Health Research Institute, The University of Western Ontario, London, Ontario, Canada

Uteroplacental insufficiency is one of the major causes of fetal growth restriction (FGR) in developed countries. The pathophysiology is likely the result of fetal undernutrition due to the impairment of nutrient and substrate transfer from the mother to the fetus. Fetal undernutrition due to maternal undernutrition is not a major cause of FGR in developed countries compared to developing countries. However, FGR can be reproducibly created in experimental animals by maternal undernutrition, and is commonly utilized to study the pathophysiology of fetal undernutrition in the fetus and the placenta. The insulin-like growth factor (IGF) system is the principal growth factor in- volved in regulating normal fetal and placental growth and its aberrant expression is associated with the development of FGR. We hypothesized that placenta undergoes adaptive changes in pregnancies with maternal undernutrition, the effects of which are mediated by the IGF system.

Methods: A mouse model of FGR was generated in CD-1 mice using maternal total caloric nutrient restriction. At 6.5 days of pregnancy, mice were randomly assigned to the control group (ad libitum diet) or global nutrient restriction (GNR) diet group (70\% of predetermined food intake of each gestational day). FGR can be reproducibly induced in the fetuses without effect in litter size. Placentae were collected at 18.5 days and were fixed in $4 \%$ paraformaldehyde. Five $\mathrm{mm}$ tissue sections were prepared by standard techniques and were stained with hematoxylin \& eosin for morphometry, PAS for glycogen staining, and immunohistochemistry against IGF-I and -II, IGFBP$1,-2$ and -3 using specific antisera for cell-specific expression of the IGF system. The morphology of the placentae was analyzed using a computerized image analysis system.

Results: Placentae were significantly smaller in FGR mice compared to controls $(94 \pm 4 \mathrm{mg}$ SEM vs $72 \pm 3 \mathrm{mg}$ SEM). Preliminary results demonstrate changes in FGR mouse placentae tended to be a result of a reduction in spongiotrophoblast layer $(p=0.066$, one-tailed t-test) while the labyrinthine trophoblast layer was maintained. Morphometric analysis of the labyrinth demonstrated an increase in the diameter of both maternal and fetal vessels with a reduction in the thickness of the interchorial layer. The IGF-I and -II, IGFBP-1, IGFBP-2 and IGFBP-3 immunoreactivity were all reduced in FGR placentae compared to the controls.

Conclusion: These findings suggest that maternal nutrient restriction induces changes in the placenta that may potentially lead to improved nutrient and substrate transfer from mother to fetus, in an attempt to maintain fetal viability. However, these compensatory changes are not sufficient to maintain growth. These changes may result from the alteration of expression of the IGF system genes. 


\section{Atomoxetine, but not paroxetine, blocks norepi- nephrine reuptake in depressed patients}

\author{
F. Aldosary, P. Tremblay, C. Hébert, and P. Blier. \\ University of Ottawa Institute of Mental Health \\ Research, Ottawa, ON
}

Purpose: Paroxetine is a potent serotonin (5-HT) reuptake inhibitor. However, a purported norepinephrine (NE) reuptake blockade action remains to be established. Atomoxetine is a potent NE reuptake inhibitor with the indication of attention deficit hyperactivity disorder (ADHD). The present study was aimed at confirming a NE reuptake inhibitory action with ascending doses of atomoxetine and possibly with paroxetine in depressed patients.

Methods: Patients were randomized to escalating doses of either paroxetine (20 to $50 \mathrm{mg} /$ day), or atomoxetine (25-80 mg/day) in a four to six week period. Inhibition of NE reuptake was assessed using the attenuation of systolic blood pressure (SBP) elevations produced by intravenous injections of tyramine. Tyramine penetrates into peripheral $\mathrm{NE}$ terminals via the NE reuptake transporter and releases NE. Then, NE acts on the vascular adrenoceptors, which causes an elevation of SBP. Drugs that block NE reuptake attenuate the pressor effects of tyramine. Two-way ANOVA for repeated measures for doses of tyramine and treatments were used to assess the effects of the different drug regimens on the pressor response to loads of 3-6 mg of tyramine. Sixteen patients with unipolar major depressive disorder were assessed weekly after increasing the dose of paroxetine (9 patients) and atomoxetine (7 patients).

Results: Atomoxetine exerted a robust inhibition of the tyramine response, starting at the dose of $25 \mathrm{mg} /$ day in a dose-dependent pattern. Neither the low nor the high doses of paroxetine altered the tyramine pressor response.

Conclusions: These results provide evidence that atomoxetine started significantly inhibiting NE reuptake at subtherapeutic dose for ADHD, whereas paroxetine leaves the activity of the NE transporter unaltered, even at the highest recommended dose for depression.

\section{Global gene expression analyses in early experi- mental osteoarthritis reveal novel players in articu- lar cartilage degeneration}

Tom Appleton, CIHR Group in Skeletal Development \& Remodeling, Dept. of Physiology \& Pharmacolgy, University of Western Ontario,

Shirine Usmani, Vasek Pitelka, Dept. of Physiology \& Pharmacolgy, University of Western Ontario, Jim Henry, Dept. of Physiology \& Pharmacolgy, University of Western Ontario, Michael G. Degroote Institute for Pain Research \& Care, McMaster University,

Suzanne Bernier, CIHR Group in Skeletal Development \& Remodeling, Dept. of Anatomy \& Cell Biology, University of Western Ontario,

Frank Beier, CIHR Group in Skeletal Development \& Remodeling, Dept. of Physiology \& Pharmacolgy, University of Western Ontario

Introduction: Articular cartilage degeneration is a hallmark of osteoarthritis (OA). We sought to identify dysregulated genes in degenerating cartilage and hypothesized that altered growth factor expression causes cartilage degradation in OA.

Methods: Genome-wide microarray analysis of RNA harvested directly from sham (control) and degenerating articular cartilage was performed using our previously characterized pre-clinical rat model of knee $\mathrm{OA}^{1}$. Known OA genes were validated using RNA samples (real-time PCR) and histological sections (immunofluorescence) from independent animals. Functional studies in chondrocytes and articular cartilage explants investigated the effects of one identified factor (transforming growth factor alpha (TGF- $\alpha$ )) on cartilage degeneration. The effects of TGF- $\alpha$ on primary chondrocyte morphology, proliferation, gene expression, and SOX9 transcription factor expression were assessed.

Results: Dysregulated gene expression profiles in degenerating cartilage included known OA genes ${ }^{2}$. Microarray expression profiles were consistently validated at RNA and protein levels by alternative methods. Several genes previously unstudied in OA cartilage were upregulated, including growth factors (e.g. 
TGF- $\alpha$ and kit ligand), cell surface receptors (e.g. endothelin type A receptor), and proteases (e.g. cathepsin S). Functional studies demonstrated that TGF- $\alpha$ alters chondrocyte morphology through reorganization of the actin cytoskeleton. TGF- $\alpha$ also stimulated primary chondrocyte proliferation and chondrocyte cluster formation in cartilage explants. Chondrocyte expression of anabolic genes and total collagen protein levels were reduced by TGF- $\alpha$, while expression of catabolic factors increased. Finally, TGF- $\alpha$ reduced both the expression of total SOX9 and levels of phosphorylated (active) SOX9.

Conclusions: Our microarray study identified numerous factors previously unstudied in OA cartilage, including increased levels of TGF- $\alpha$. Functional studies determined that TGF- $\alpha$ promotes cartilage degeneration through chondrocyte proliferation and catabolic factor expression. Further, TGF- $\alpha$ inhibits chondrocyte anabolism, likely through a mechanism involving suppression of SOX9.

References:

${ }^{1}$ C.T.G. Appleton et al. (2007). Arthritis Res Ther 9(1):R13. ${ }^{2}$ C.T.G. Appleton et al. (2007), Arthritis Rheum In Press.

\section{Profiling YB-1 responsive genes in basal-like breast cancer cells by ChIP-on-chip reveals direct binding to PIK3CA}

Astanehe A, MD/PhD Program, University of British Columbia, Vancouver, BC, Laboratory for Oncogenomic Research, Departments of Pediatrics, Experimental Medicine and Medical Genetics, University of British Columbia, Vancouver, BC Finkbeiner M, Jiang $H$ and SE Dunn, Laboratory for Oncogenomic Research, Departments of Pediatrics, Experimental Medicine and Medical Genetics, University of British Columbia, Vancouver, BC

Purpose: Basal-like breast cancers (BLBC) are typically very aggressive and they are also prone to a high rate of recurrence. We recently identified the transcription factor Y-box binding protein-1 (YB-1) as an important component of BLBC by screening breast tumour tissue microarrays. YB-1 is well known for its ability to confer chemotherapy resistance and to promote the growth of a wide range of cancer cell types. The breast cancer cell line SUM149 was characterized by us as having all the hallmarks of BLBC including a lack of the estrogen, progesterone, and Her-2 receptors. We also find that they express high levels of the epidermal growth factor receptor, a YB-1 responsive gene.

We performed a genome-wide promoter screen of the possible YB-1 responsive genes using the NimbleGen ChIP-on-chip (COC) platform to begin to understand how this oncogene regulates the growth of basal-like breast cancer cells. YB-1 was found to bind to $\sim 6,700$ human promoters. Several members of the phosphatidylinositol-3-kinase (PI3K) pathway were identified (p110a, p85, Akt-2, ILK). Of particular interest was the identification of PIK3CA, the gene that codes for the p110a catalytic subunit of PI3K. PI3K, a lipid kinase with important roles in neoplasia, phosphorylates membrane inositol lipids resulting in activation of downstream effectors that are involved in cellular responses such as cell proliferation, survival, metabolism, and cytoskeletal reorganization. Many studies have suggested importance of the role of PI3K signaling in various types of cancer. Approximately $20 \%$ of breast cancers harbour somatic activating mutations in $P I K 3 C A$, and about $8 \%$ have amplification of PIK3CA. The remainder of the cancers have elevated levels of PI3K via other mechanisms including increased transcription.

Methods \& Results: Here we propose that YB-1 overexpression in cancer leads to increased PIK3CA transcription via direct binding to the promoter. To extend our COC findings, we knocked down YB-1 with siRNA and observed a concomitant loss in p110a by immunoblotting. We have recently identified two alternate $P I K 3 C A$ transcriptional start sites (exon 1a and $1 \mathrm{~b}$ ) and two alternate $P I K 3 C A$ promoters (promoter $1 \mathrm{a}$ and $1 \mathrm{~b}$ ). We mapped potential YB-1 binding sites on PIK3CA promoters $1 \mathrm{a}$ and $1 \mathrm{~b}$, and identified five putative YB-1 binding sites within promoter 1a and one putative binding site within promoter $1 \mathrm{~b}$. We further performed traditional ChIP and EMSA to confirm the interaction of YB-1 with the putative binding 
sites on PIK3CA promoter, and determined that YB-1 binds to promoter $1 \mathrm{a}$, but not to promoter $1 \mathrm{~b}$.

Conclusion:The demonstration that YB-1 binds directly to the PIK3CA promoter and induces its activity identifies a novel mechanism whereby activation of YB-1 and subsequent up-regulation of PIK3CA may contribute to the pathophysiology, outcomes and therapeutic responsiveness of breast cancer.

A.A. is supported by a Canadian Institutes of Health Research - Children and Family Research Institute -UBC MD/PhD Studentship Award.

\section{The character of anti-HCV $\mathrm{T}$ cell responses differs between spontaneous and treatment-induced viral clearance}

Barrett, L, Immunology Program, Memorial University of Newfoundland, St. John's, NL, Department of Medicine, Dalhousie University, Halifax NS

G Hirsch, Department of Medicine, Dalhousie University, Halifax NS

$M$ Gallant, C Howley, Immunology Program, Memorial University of Newfoundland, St. John's, NL,

K Peltekian, Department of Medicine, Dalhousie University, Halifax NS,

M Grant, Immunology Program, Memorial University of Newfoundland, St. John's, NL

Introduction: Hepatitis C virus (HCV) is a common infection with approximately 170 million individuals infected worldwide. The majority of exposed individuals develop chronic infection, with viral clearance being the exception to the rule. Even with antiviral therapy, only $50-75 \%$ of treated individuals become HCV RNA negative. The role of the adaptive immune response, and particularly T cells, has been well established in other viral infections but its function in HCV infection is unclear, making it difficult to develop either prophylactic or therapeutic vaccine strategies.

Objectives: Compare the breadth, specificity, and magnitude of anti-HCV T cell responses in individuals who are chronically HCV-infected with those who clear HCV spontaneously or after antiviral treatment.
Methods: We assessed $\mathrm{T}$ cell responses in 3 groups of HCV exposed individuals: 18 people who were chronically $\mathrm{HCV}$ infected (anti-HCV antibody and HCV RNA positive), 5 who were exposed to HCV but cleared the virus without treatment (antibody positive, RNA negative), and 17 who responded to anti-HCV treatment (antibody positive but RNA negative after treatment). $\mathrm{CD}^{+} \mathrm{T}$ cell responses to $\mathrm{HCV}$ and recall antigens were measured by standard ${ }^{3} \mathrm{H}-$ thymidine proliferation assay, and $\mathrm{CD}^{+} \mathrm{T}$ cell responses were evaluated by incubating peripheral blood mononuclear cells (PBMC) overnight with 15mer peptides spanning the entire HCV-1a genome. The number of HCV-specific interferon-gamma (IFNg)-producing cells per million PBMC was estimated by ELISPOT.

Results: Anti-HCV CD4+ $\mathrm{T}$ cell responses were uncommon, and of low magnitude in all groups. Responses were only to peptides in the core region. The overall breadth of the anti-HCV $\mathrm{CD}^{+}$response was greatest in treated responders (average 43/44 peptide pools tested positive) and least in those who failed treatment (average 11/44). All clearers had responses to the NS5 region. The magnitude of the $\mathrm{CD}^{+}{ }^{+}$response tended to be highest in the treated responders, but there was no significant difference between groups.

Conclusions: The character of the anti-HCV T cell response differs not just between chronic infection and clearance, but also between spontaneous versus treatment-associated HCV clearance. This suggests that it is likely a combination of T cell breadth, magnitude and specificity that results in viral clearance. Based on these results, development of therapeutic and prophylactic vaccine strategies may need to target different $\mathrm{T}$ cell responses. 
Through the looking-glass: Objectivity, interpretation, and the construction of social kinds as emerging issues in research ethics

Berkhout SG, MD/PhD Program, University of British Columbia, Vancouver, BC, The Centre for Excellence in HIV/AIDS, Vancouver, BC, Department of Philosophy, University of British Columbia, Vancouver, BC,

Tyndall $M W$, The Centre for Excellence in HIV/AIDS, Vancouver, BC,

$S$ Anderson, Department of Philosophy, University of British Columbia, Vancouver, BC

Background: Access to the means of knowledge production is severely limited for many individuals who are socially, politically, and economically disadvantaged. Of particular concern, largely overlooked in bioethics discourse, is the manner by which surveillance, identification, and classification contribute to the creation of particular populations based on harmful social identities, and the subsequent stigmatization of the individuals subject to analysis.

Methods: Drawing from a range of philosophical and sociological literature, including Hans-Georg Gadamer, Charles Taylor, Bruno Latour, and Deborah Lupton, as well as public health discourse, this paper gives an analysis of a challenging metaphysical and ethical problem related to research practices and public health interventions in vulnerable communities. The themes of objectivism and stigmatization are illuminated by focusing on research related to HIV infection among survival sex workers in Vancouver's downtown eastside.

Results: Reductionist models of human behaviour presuppose a clear distinction between description and evaluation, contributing to an understanding of social reality as structured by objective, base level data, and misconstruing modes of social relations as individual action. In the context of HIV risk, an ethical problem emerges: describing individual actions as "data," or "fact," serves to construct and reinforce transgressive social identities. Given that stigmatization is itself part of the context of adverse health outcomes and HIV infection, practices relying on methods that pre- sume representational authority and fail to critically interpret human action are ethically problematic. Resolving difficulties within the methodological underpinnings of public health and HIV behavioural research requires an understanding of many social science methods as hermeneutical, while enabling the contribution of disparate standpoints to the production of scientific knowledge.

Conclusions: The implications of presumed objectivity and representational authority demand a reconsideration of how research in vulnerable communities might be conducted, such that it produces results that are scientifically rigorous and socially responsible.

S.G.B. is supported by a Canadian Institutes of Health Research - Providence Health Care Research Institute - UBC MD/PhD Studentship Award

\section{Rapid electrical pacing of cardiomyocytes alters the behavior of cardiac fibroblasts: Implications for atrial fibrillation}

Brett Burstein, MD/PhD Program, McGill University, Montreal, QC, Department of Pharmacology, McGill University, Montreal, QC, Research Centre, Montreal Heart Institute, Montreal, QC, Xiao-Yan Qi, Research Centre, Montreal Heart Institute, Montreal, QC,

Angelino Calderone, Research Centre, Montreal Heart Institute, Montreal, QC, Department of Physiology, University of Montreal, Montreal, QC, Stanley Nattel, Department of Pharmacology, McGill

University, Montreal, QC, Research Centre, Montreal Heart Institute, Montreal, QC

Background: Atrial fibrillation (AF) produces atrial tachycardia-related changes in atrial electrophysiology, providing a possible explanation for the progressive nature of the arrhythmia. Structural remodeling results from ventricular dysfunction due to a rapid response to AF, but whether AF itself can cause atrial fibrosis remains unclear. This study investigated the hypothesis that rapid atrial cardiomyocyte activation produces factors that influence atrial fibroblast proliferation and secretory functions. 
Methods: Cultured canine atrial fibroblasts were treated with medium from rapidly-paced atrial cardiomyocytes (group 5Hz), non-paced cardiomyocytes (group NP) and cardiomyocyte pacing medium alone (group $\varnothing$ ), and analyzed by $\left[{ }^{3} \mathrm{H}\right]$ thymidine incorporation, Western-blot and real-time RT-PCR.

Results: Rapidly-paced cardiomyocyteconditioned medium had a potent anti-proliferative effect, reducing $\left[{ }^{3} \mathrm{H}\right]$ thymidine uptake compared to non-paced cardiomyocyte-conditioned medium and medium alone $(2,143 \pm 1,490 * *$ vs. $15,870 \pm 3,343$ and $16,440 \pm 4,193$ respectively, $* * P<0.01$ vs. both NP and $\varnothing)$. Conditioned medium from rapidly-paced cardiomyocytes increased $\alpha$ SMA protein reflecting an activated myofibroblast phenotype $(1.62 \pm 0.20 * *$ vs. $1.08 \pm 0.26$ and $1.01 \pm 0.24)$, collagen $-1(2.41 \pm 0.22 *$ vs. $1.49 \pm 0.33$ and $1.10 \pm 0.19, * P<0.05$ both NP and $\varnothing)$ and fibronectin-1 $\left(3.05 \pm 0.28^{*}\right.$ vs. $1.80 \pm 0.45$ and $1.20 \pm 0.19)$ mRNA expression compared to control cells. Treatment of the conditioned medium with the AT1 receptor blocker valsartan, partially attenuated the pacing-induced $\alpha$ SMA increase but had no effect on fibroblast proliferation. Atrial tissue from 1-week atrial-tachypaced dogs with AV block/ventricular pacing to control ventricular rate similarly showed upregulation of collagen-1 $(2.6 \pm 0.5$ vs. $0.7 \pm 0.3$, $P<0.01)$ and fibronectin-1 $\quad(4.9 \pm 0.6$ vs. $1.1 \pm 0.4$, $P<0.001)$ mRNA versus unpaced shams. Conclusion: Rapidly-paced cardiomyocytes release substances that profoundly alter cardiac fibroblast function and induce an activated myofibroblast phenotype that is reflected by altered ECM-gene expression in vivo. These findings are consistent with recent observations that $\mathrm{AF}$ per se causes ECM remodeling and may have important consequences for understanding and preventing the mechanisms underlying AF progression.

(Supported by CIHR)

\section{The role of AMP-activate protein kinase (AMPK) in the regulation of cardiac hypertrophy}

Anita Y. M. Chan, Cardiovascular Research Group, Carrie-Lynn M. Soltys, Cardiovascular Research Group, Department of Pediatrics, , University of Alberta, Edmonton, Alberta

Jason R. B. Dyck. Cardiovascular Research Group, Departments of Pediatrics and Pharmacology, University of Alberta, Edmonton, Alberta.

Backgrond: The polyphenol resveratrol has been attributed to some of the cardioprotective effects of red wine consumption, including the ability to inhibit hypertrophy via its antioxidant properties. A recent discovery in hepatocytes showed that resveratrol can activate AMP-activated protein kinase (AMPK), a key regulator of cellular energy homeostasis. However, it is currently unknown whether resveratrol can also activate cardiac AMPK and the functional consequence of this. As we have shown that activation of AMPK inhibits protein synthesis associated with cardiac hypertrophy, we hypothesized that an additional mechanism by which resveratrol inhibits hypertrophy is via AMPK activation.

Methods: To investigate this, neonatal rat cardiac myocytes were treated with vehicle (Veh) or $50 \mu \mathrm{M}$ resveratrol (Resv) for 24 hours and $10 \mu \mathrm{M}$ phenylephrine (PE) to induce hypertrophy. Contributors of the hypertrophic response, such as protein synthesis and specific intracellular signalling pathways, were measured using $\left[{ }^{3} \mathrm{H}\right]$-phenylalanine incorporation and immunoblot analysis, respectively.

Results: Activation of AMPK was achieved with resveratrol even in the presence of phenylephrine, as shown by increased AMPK phosphorylation (Veh+PE $=0.69 \pm 0.06 v s$ Resv $+\mathrm{PE}=1.57 \pm 0.29$ arbitrary units, $\mathrm{p}<0.01)$. Resveratrol also significantly decreased protein synthesis induced by phenylephrine $(\mathrm{Veh}+\mathrm{PE}=$ $45702.5 \pm 5252.9$ vs Resv+PE $=32929.0 \pm 4512.9$ disintegrations per minute, $\mathrm{p}<0.05)$. This was associated with reduced activities of regulators of protein synthesis, namely p70S6 kinase and eukaryotic elongation factor-2 (eEF2). Specifically, resveratrol countered the effects of phenylephrine by blunting the increase 
in p70S6 kinase phosphorylation while partially restoring eEF2 phosphorylation. Furthermore, resveratrol dramatically decreased nuclear factor of activated T-cells (NFAT) promoter activity, as shown by reduced luciferase activity driven by a NFAT-responsive promoter $($ Veh $+\mathrm{PE}=171100 \pm 7881$ vs Resv $+\mathrm{PE}=$ $27530 \pm 5975$ luciferase activity, $\mathrm{p}<0.001$ ).

Conclusions: As the calcineurin-NFAT pathway is thought to be involved in pathological hypertrophy, this provides further evidence that AMPK activation has therapeutic potential, and shows another mechanism by which resveratrol can prevent hypertrophic growth.

\section{The metalloproteinase ADAM10 is required for retinal ganglion cell axon guidance in the develop- ing visual system}

\section{Y.Y. Chen, C.L. Hehr, K. Atkinson-Leadbeater, J.C. Hocking, S. McFarlane. University of Calgary, Calgary, AB}

Background: The growth cone interprets cues in its environment in order to reach its target. We want to identify molecules that regulate growth cone behaviour in the developing embryo. We investigated the role of $\underline{\mathrm{A}}$ disintegrin and metalloproteinase 10 (ADAM10) in axon guidance in the developing visual system of African frog, Xenopus laevis.

Methods: We first examined the expression patterns of adam10 mRNA by in situ hybridization. We then exposed the developing optic tract to an ADAM10 inhibitor, GI254023X, in vivo. Lastly, we inhibited ADAM10 function in diencephalic neuroepithelial cells (through which retinal ganglion cell (RGC) axons extend) or RGCs by electroporating or transfecting an ADAM10 dominant negative ( $d n$ adam10).

Results: We show that adam10 mRNA is expressed in the dorsal neuroepithelium over the time RGC axons extend towards their target, the optic tectum. Second, pharmacological inhibition of ADAM10 in an in vivo exposed brain preparation causes the failure of RGC axons to recognize their target at low concentrations $(0.5,1 \mu \mathrm{M})$, and the failure of the ax- ons to make a caudal turn in the mid-diencephalon at higher concentration $(5 \mu \mathrm{M})$. Thus, ADAM10 function is required for RGC axon guidance at two key guidance decisions. Finally, molecular inhibition of ADAM10 function by electroporating dn-adam10 in the brain neuroepithelium causes defects in RGC axon target recognition (57\%) and/or defects in caudal turn $(12 \%)$, as seen with the pharmacological inhibitor. In contrast, molecular inhibition of ADAM10 within the RGC axons has no effect. Conclusions: These data argue strongly that ADAM10 acts cell nonautonomously within the neuroepithelium to regulate the guidance of RGC axons. This study shows for the first time that a metalloproteinase acts in a cell nonautonomous fashion to direct vertebrate axon growth. It will provide important insights into candidate molecules that could be used to reform nerve connections if destroyed because of injury or disease.

\section{References}

Hattori M, Osterfield M, Flanagan JG. Regulated cleavage of a contact-mediated axon repellent. Science 2000; 289(5483):1360-5.

Janes PW, Saha N, Barton WA, Kolev MV, WimmerKleikamp SH, Nievergall E, Blobel CP, Himanen JP, Lackmann M, Nikolov DB. Adam meets Eph: an ADAM substrate recognition module acts as a molecular switch for ephrin cleavage in trans. Cell 2005; 123(2):291-304.

Pan D, Rubin GM. Kuzbanian controls proteolytic processing of Notch and mediates lateral inhibition during Drosophila and vertebrate neurogenesis. Cell 1997; 90(2):271-80.

\section{In vitro validation of a 3-dimensional transrectal ultrasound system for prostate biopsies}

Derek Cool, Dept. of Medical Biophysics, Robarts

Research Institute, London, Ontario,

Shi Sherebrin, Robarts Research Institute, London,

Ontario,

Jonathan Izawa, Joseph Chin, Dept. of Surgery, Division of Urology, University of Western Ontario, Aaron Fenster, Dept. of Medical Biophysics, Robarts

Research Institute, London, Ontario

Introduction: Transrectal ultrasound (TRUS) prostate biopsy $(\mathrm{Bx})$ is currently confined to $2 \mathrm{D}$ information to 
both target and record 3D $\mathrm{Bx}$ locations. Accurate placement of $\mathrm{Bx}$ needles cannot be verified without $3 \mathrm{D}$ information, and recording $\mathrm{Bx}$ sites in 2D does not provide sufficient information to accurately guide the high incidence of repeat $\mathrm{Bx}$. We have designed a 3D TRUS prostate Bx system that augments the current 2D TRUS system and provides tools for biopsyplanning, needle guidance, and recording of the biopsy core locations entirely in 3D.

Methods: Our Bx system displays a 3D model of the patient's prostate, which is generated intraprocedure from a collection of 2D TRUS images, representative of the particular prostate shape. Bx targets are selected, needle guidance is facilitated, and 3D Bx sites are recorded within the 3D context of the prostate model. The complete 3D Bx system was validated, in vitro, by performing standard ten-core $\mathrm{Bx}$ on anatomical phantoms of two patient's prostates. The accuracy of the needle-guidance, Bx location recording, and 3D model volume and surface topology were validated against a $\mathrm{CT}$ gold standard.

Results: The Bx system successfully reconstructed the 3D patient prostate models with a mean volume error of $3.2 \pm 7.6 \%$. Using the $3 \mathrm{D}$ system, needles were accurately guided to the pre-determined targets with a mean error of $2.26 \pm 1.03 \mathrm{~mm}$ and the $3 \mathrm{D}$ locations of the $\mathrm{Bx}$ cores were accurately recorded with a mean distance error of $1.47 \pm 0.79 \mathrm{~mm}$.

Conclusion: We have successfully developed a 3D TRUS prostate biopsy system and validated the system in vitro. A pilot study has been initiated to apply the system clinically.

\section{Molecular characterization of the development of the K65R and M184V drug resistance mutations in Subtype C HIV-1}

Dimitrios Coutsinos, MD-PhD Program, McGill University, Montreal QC, McGill University AIDS Center, Montreal QC, and the Departments of Microbiology \& Immunology, and Medicine, McGill University, Montreal QC,
Cédric F. Invernizzi, McGill University AIDS Center, Montreal QC, Department of Medicine, McGill University, Montreal QC, Daniela Moisi, Maureen Oliveira, McGill University AIDS Center, Montreal QC,

Bluma G. Brenner, Mark A. Wainberg2,3,4, McGill University AIDS Center, Montreal QC, Departments of Microbiology \& Immunology, and Medicine, McGill University, Montreal QC

Background: We have shown that the K65R mutation is selected more rapidly in subtype $C$ than in subtype B HIV-1 isolates in both cell culture and clinical studies. Biochemical comparisons between subtype B and C-derived reverse transcriptase (RT) enzymes revealed similar molecular characteristics that do not explain the more rapid selection of K65R with subtype $\mathrm{C}$ viruses. This study attempts to establish the mechanistic basis for the difference.

Methods: Recombinant subtype C and B HIV-1 RT enzymes were expressed and purified in E. coli. Gel-based nucleotide extension assays were used to study DNA synthesis from various natural and synthetic DNA and RNA templates that spanned regions of the pol gene responsible for the K65R and M184V mutations. Cell based experiments were performed using MT2 cells infected with mutated subtype B HIV-1 pNL4-3 viruses.

Results: The propensity for the more rapid selection of K65R with subtype C enzymes is due to the mechanism of DNA synthesis from a subtype $C$ template. The use of templates containing the 64,65 and 66 codons of the pol gene led to different patterns of DNA synthesis. When subtype C RT was employed to synthesize DNA from subtype $\mathrm{C}$ templates, preferential pausing was seen at the nucleotide position responsible for the AAG to AGG mutation on codon 65 which gives rise to K65R. In contrast, the use of subtype B RT together with a subtype B template reveals a different pattern of DNA synthesis. When subtype B RT was employed with a subtype C template, DNA synthesis stopped at the exact nucleotide position responsible for K65R. This phenomenon was not observed when subtype C RT was used with a subtype B template. A similar method was employed to investi- 
gate if differences exist in the appearance of M184V between subtypes. The results suggest that M184V is not favoured due to its coding sequence and that the propensity for the development of $\mathrm{M} 184 \mathrm{~V}$ remains the same in subtype B and C HIV. In cell culture, K65R was detected faster in subtype B that has been mutated to include the 64/65 codons of subtype $\mathrm{C}$, when compared to wild-type subtype B HIV.

Conclusions: The more rapid emergence of K65R but not M184V in subtype C RT appears to be based on the pol gene coding sequence. These results urge for the analysis of resistance mechanisms to be studied in all HIV subtypes separately and have clinical relevance in regard to the management of subtype $\mathrm{C}$ infections.

\section{Elucidating the role of P63 during development of the mammalian nervous system}

Sagar Dugani, Annie Paquin, David R. Kaplan, and Freda D. Miller. Institute of Medical Science, University of Toronto, Developmental Biology, The Hospital for Sick Children.

Background: The protein p63, a recently discovered member of the p53 family of proteins, is implicated in the maintenance and differentiation of stem cells in the epidermis and is involved in the regulation of naturally-occurring cell death in sympathetic neurons of the peripheral nervous system. Since initial data from our laboratory indicated that p63 is also widely expressed in stem cells and neurons within the developing brain, we assessed its involvement in regulating the genesis and survival of developing cortical neurons. As neurogenesis is initiated at embryonic day 12 (E12), we isolated cortical precursors from $\mathrm{p} 63^{-/-} \mathrm{em}-$ bryos at E14 and cultured them for 2 days in vitro (DIV).

Methods: Based on immunocytochemistry to known markers of apoptosis and neurons, we assessed the level of cell death and neurogenesis.

Results: Compared to $\mathrm{p} 63^{+/+}$cortical precursors, p63-- precursors from littermates showed a $50 \%$ reduction in neuronal death, as assessed by the apoptosis marker, cleaved caspase 3 . Interestingly, the pro- portion of neurons and astrocyte precursors, the latter identified by $\mathrm{S} 100 \mathrm{~b}$ was also reduced in $\mathrm{p} 63^{-/-} \mathrm{em}-$ bryos, as compared to $\mathrm{p} 63^{+/+}$littermates.

Conclusions: These results suggest that p63 may be involved in the regulation of cell survival and in the differentiation of precursors into neurons and astrocytes. To assess the former, we overexpressed TAp63a, a full-length isoform of p63, in E12/13 cortical precursors and assessed the level of cell death after 2 DIV. Compared to control cells, cells transfected with TAp63a demonstrated a 2-fold increase in cell death. Ongoing work will characterize p63 involvement in differentiation of precursor cells into neurons and astrocytes. To assess if these findings are relevant in vivo, we will use $\mathrm{p} 63^{\text {flox,flox }} \mathrm{X}$ Nextin-Cre mice, which have p63 specifically ablated in neural precursors. We will analyze the survival, proliferation, and fate of these p63-/- cells. Together, these studies will help to determine a role for p63 in neural proliferation and apoptosis, processes central to development and response to injury.

\section{A JNK-dependent switch determines the oncogenic or tumor suppressor activity of ILK}

Durbin $A D^{*}$, The Department of Medical Biophysics, $\mathrm{MD} / \mathrm{PhD}$ Department, University of Toronto, Toronto, ON. Division of Hematology/OncologyDepartments of Pediatrics, The Hospital for Sick Children, Toronto, ON,

Somers GR, Department of Laboratory Medicine and Pathobiology, University of Toronto, Toronto, ON, Pediatric Laboratory Medicine5, The Hospital for Sick Children, Toronto, ON,

Forrester M, Division of Hematology/Oncology-

Departments of Pediatrics, The Hospital for Sick Children, Toronto, ON

Hannigan GE, Department of Laboratory Medicine and Pathobiology, University of Toronto, Toronto, ON,

Malkin D. The Department of Medical Biophysics, University of Toronto, Toronto, ON. Division of Hematology/Oncology-Departments of Pediatrics, The Hospital for Sick Children, Toronto, ON 
Background: Integrin-linked kinase (ILK) is a potent intracellular kinase involved in the regulation of multiple proliferation and survival kinases, including protein kinase $\mathrm{B} / \mathrm{Akt}$, glycogen synthase kinase-3 $\beta$ (GSK3 $\beta$ ) and extracellular signal-regulated kinases 1 and 2 (ERK1/2). Evidence suggests ILK is overexpressed and acts oncogenically in a wide variety of primary tumors and genetic models, resulting in induction of tumor cell proliferation, migration, adhesion and angiogenic behaviours. Rhabdomyosarcoma (RMS) is the most common soft-tissue sarcoma of childhood. Histological subclassification of RMS yields two major variants, embryonal (ERMS) and alveolar (ARMS). ERMS, as well as multiple other tumors including breast and lung carcinoma, are commonly associated with loss of heterozygosity at 11p15.5, a region harboring the ILK locus.

Methods: We utilized cell culture and primary tumors to examine the expression and function of ILK.

Results: We demonstrate differential expression of ILK between ERMS and ARMS tumors in vitro and in vivo. RNAi to ILK induces potent gene silencing, with decreases in the phosphorylation of multiple ILK targets. ILK silencing induced inhibition of ARMS, and a contrasting potent stimulation of ERMS cell growth in survival and proliferation assays. These effects were reversed by adenoviral overexpression of ILK in multiple RMS and other tumor cell lines. Moreover, ILK silencing has multiple signaling effects, including induction of cell cycle progression through bmi-land p16 ${ }^{I N K 4 a}$ in ERMS with repression in ARMS, and phosphorylation of c-Jun $\mathrm{NH}_{2}$ terminal kinase (JNK) and c-Jun in ERMS and repression in ARMS cells. Coupling of JNK inhibition with ILK knockdown in ERMS cells inverted the ILK knockdown phenotype, resulting in a significant loss of cell proliferation.

Conclusions: Together, these data confirm the oncogenic role of ILK in alveolar rhabdomyosarcoma, and suggest a novel tumor-suppressive role for ILK signaling in embryonal rhabdomyosarcoma, mediated through the novel ILK target axis, JNK-c-Jun.

\section{Abnormal neurogensis in the hippocampus of a mouse model of fragile $X$ syndrome}

Eadie B, MD/PhD Program, University of British Columbia, Vancouver, BC, Neuroscience Graduate Program, University of British Columbia, Vancouver, BC,

B Christie, Neuroscience Graduate Program, University of British Columbia, Vancouver, BC

Fragile $\mathrm{X}$ syndrome is the most common inherited form of mental retardation. It is a neurodevelopmental disorder that is similar in clinical presentation to autism spectrum disorder. However, unlike autism, Fragile $\mathrm{X}$ syndrome is caused by the silencing of a single gene, and in recent years, a mouse model of Fragile X syndrome has been generated by deletion of the Fmrl gene. Surprisingly, a clear neurobiological basis for the learning impairment observed in both these knockout mice and patients has been difficult to elucidate. We hypothesized that neurogenesis, a process that continues into adulthood in the hippocampus, may be abnormal in this syndrome. Support for such a hypothesis comes from the findings that these new neurons may disproportionately contribute to synaptic plasticity in networks engaged during learning and memory. We have shown that the survival of new cells in the hippocampus of young Fmrl knockout mice is significantly decreased in the ventral hippocampus, a sub-region which may be more involved with emotional, rather than, spatial memory. Further experiments are being conducted to assess the differentiation of these new cells into neurons and glia. We are also characterizing the normal expression of the Fmrl gene product, FMRP, across the phases of neurogenesis in control mice. In conclusion, we have discovered a clear impairment in a process that may be critical to emotionally-significant learning and memory in a mouse model of Fragile X syndrome.

B.E. is supported by a Canadian Institutes of Health Research - Vancouver Coastal Health Research Institute - UBC MD/PhD Studentship Award. 
Innate inflammatory and phagocytic responses to Plasmodium falciparum: linked processes or molecularly discrete pathways?

Laura Erdman, Gabriela Cosio, Samir N. Patel, Sergio Grinstein, Kevin C. Kain, McLaughlin-Rotman Centre for Global Health, University of Toronto, Toronto, Canada

Background: Effective innate immune responses are important for control of malaria blood-stage infection and in preventing progression to severe malaria in non-immune individuals. Key innate defenses include a tightly regulated inflammatory response and host clearance of parasitized erythrocytes (PE). Pattern recognition receptors on macrophages mediate these processes: parasite glycosylphosphatidylinositol (GPI) activates TLR2 to induce inflammation - an excess of which is associated with severe malaria - while scavenger receptor CD36 mediates non-opsonic uptake of PEs. Both pathways are potential therapeutic targets, but it is unclear whether they are interdependent. Findings in other systems implicate CD36 in inflammation and TLR2 in phagocytosis, and recent evidence indicates that CD36 and TLR2 can directly cooperate.

Methods: We investigated whether the innate inflammatory and phagocytic responses of macrophages to P. falciparum are separable: does CD36mediated PE internalization have inflammatory outcomes, and does TLR2 regulate PE uptake? CD36mediated endocytosis failed to induce $\mathrm{TNF} \alpha$ production. As a more representative model of innate PE uptake, $\alpha$-CD36 EBABs (Erythrocyte-Biotin-AvidinBiotinylated antibody) were generated; macrophages internalized EBABs in a CD36-specific manner via a signaling pathway similar to that of PE uptake.

Results: Compared to controls, neither PE nor EBAB internalization induced TNF $\alpha$ release, indicating that the inflammatory consequences of CD36 engagement are ligand dependent. Regarding TLR2 regulation of PE uptake, wild type and $T l r 2^{-\%}$ macrophages showed no differences in EBAB or PE uptake. Pre-treatment of macrophages with P. falciparum GPI enhanced EBAB internalization, but this effect was
CD36-independent and generalizable to other TLR ligands.

Conclusions: These results suggest that innate inflammatory and phagocytic responses of macrophages to malaria are discrete. Thus, therapeutic augmentation of CD36-mediated PE uptake should not exacerbate inflammation, nor should inhibition of the TLR2 pathway compromise CD36-mediated PE clearance. The role of TLR-enhanced internalization in malaria will be further examined.

\section{Targeted deletion of discoidin domain receptor 1 (Ddrl) decreases atherosclerosis, reduces inflam- mation and accelerates matrix accumulation in LDL receptor deficient mice}

Christopher Franco, Guangpei Hou, Wolfgang Vogel, Michelle Bendeck. Department of Laboratory Medicine \& Pathobiology, Faculty of Medicine, University of Toronto, Toronto.

Background: Collagens are abundant within the atherosclerotic plaque where they contribute to lesion volume, mechanical stability, and influence cellular behaviour. The discoidin domain receptor 1 (DDR1), a receptor tyrosine kinase that binds multiple collagen subtypes, has been observed in atheromata of nonhuman primates, but its function during atherogenesis is unclear.

Methods: To examine the role of DDR1 during atherosclerotic plaque development, we generated $D d r I^{+/+} ; L_{d l r^{--}}$and $D d r^{I^{-/} ;} ; d l r^{-/-}$mice and fed them an atherogenic diet for 12 or 24 weeks.

Results: Targeted deletion of $D d r l$ resulted in a 50-60\% reduction in atherosclerotic lesion area in the descending aorta at both 12 and 24 weeks. Atherosclerotic plaques from $\mathrm{Ddr} \mathrm{I}^{-1-} ; \mathrm{Ldlr}^{-/}$mice demonstrated a $49 \%$ decrease in the area occupied by macrophages at 12 weeks, however, plaque SMC content was unchanged. We also observed accelerated deposition of fibrillar collagen and elastin in $D d r 1^{-/} ; L_{d l} r^{-/}$plaques with a $36 \%$ and $45 \%$ increase at 12 weeks, respectively. $D d r 1^{-1 /} ; L d l r^{-/}$mice also demonstrated an early reduction in situ gelatinolytic activity in lesions and gelatin zymography revealed reduced MMP-2 activity 
at 12 weeks. Finally, mRNA expression analysis of laser microdissected plaques demonstrated enhanced expression of type I collagen and elastin, and reduced collagenase expression at 12 weeks. Moreover, mRNA expression of both MCP-1 and VCAM-1 was reduced in $D d r 1^{-/-} ; L d l r^{-/-}$plaques suggesting a novel role for DDR1 in the regulation of vascular inflammation.

Conclusion: Our data support a role for DDR1 as a positive regulator of atherosclerosis; capable of influencing both inflammation and matrix turnover early in plaque development, and when inhibited can result in a persistent reduction in atherosclerosis.

\section{A screen for suppressors of apoptosis identifies a novel gain of function mutation in drosphilia RAS1}

Gafuik C., Agapite J. and Steller H. Howard Hughes Medical Institute, Strang Laboratory of Apoptosis and Cancer Research, The Rockefeller University, 1230 York Avenue, New York, NY 10021, USA

Background: Apoptosis is a morphologically distinct, genetically programmed form of cell death that is evolutionarily highly conserved amongst multi-cellular eukaryotes. Correct regulation of apoptosis is critical for normal development and the prevention of diseases, such as cancer. Genetic analysis of invertebrate model organisms has proven invaluable for the identification and study of key molecules involved in apoptosis. In Drosophila, the proteins Reaper (Rpr), Head involution defective (Hid) and Grim induce cell death in a caspase dependent manner by inhibiting the antiapoptotic function of diapl.

Methods: To further elucidate the molecular mechanisms underlying the control of apoptosis, we conducted a dominant modifier screen for genes that could suppress the strong eye ablation phenotype caused by expressing hid under the control of an eyespecific promoter.

Results: As previously reported, we identified several loss of function mutants in components of the EGFR/Ras/MAPK pathway that could dominantly suppress hid-induced apoptosis. These mutants proved to be alleles of either sprouty or gapl, two negative regulators of the RTK/Ras1 signaling. Here we report the identification and characterization of the first gain of function mutation in the Drosophila RAS1 gene.

Conclusions: Taken together, these findings provide a molecular paradigm for the anti-apoptotic function of ras oncogenes.

\section{Golgi-bound Rab34 is a novel member of the secre- tory pathway}

Neil M. Goldenberg, Institute of Medical Science and

Department of Medicine, University of Toronto, Toronto, Ontario, Canada,

Sergio Grinstein, Department of Medicine, University

of Toronto, Toronto, Ontario, Canada,

Mel Silverman, Program in Cell Biology, Hospital for

Sick Children, Toronto, Ontario, Canada

Background: Golgi-localized Rab34 has been implicated in repositioning of lysosomes and activation of macropinocytosis.

Methods: Using HeLa cells we undertook a detailed investigation of Rab34 involvement in intracellular vesicle transport.

Results: Immunoelectron microscopy and immunocytochemistry confirmed that Rab34 is localized to the Golgi stack and that active Rab34 shifts lysosomes to the cell centre. Contrary to a previous report, we found that Rab34 is not concentrated at membrane ruffles and is not involved in macropinocytosis. Also, Rab34 induced repositioning of lysosomes does not affect transport of the mannose 6-phosphate receptor to endosomes. Most strikingly, HeLa cells depleted of Rab34 by transfection with dominant-negative Rab34, or following RNA interference, failed to transport the temperature-sensitive Vesicular Stomatitis Virus Gprotein fused to GFP (VSVG-GFP) from the Golgi to the plasma membrane. Transfection with mouse Rab34 rescued this defect. Using endogenous MHC class I (MHC) as a marker, an endoglycosidase $\mathrm{H}$ resistance assay showed that ER to medial Golgi traffic remains intact in knock-down cells indicating that Rab34 specifically functions in post-Golgi transport. 
Further, brefeldin A treatment revealed that Rab34 acts at the Golgi, not the trans-Golgi network.

Conclusion: Collectively, these results define Rab34 as a novel member of the secretory pathway acting at the Golgi.

\section{Relative value of plasma nitrotyrosine for predict- ing mortality in patients with coronary artery disease}

Heslop $C L, \mathrm{MD} / \mathrm{PhD}$ Program, University of British Columbia, Department of Pathology and Laboratory Medicine, St. Paul's Hospital, Vancouver, BC

Frohlich JJ, JS Hill, Department of Pathology and Laboratory Medicine, St. Paul's Hospital, Vancouver, BC

Background: Reactive oxygen species (ROS) mediate the signalling of chief inflammatory pathways throughout all stages of atherosclerosis from endothelial dysfunction to plaque rupture. Activated leukocytes within the atherosclerotic lesion produce ROS, causing local and systemic oxidative injury; however, contributions of ROS production to the clinical features atherosclerosis have not yet been clearly established. Markers of oxidative stress include nitrotyrosine (N-tyr), a post-translational modification generated by reactive nitrogen species. N-tyr is enriched in atherosclerotic lesions, where it activates interstitial metalloproteases, which destabilize the lesion and induce plaque rupture. Recent findings associate circulating N-tyr levels with CAD pathogenesis: N-tyr levels are elevated in patients with established CAD, increased by risk factors associated with atherosclerosis, and reduced by statin therapy. The value circulating $\mathrm{N}$-tyr may have for predicting outcome in CAD patients has not yet been determined.

Study Design: We tested the hypothesis that elevated N-tyr predicts mortality in patients with coronary artery disease. Plasma levels of N-tyr were measured using an enzyme-linked immunoassay (Hycult) in a cohort of 619 patients with angiographic evidence of coronary artery disease. After a mean follow-up time of 8.5 years, cases of all-cause mortality (145 cases) and cardiovascular mortality (76 cases) were collected using BC Vital Statistics Agency. The relative value of plasma $\mathrm{N}$-tyr for prediction of mortality was determined using Cox proportional hazards model with adjustment for the following covariates: age, sex, smoking status, hypertension, BMI, LDLcholesterol, total:HDL-cholesterol, plasma c-reactive protein, personal or known family history of CAD, and reported use of lipid-lowering or antioxidant therapies.

Interpretation: Patients whose plasma N-tyr levels were above the cohort median $(71.75 \mathrm{nmol} / \mathrm{L})$ had an increased risk of mortality, however this increased risk did not reach conventional statistical significance after covariate adjustment [HR(CI):1.39(0.96-2.01) $\mathrm{p}=0.07]$. No significant association was observed between N-tyr levels and risk of cardiovascular mortality. While this investigation did not reveal a strong association between elevated $\mathrm{N}$-tyr levels and cardiovascular mortality, the trend for increased risk of all-cause mortality indicates that this marker of oxidative stress could be used to identify patients for whom oxidative processes contribute significantly to disease pathogenesis. Further studies are warranted to establish the clinical value of N-tyr and other oxidative stress biomarkers, with the ultimate goal of improving patient risk assessment, and monitoring primary and secondary cardiovascular risk-reduction strategies.

\section{High affinity IL-2 receptor (CD25) expression among Chronic Lymphocytic leukemia (CLL) patients is independent of mutational status and ZAP-70 positivity}

\author{
Howell, JM; Luider, J; Wong, H; Perrizolo, M; De- \\ metrick, D; Auer, I; Mansoor, A. Department of Pa- \\ thology and Laboratory Medicine, University of \\ Calgary / Calgary Laboratory Services (CLS), Cal- \\ gary Alberta Canada.
}

Background: Recent studies have suggested promising roles for immunotherapy through CD40 ligand /IL-2 signaling pathway in CLL patients. Differential expression of the IL-2 receptor (IL-2 R) has been reported in CLL and other B-cell malignancies. Be- 
cause CLL is divided into two distinct prognostic groups (based on the level of somatic hypermutation or alternatively on the presence or absence of ZAP70), it is important to determine the correlation of IL-2 $\mathrm{R}$ expression with mutational status and/or ZAP-70 positivity in CLL for better patient group stratification in clinical trials.

Methods: In this study, 132 pts (82 M/50F; M: F 1.6) with an age range of 33-91 yrs (median 66 yrs) were included. Of these, $67 / 132(51 \%)$ were found to be $\mathrm{CD}^{+} 5^{+}, 44 / 132$ (33\%) CD25- and $16 \%$ were CD25 dim (not further analyzed). In terms of ZAP positivity, 19/132 (14\%) pts were ZAP-70+ and $113(86 \%)$ were ZAP-70-

Results: Mutational data $(n=93)$ revealed 60/93 (65\%) patients with SHM and 33/ 93 (35\%) without. Correlation between ZAP-70+ and absence of SHM was highly significant $(\mathrm{p}<0.0001)$, however, no statistically significant correlation was noted between CD25 expression and SHM $(p=0.331)$ or ZAP positivity $(\mathrm{p}=0.785)$.

Conclusions: This data suggests that IL-2 R expression, although noted among a significant proportion of patients with B-CLL, is independent of somatic hypermutation or ZAP-70 expression. This observation will be important in evaluation of clinical efficacy of immunotherapy among CLL patients, and points to the existence of another mechanism for the presence of IL-2 $\mathrm{R}$ in these patients.

Abbreviations: B-CLL (B-cell Chronic Lymphocytic Leukemia), SHM (Somatic Hypermutation)

\section{Differential expression of type I interferon genes in plasmacytoid dendritic cells from HIV-infected patients}

Martin D. Hyrcza, Sandy S. Der, Mario Ostrowski, University of Toronto, Department of Laboratory

Medicine and Pathobiology, MD/PhD Program

Background: Plasmacytoid dendritic cells (pDCs) are the most potent producers of type I interferons (IFN). Human genome contains thirteen IFN alpha genes and one IFN beta gene. Research in mice suggests that dif- ferent IFNs are induced by different stimuli, but whether this is true in human cells is unknown. Patients with HIV-1 infection show chronic interferon response in peripheral $\mathrm{T}$ cells, which caused us to analyze the induction of the IFN alpha genes in their dendritic cells.

Methods: Uninfected, acutely infected and longterm non-progressive donors were leukopheresed, following which pDCs were isolated by negative depletion. The dendritic cells were then treated for with one of the following: influenza virus, sendai virus, HIV virus, CpG DNA, imiquimod, or media alone, and the cells' RNA was analysed by real time qPCR for changes in the RNA levels of four IFN alpha genes: $\alpha 1, \alpha 2, \alpha 7, \alpha 8$, as well as IFN beta.

Results: Final results were not available at the time of abstract deposition.

\section{Spatial localization of unknown proteins in the en- doplasmic reticulum predicts function}

Michael D. Jain, Department of Anatomy and Cell Biology, McGill University, Montreal, QC, MDPhD program, McGill University

Hisao Nagaya, Annalyn Gilchrist, Department of Anatomy and Cell Biology, McGill University, Montreal, QC

Miroslaw Cygler, Biotechnology Research Institute,

National Research Council of Canada, Montreal, QC

John J.M. Bergeron, Department of Anatomy and Cell Biology, McGill University, Montreal, QC

Protein synthesis, folding and degradation functions are spatially segregated in the endoplasmic reticulum (ER) with respect to the membrane and the ribosome (rough and smooth ER). Interrogation of a proteomics resource characterizing rough and smooth ER membranes subfractionated into cytosolic, membrane, and soluble fractions gives a spatial map of known proteins involved in ER function. The spatial localization of 224 identified unknown proteins in the ER is predicted to give insight into their function. Here we provide evidence that the proteomics resource accurately predicts the function of new proteins involved in pro- 
tein synthesis (nudilin), protein translocation across the ER membrane (nicalin), co-translational protein folding (stexin), and distal protein folding in the lumen of the ER (erlin-1, TMX2). Proteomics provides the spatial localization of proteins and can be used to accurately predict protein function.

\section{Modulation of NMDA receptors by prion protein}

Houman Khosravani, Yunfeng Zhang, Shigeki Tsutsui, Shahid Hameed, Jawed Hamid, Christophe Altier, Frank R. Jirik, Gerald W. Zamponi. Hotchkiss Brain Institute, University of Calgary, Canada

Background: The precise physiological function of endogenous cellular prion protein (PrPC) remains unclear. It has been shown that PrP-null mice exhibit reduced LTP and greater susceptability to seizure mortality in several in vivo (e.g. kainic acid) models of epilepsy. In addition, PrP-null mice exhibit greater exctitotoxic cell death in response to kainic acid exposure. Methods: In our study we investigated the synaptic properties of WT and PrP-null mice.

Results: Recordings in the CA1 layer of adult hippocampal slices showed that PrP-null mice exhibit a reduced threshold to evoked responses and no difference in paired-pulse facilitation relative to WT animals. In addition, greater excitability was observed in PrP-null slices in response to zero- $\mathrm{Mg} 2+$ induced seizure-like events. Recordings from mature hippocampal cultures showed slightly altered AMPA and GABAA miniature synaptic currents. NMDA mEPSCs were observed to be increased in amplitude and significantly prolonged in decay time. NMDAevokved currents also exhibited markedly prolonged deactivation kinetics. This effect on evoked NMDA currents was reproduced in WT neurons by PrP-RNAi transfection, and eliminated by PrPC transfection into PrP-null neurons.

Conclusions: These data suggest enhanced NMDA activity in PrP-null neurons. Consistent with this finding, in vitro and in vivo excitotoxicity assays demonstrated increased neuronal cell death in PrP-null cultures and animals upon transient exposure to NMDA. The prolonged deactivation kinetics were most consis- tent with functional activity/augmentation of NR2D NMDA receptor subunits, and PrP coimmunoprecipiated with NR2D NMDA receptor subunits. This enhanced NMDA receptor function was paralleleld by increased excitotoxicy in Prp-null mice. Our findings demonstrate a novel functional role for PrP as a modulator of synaptic NMDA currents and attributes a neuroprotective function to $\mathrm{PrP}$.

\section{Genetic characterization of two autosomal reces- sive disorders, Majewski-like and cerebral atrophy syndrome}

Lahiry P, Robinson JF, Vascular Biology Research Group, Robarts Research Institute, London, Ontario,

Siu V, Department of Pediatrics, University of Western Ontario, London, Ontario, Puffenberger EG, Strauss KA, Clinic for Special Children, Strasburg, Pennsylvania,

Hegele RA, Vascular Biology Research Group, Robarts Research Institute, London, Ontario, Rupar CA, Child Health Research Institute, University of Western Ontario, London, Ontario

Introduction: We recently identified two lethal recessive disorders segregating within the same Old Order Amish pedigree. The first disorder, Majewski-like syndrome (MLS), has features that overlap with both Majewski short rib-polydactyly syndrome and hydrolethalus syndrome. MLS is a lethal multi-system disorder that affects the development of the brain, adrenal glands, pituitary gland and bone. The second disorder, cerebral atrophy syndrome (CAS), is characterized by progressive and global loss of brain tissue. Affected children present early in life with microcephaly, seizures, and psychomotor retardation, and possess distinctive MRI findings.

The objective of this study was to identify the genetic bases of these disorders to provide prompt and reliable diagnosis for families.

Methods: Assuming recessive inheritance and mutation homogeneity (autozygosity), we used Affymetrix 10,000-single nucleotide polymorphism (10KSNP) to genotype all affected individuals and identify 
candidate regions. SNP data were analyzed using Agilent GT autozygosity mapping software. LOD scores were used to identify candidate regions, and genes within these regions were prioritized for sequencing.

Results and Conclusion: Because the Ontario Anabaptist population is relatively small, genetically isolated, and historically young, we were able to robustly map candidate regions using relatively low marker density and only a few affected individuals. Our preliminary data is consistent with the clinical observation that MLS and CAS segregate independently, as recessive conditions, within the pedigree. Thus far, we have sequenced 12 genes within the MLS locus, all of which were normal. For CAS, autozygosity mapping yielded two loci with comparable linkage scores, one of which contained no observable mutations. Once the causative mutations have been identified for MLS and CAS, we intend to study their population frequencies and also to pursue in vitro studies of gene and protein functions.

\section{A genome-wide linkage scan for familial partial lipodystrophy susceptibility genes in a German kindred}

M. Lanktree, J. Robinson, J. Creider, H. Cao, D. Carter, D. Horsch, R. Hegele. Robarts Research Institute, Schulich School of Medicine and Dentistry, University of Western Ontario, London, Ont., Philipps-University, Marburg, Germany

Background: In Dunnigan-type familial partial lipodystrophy (FPLD) patients are born with normal fat distribution, but subcutaneous fat from extremities and gluteal regions are lost during puberty. The abnormal fat distribution leads to the development of metabolic syndrome (MetS), a cluster of phenotypes including hyperglycemia, dyslipidemia, hypertension, and visceral obesity. The study of FPLD as a monogenic model of MetS may uncover genetic risk factors of the common MetS which affects $~ 30 \%$ of adult North Americans. Two molecular forms of FPLD have been identified including FPLD2, resulting from heterozygous mutations in the LMNA gene, and FPLD3, resulting from both heterozygous dominant negative and haploinsufficiency mutations in the PPARG gene. However, many patients with clinically diagnosed FPLD have no mutation in either LMNA or PPARG, suggesting the involvement of additional genes in FPLD etiology.

Methods: Here, we report the results of an Affymetrix $10 \mathrm{~K}$ GeneChip microarray genome-wide linkage analysis study of a German kindred displaying the FPLD phenotype and no known lipodystrophycausing mutations.

Results: The investigation identified three chromosomal loci, namely 1q, 3p, and 9q, with nonparametric logarithm of odds (NPL) scores $>2.7$. While not meeting the criteria for genome-wide significance, it is interesting to note that the $1 \mathrm{q}$ and $3 p$ peaks contain the LMNA and PPARG genes respectively.

Conclusions: Three possible conclusions can be drawn from these results: 1) the peaks identified are spurious findings, 2) additional genes physically close to LMNA, PPARG, or within 9q, are involved in FPLD etiology, or 3) alternative disease causing mechanisms not identified by standard exon sequencing approaches, such as promoter mutations, alternative splicing, or epigenetics, are also responsible for FPLD.

\section{Modulating hedgehog and beta-catenin signaling in osteoarthritis}

\section{A. C. Lin, B. A. Alman University of Toronto, Toronto, ON}

Osteoarthritis (OA) is a common degenerative disease of the joints, characterized by cartilage deterioration and subchondral bone changes. Interestingly, these changes to the joint phenotype in OA are influenced by signalling pathways that are normal to limb development. For example, chondrocytes found in the articular cartilage of joints are under influence of betacatenin signalling, chondrocytes of growth plate cartilage are regulated by hedgehog signalling, and bone formation involves both beta-catenin and hedgehog signalling. We hypothesize that modulating these signalling pathways in OA can alter the joint phenotype, 
thereby reversing the cartilage and bone pathologies and improving articular cartilage regeneration. We aim to test our hypothesis using human OA samples, murine OA models, transgenic mice dysregulated for hedgehog and beta-catenin signalling, and limb explants cultures. The data generated will not only elucidate a fundamental understanding of cartilage fate regulation at the joint, but will also suggest novel treatments of osteoarthritis.

\section{Determinating the role of the E3 Ubiquitin Ligase Ariadne 2 in mammalian systems}

A.E. Lin*, A.Wakeham, A. You-Ten, G. Wood, T. W. Mak. Department of Medical Biophysics, Princess Margaret Hospital, University of Toronto, Canada.

Ubiquitination is a eukaryotic process of selective proteolysis, where a highly conserved ubiquitin protein is selectively added as a chain to the targeted to a protein for degradation. In recent years, the process of ubiquitination has been shown to be a critical mechanism that can affect essential signalling pathways, including apoptosis, cell cycle arrest and induction of the inflammatory response. Thus, alterations in the ubiquitination process can alter signalling pathways pivotal to numerous disease pathologies. This is clearly demonstrated in perturbations of ubiquitination in the $\mathrm{NF} x \mathrm{~B}$ giving rise to cancer and other immunological disease processes. To gain insight into pathways that require regulation by ubiquitination, our lab has directed focus on the highly conserved E3 ligase, Ariadne 2. Ariadne 2 is characterized as a putative RING finger E3 ligase and is part of the family of highly conserved RBR (RING-B-BoxRING) superfamily. The role of Ariadne 2 has been well studied in Drosophila melanogaster, however, little is known of the function of Ariadne 2 in mammalian systems. Therefore, the main objectives of the project are as follows: To determine the biological role of Ariadne 2, the role of Ariadne 2 in development and differentiation, and the consequences of in vivo loss of Ariadne 2 expression. We are currently investigating the role of Ariadne 2 as an E3 ligase and its involvement in the immune response.

To date, we have shown that Ariadne 2 is ubiquitously expressed, especially in the brain, heart, spleen and thymus. For in vivo loss of function analysis, mice were generated by homologous recombination to be deficient for Ariadne 2. These deficient mice die prematurely soon after birth, suggesting a critical role for Ariadne 2 in development and survival. We are currently focusing on the role of Ariadne 2 in development and it's role in immune pathologies, in particular, spontaneous autoimmunity, using both in vitro studies and in vivo models.

\section{Attention and grasping in Parkinson s disease: Ef- fects of treatment and disease stage}

\section{Cathy Lu, Oksana Suchowersky, Zelma Kiss, and An- gela $M$ Haffenden, Department of Clinical Neuro- sciences and Hotchkiss Brain Institute, University of Calgary, Calgary, Alberta}

Objective: To compare the attentional resources devoted to reach-to-grasp movements at different stages of Parkinson's disease (PD), on and off treatment, relative to intact controls.

Background: Reach-to-grasp movements are a critical component of activities of daily living. The grasping movements of patients with PD are characterized by a reliance on cues and visual feedback, not seen in the very automatic movements of intact controls (Azulay et al, 2006). PD patients appear to devote significant attentional resources to their movements; dual-task performance is a well-known area of difficulty for PD patients. To date, the role of attention in everyday reach-to-grasp movements has not been examined, though the implications for performance of activities of daily living are clearly considerable.

Methods: The performance of three patient groups [de novo $(n=11)$; moderate $(n=24)$; and surgical (STN DBS; $n=14)]$ was compared with age matched controls $(n=24)$ on a dual task paradigm involving grasping and a concurrent cognitive task designed to consume attention. Attentional resources were measured with standardized tests. Participants reached to grasp functional objects with handles (e.g. a comb). Handles were turned away from participants; an appropriate 
grasp was scored if they successfully picked up the object by the handle. Between and within group comparisons were made using ANOVA and t-tests.

Results: The control group and the de novo group not yet on medication displayed strong evidence of automaticity in their movements; when performing a challenging spatial imagery task, they made the same number of appropriate grasps as when they picked up the objects without a concurrent task. In contrast, for the moderate and the surgical groups, performing the concurrent task resulted in fewer appropriate grasps, and there was no improvement while on treatment (medication and stimulation, respectively). Only the surgical group showed decreased divided attention on standardized measures (>-0.7 SD below their normative group).

Conclusions: Grasping appears to shift from an automatic to an attention demanding process by the moderate stages of PD. This may be a coping mechanism designed to safely adapt to reduced motor function, or it may reflect pathology in the mechanisms underlying grasping movements.

References:

Azulay JP, Mesure S, and Blin O. 2006. J Neurol Sci, 248(1-2): 192-195.

\section{Characterization of low grade serous carcinoma of the ovary and its precursors}

Taymaa May, Department of Obstetrics \& Gynecology, Samuel Lunenfeld Research Institute, Institute of Medical Sciences, University of Toronto,

Monika Sharma, Microarray Centre, Ontario Cancer Institute,

Igor Jurisica, Division of Signaling Biology, Ontario Cancer Institute,

Barry Rosen, Joan Murphy, Division of Gynecological Oncology, Princess Margaret Hospital,

Patricia Shaw, Department of Laboratory Medicine and Pathology, University Health Network,

Theodore Brown, Department of Obstetrics \& Gynecology, Samuel Lunenfeld Research Institute, Institute of Medical Sciences, University of Toronto
Background: Low Grade Serous Carcinoma (LGSC) is a slow growing ovarian neoplasm affecting women in their 30s and 40s and is highly resistant to current chemotherapeutic regimens. Recent genomic hybridization and molecular biology studies have suggested that Ovarian Low Malignant Potential Tumor (LMP) may be a precursor lesion to LGSC as part of the type I pathway of ovarian carcinogenesis (Singer et al. Am Jo Path. 2002. 160;4:1223-1228). In addition, the significance of micropapillary features within LMP is being extensively studied as these features may indicate a more aggressive tumor behavior. (Seidman et al. Hum. Path. 1:539, 2000, Staebler et al., Hum. Path. 22:47, 2002).

Hypothesis: We propose to study the expression profiles of LMP, LMP with micropapillary features (LMP-MP) and LGSC. We hypothesize that given its increased aggressive tumor behaviour, LMP-MP may exhibit a genetic profile that is similar to LGSC and not LMP and may represent an intermediate lesion in the malignant transformation of LMP into LGSC. Genes that are differentially expressed between the tumors will be studied in an attempt to identify those involved in carcinogenesis.

Materials \& Methods: Snap-frozen tissue samples from primary ovarian tumors, diagnosed as LMP $(n=19)$, LMP-MP $(n=8)$, or LGSC $(n=12)$ were selected from the Toronto Ovarian Tissue Bank. Laser Capture Microdissection was used to separately isolate epithelial cells from tumor specimens. RNA was extracted, amplified, reverse transcribed to cDNA and hybridized to Affymetrix U133 Plus 2 arrays. Following normalization, the expression data was analyzed by Significance Analysis of Microarrays (SAM) as an initial step. Further analysis using Array Assist and Binary Tree Structured Vector Quantization are underway. Integration of the list of differentially expressed genes with a database of known and predicted protein-protein interactions will be used to select functionally related genes for validation and functional studies. Validation will include both real-time quantitative PCR and immunohistochemistry using tissue microarrays. We will then use in vitro models to initially determine the impact of these key genes on proliferation, cell motility, and/or invasion. For those 
genes we suspect as playing a key role in malignant transformation, we will attempt to alter expression in cultured ovarian epithelial cells and determine the impact on colony forming ability in soft agar and/or anchorage independent growth.

Preliminary Results: A total of 40 tumor samples have been profiled. Preliminary SAM analysis has indicated 134 probe sets (representing genes) as differentially expressed between LMP and LGSC, 47 genes between LMP and LMP-MP, and 180 genes between LMP and LMP-MP+LGSC. No differential gene expression was detected between LMP-MP and LGSC at a false discovery rate below $89 \%$.

Significance: These initial findings appear to support our hypothesis that LMP-MP is genetically similar to LGSC. Further analysis of the individual tumors' genetic profiles is underway, which may allow us to identify specific markers to refine their pathological diagnosis. In addition, we will attempt to identify genes that are differentially expressed between the non-invasive disease (LMP) and the invasive tumors (LMP-MP and LGSC). We propose that these genes will likely be involved in malignant transformation. We will use a bioinformatics approach and integrate these selected proteins with the list of 1732 potential secreted proteins identified by Welsh et al (Proc Natl Acad Sci U.S.A 100:3410, 2003) to highlight potential serum markers for early stage disease. Furthermore, we may be able to identify markers that would allow us to predict which low malignant potential tumors are more likely to progress to an aggressive neoplasm, which would allow clinicians to tailor medical and surgical treatments according to the patient's individual risk of progressing to a frank malignancy. Lastly, we hope to identify potential molecular therapeutic targets that may lead to the development of novel treatments for LGSC, which would improve patient management and overall survival.

\section{Memory from one-trial training is resistant to ex- tinction in Lymnaea Stagnalis}

\author{
Kara Murias, Martin Amarell, Ken Lukowiak. \\ Hotchkiss Brain Institute, University of Calgary, \\ Canada
}

Background: Memories that follow a traumatic event or extreme stress have been shown in some cases, to be particularly resistant to therapies meant to reduce their impact on patients. Two methods shown to decrease memories in laboratory tests are disruption after reactivation and extinction training. Newly formed memories undergo a period of stabilization, during which they are susceptible to amnesia treatments. Over a period of time memories become stabilized and can no longer be disrupted. However memories that are retrieved are returned to a labile state that must undergo a process of 'reconsolidation'. Also, many memories can be occluded by 'extinction training', which consists of withholding the training stimulus in the training environment resulting in a new memory that overshadows the original training.

Methods and Results: Using the Lymnaea stagnalis model system we show that memories following an extreme aversive stimulus demonstrate resistance to manipulation by these methods. Lymnaea stagnalis are fresh-water pond snails that can breathe either cutaneously or aerially through an orifice (pneumostome). Snails can form a long-term memory (LTM) to suppress pneumostome opening after operant conditioning consisting of either multiple sessions of repeated tactile stimulation to the orifice area each time the snail attempts to open its pneumostome or a single applications of $25 \mathrm{mM} \mathrm{KCl}$ stimulus contingent with pneumostome opening (one-trial training; 1TT). The LTM formed following one-trial training has many of the same characteristics as memory formed following repetitive tactile training. Specifically, both are dependent on new mRNA synthesis in the circuit that controls aerial respiration and both can be blocked by cooling immediately after training. However, we show that memories in Lymnaea that form after a single, highly aversive stimulus, unlike LTM after repetitive training, aren't disrupted after reactivation. We also 
attempted to extinguish the 1TT memory by placing the snails in the training beaker and not applying the $\mathrm{KCl}$ stimulus when they opened their pneumostome. When repetitive training was employed, extinction sessions such as these resulted in naïve levels of aerial respiration i.e. occlusion of the operantly trained memory.

Conclusions: Therefore, memory after 1TT is more resistant to suppression by extinction training than memories formed after less aversive stimuli. Further research will attempt to determine the cellular mechanism that causes the memory to be particularly resilient.

\section{Response of human osteoblast-like cells to fluid flow shear: A potential role for the microtubule network and primary cilium}

Kenneth A. Myers, Dr. Jerome B. Rattner, Dr. Nigel G. Shrive, Dr. David A. Hart, McCaig Centre for Joint Injury \& Arthritis Research, Alberta Bone \& Joint Health Institute, University of Calgary

Introduction: A limited understanding of the cellular mechanisms governing bone mechanotransduction has inhibited the development of clinical treatments for a variety of bone disorders, including osteoporosis, osteoarthritis and microgravity-associated bone atrophy. The cytoskeleton is thought to play a role in cellular mechanotransduction, however the exact mechanism in bone cells has not yet been clearly elucidated. Studies involving cytoskeletal inhibitors have not generally considered secondary effects on cellular organelles such as the primary cilia. These cellular projections could account for the disparity between shear stresses predicted to occur in vivo and the minimum threshold of membrane deformation required to elicit a cellular response in vitro.

Methods: MG-63 (human osteoblast-like) cells were cultured in vitro. Cultures were exposed to intermittent cyclic fluid flow shear stress (1 Pa amplitude), for 8 or $12 \mathrm{hrs}$. Some cultures were loaded in the presence of nocodazole (a microtubule inhibitor) or cytochalasin D (an actin filament inhibitor). The cellular response was analyzed through RT-PCR as- sessment of messenger RNA levels for specific molecules related to matrix metabolism. The effects of drug treatments on cytoskeletal disorganization and the primary cilia were assessed with immunocytochemistry and electron microscopy.

Results: In untreated cultures, shear stress was associated with significant increases in mRNA levels for collagen I and matrix metalloproteinases 1 and 3, for both time points assessed. These increases were maintained in cultures loaded in the presence of cytochalasin D, but were almost completely abrogated in nocodazole-treated cultures. Cytoskeletal inhibitors exerted some dose-dependent effects on length and structure of primary cilia in MG-63 cells.

Conclusions: The microtubule network appears to be necessary for some shear-induced responses of osteoblast-like cells. MG-63 cells possess primary cilia, organelles that could amplify fluid flow shear, accounting for some apparent contradictions between studies related to osteoblast mechanosensitivity. Since these structures are composed of microtubules, the observation that microtubule disruptors inhibit the shear response of osteoblast-like cells suggests the primary cilium may have a role in osteoblast mechanotransduction. The effects of cytoskeletal inhibitors on cilium structure may explain the conflicting results of earlier mechanotransduction studies.

\section{Examination of the dynamics of global DNA meth- ylation pattern establishment during spermato- genesis}

Kirsten Niles, MD/PhD Program, McGill University, Montreal Children's Hospital Research Institute and Departments of Pediatrics, Human Genetics and Pharmacology \& Therapeutics, McGill University, Montreal, QC, Sophie La Salle, Christopher Oakes, Jacquetta Trasler, Montreal Children's Hospital Research Institute and Departments of Pediatrics, Human Genetics and Pharmacology \& Therapeutics, McGill University, Montreal, QC

Background: DNA methylation is an epigenetic modification involved in gene expression, genome stability, 
and genomic imprinting. In the male, methylation patterns are initially erased in primordial germ cells (PGCs) as they enter the gonadal ridge; methylation patterns are then acquired on $\mathrm{CpG}$ dinucleotides during gametogenesis. Correct pattern establishment is essential for normal spermatogenesis. To date, the characterization and timing of methylation pattern acquisition in PGCs has been described using a limited number of specific gene loci. This study aimed to describe DNA methylation pattern establishment dynamics during male gametogenesis through global methylation profiling techniques in a mouse model.

Methods: Using a chromosome based approach, primers were designed for 24 regions spanning chromosome 9; intergenic, non-repeat, non- $\mathrm{CpG}$ island sequences were chosen for study based on previous evidence that these types of sequences are targets for testis-specific methylation events. The percent methylation was determined in each region by quantitative analysis of DNA methylation using real-time PCR (qAMP). The germ cell-specific pattern was determined by comparing methylation between spermatozoa and liver. To examine methylation in developing germ cells, spermatogonia from 2 day- and 6 day-old Oct4-GFP (green fluorescent protein) mice were isolated using fluorescence activated cell sorting.

Results: As compared to liver, four loci were hypomethylated and five loci were hypermethylated in spermatozoa, supporting previous results indicating a unique methylation pattern in male germ cells. Only one region was hypomethylated and no regions were hypermethylated in day 6 spermatogonia as compared to mature spermatozoa, signifying that the bulk of DNA methylation is established prior to type A spermatogonia. The methylation in day 2 spermatogonia, germ cells that are just commencing mitosis, revealed differences of $15-20 \%$ compared to day 6 spermatogonia at five regions indicating that the most crucial phase of DNA methylation acquisition occurs prenatally.

Conclusion: Together, these studies provide further evidence that germ cell methylation patterns differ from those in somatic tissues and suggest that much of methylation at intergenic sites is acquired during prenatal germ cell development. (Supported by CIHR)

\section{The role of CRMP4 in nerve regeneration}

\section{Stephan Ong Tone, Yazan Z. Alabed, Alyson E. Four-} nier, $\mathrm{MD} / \mathrm{PhD}$ Program, McGill University, Department of Neurology and Neurosurgery, Montreal Neurological Institute

The inability of CNS neurons to regenerate and reform functional connections following spinal cord injury has devastating clinical consequences. The failure of CNS neurons to spontaneously regenerate following injury can be partially attributed to the expression of neurite outgrowth inhibitory myelin associated inhibitors (MAIs). MAIs signal through a tripartite receptor complex to activate the cytosolic protein RhoA and influence cytoskeletal dynamics. RhoA antagonists promote neuronal survival and regeneration in animal models of nerve injury. However, RhoA's potential as a therapeutic target may be limited by its widespread roles in multiples cellular processes and cell types. In an attempt to discover more specific therapeutic targets to promote nerve regeneration, our lab identified the cytosolic phosphoprotein CRMP4b (Collapsin Response Mediator Protein 4b) as a protein that functionally interacts with RhoA to mediate neurite outgrowth inhibition. siRNA-mediated knockdown of CRMP4 and blockade of the RhoA-CRMP4b interaction with a competitive peptide (C4RIP) attenuates myelin-dependent neurite outgrowth inhibition. Analysis of the proximal tip of extending axons (growth cones) by time lapse video microscopy reveals that C4RIP regulates filopodial dynamics indicating that C4RIP modulates the actin cytoskeleton. We are currently investigating the in vivo roles of CRMP4 in regeneration in an optic nerve injury model by developing readily deliverable C4RIP and a CRMP4 knockout mouse. Elucidating the role of CRMP4 in nerve regeneration may provide insight into the molecular mechanisms following nervous system injury. 


\section{Heparin induces amyloid formation in cultured human islets}

Potter K, MD/PhD Program, and Child and Family Research Institute, University of British Columbia, Vancouver, BC,

Park K, CB Verchere, Child and Family Research Institute, University of British Columbia, Vancouver, $\mathrm{BC}$

Background: Pancreatic islet transplantation offers improved glycemic control in type 1 diabetic patients above standard insulin therapy, ideally minimizing macro- and microvascular complications of diabetes mellitus. However success is limited thus far, with fewer than $10 \%$ of patients retaining insulin independence at two years post-transplantation. In addition to immune rejection, many non-immune factors may promote long-term graft secretory dysfunction and loss of viable graft mass. One such important nonimmune factor may be the formation of islet amyloid, a pathologic lesion of the islet in type 2 diabetes that contributes to the progressive loss of $b$ cells in that disease and that has been shown to form rapidly in human islets transplanted into NOD.scid mice. Amyloid deposits are composed primarily of the $b$ cell secretory product islet amyloid polypeptide (IAPP), are cytotoxic, and develop in environments in which b cells are stressed. Heparin sulfate is used as an anticoagulant in clinical islet transplantation and to prevent the instant blood-mediated inflammatory reaction (IBMIR), which occurs upon contact between islets and blood and may destroy a substantial proportion of the grafted islet mass. However, heparin is also known to stimulate amyloid fibril formation.

Methods: To determine whether heparin may enhance amyloid formation in human islets and contribute to graft failure, we cultured isolated human islets in the presence or absence of heparin sulfate (42 and 420 units $/ \mathrm{ml}$ ) for 2 weeks in $11.1 \mathrm{mM}$ glucose.

Results: Histological assessment of sections of cultured islets for the presence of amyloid (by thioflavin $\mathrm{S}$ staining) revealed a marked, concentrationdependent increase in amyloid deposition following culture in the presence of heparin. Quantitative analy- sis of these sections showed that the proportion of islet area comprised of amyloid was increased approximately 2 -fold $(0.15 \% \pm 0.12 \%$ vs $0.46 \% \pm 0.15 \%$ of islet area) following culture in 42 units $/ \mathrm{ml}$ heparin, and the proportion of islets in which amyloid was detectable (amyloid prevalence) was also increased (35\% $\pm 24 \%$ vs $68 \% \pm 10 \%$ of islets). At 420 units $/ \mathrm{ml}$ heparin, the amyloid area was even greater $(0.23 \% \pm 0.15 \%$ vs $0.97 \% \pm 0.42 \%$ of islet area) as was the amyloid prevalence $(53 \% \pm 29 \%$ vs $81 \% \pm 14 \%$ of islets). To affirm that heparin can stimulate IAPP fibrillogenesis and enhance IAPP toxicity, we incubated synthetic human IAPP in the presence of heparin and measured amyloid formation in real time by thioflavin T fluorescence, and cell toxicity by Alamar blue viability assay in transformed rat (INS-1) B-cell cultures. Heparin stimulated IAPP fibril formation and increased death of INS-1 cells exposed to IAPP $(78.2 \% \pm 10.9 \%$ vs $51.8 \% \pm 12.2 \%$ of control viability), suggesting that heparin stimulates IAPP aggregation and toxicity. Remarkably, preliminary assessment of human islets cultured in heparin did not show increased islet cell death by TUNEL staining or loss of insulin immunostaining.

Conclusion: In summary, heparin increases amyloid formation in cultured human islets. Although our preliminary data does not suggest that heparininduced amyloid formation contributes to islet cell death, we speculate that heparin-induced amyloid formation may contribute to graft dysfunction and that caution should be used in the clinical application of this drug in islet transplantation.

\section{Stepping up regulatory mechanisms of GLUT4 traffic in L6 skeletal muscle cells}

V.K. Randhawa, Programme in Cell Biology, Hospital for Sick Children, Toronto, Canada; Department of Biochemistry, University of Toronto, Canada, I. Talior-Volodarsky, Programme in Cell Biology, Hospital for Sick Children, Toronto, Canada,

A. Klip, Programme in Cell Biology, Hospital for Sick Children, Toronto, Canada; Department of Biochemistry, University of Toronto, Canada 
Insulin increases glucose uptake into muscle and fat by enhancing GLUT4 glucose transporter externalization; a process requiring input from Akt and actin. Downstream of phosphatidylinositol-3-kinase, insulin signaling bifurcates into Akt and actin activating arms. Akt-mediated phosphorylation of the Rab-GAP AS160 is required for gain in surface GLUT4 by insulin. However, little is known of the mechanism(s) by which AS160 and/or actin dynamics modulate GLUT4 traffic in muscle. We recently showed that GLUT4 arrival and/or fusion can be regulated by insulin signaling molecules and phospholipids. Using 'rounded up' L6 myoblasts stably expressing GLUT4myc, we find that transient expression of a nonphosphorylatable mutant of AS160 (AS160-4P) abrogates the surface fusion of GLUT4myc and partially reduces its sub-membranous accumulation. In contrast, tetanus toxin-mediated cleavage of VAMP2 inhibits GLUT4myc fusion but not arrival to the plasma membrane. Conversely, disrupting actin dynamics with Latrunculin B or silencing expression of a cytoskeletal protein a-actinin4 precludes the insulininduced cortical build-up of GLUT4myc. These data suggest that AS160 and actin dynamics impinge on distinct stages of insulin-regulated GLUT4 traffic: AS160 may contribute to peripheral retention and is essential for GLUT4myc vesicle docking/fusion. It will be interesting to note which Rabs facilitate these AS160-dependent events. Actin dynamics instead may allow GLUT4 vesicle movement to the cell surface and/or its retention, presumably via cortical anchoring mechanisms involving a-actinin4, whilst VAMP2 has a major role in GLUT4 vesicle fusion. Indeed, defects in AS160 phosphorylation and actin dynamics are associated with insulin resistant states. Thus, discerning which steps of GLUT4 traffic are modulated by these inputs may help elucidate strategies to bypass insulin resistance.

\section{Intestinal microbiota balance modulates host sus- ceptibility to infection with enteric pathogens}

\author{
Sekirov I, MD/PhD Program, and Michael Smith \\ Laboratories, University of British Columbia, Van- \\ couver, BC
}

Tam N, Robertson M, Lupp C, B Finlay, Michael

Smith Laboratories, University of British Colum-

bia, Vancouver, BC

Background: During our lifetimes we develop a very complex set of interactions with the multitude of microorganisms colonizing our bodies. In the gastrointestinal system, the microbiota is highly important for morphological development, nutrition, and protection against infectious diseases. The gastrointestinal pathogens, enterohemorrhagic and enteropathogenic Escherichia coli (EHEC and EPEC) and Salmonella enterica serovar Typhimurium (ST) are food-borne pathogens that cause much morbidity and mortality worldwide. Citrobacter rodentium $(\mathrm{Cr})$ is a mouse pathogen that is used in small animal models to mimic EHEC and EPEC infections.

Methods: We began to characterize the contribution of intestinal microbiota to the progression of these infections. Two main phyla comprise the majority of mouse intestinal microbiota: Bacteroidetes and Firmicutes. Bacteria from a number of additional phyla are also present in smaller numbers; among them $\gamma$-Proteobacteria class, belonging to Proteobacteria phylum, is note-worthy as this class harbours many intestinal pathogens, such as ST and $\mathrm{Cr}$. The mouse intestinal microbiota was perturbed using tetracycline (Tet) and streptomycin ( $\mathrm{Sm}$ ) to increase the proportion of Bacteroidetes in the colonic microbiota, and using vancomycin (Vanc) to create a predominance of Firmicutes. The mice with this perturbed microbiota were infected with ST to investigate the resultant pathology and virulence characteristics, and any additional shifts in microbiota as a result of infection.

Results: Treatment of mice with Sm and Vanc was found to decrease the resistance of mice to colonization with ST, while Tet-treated mice exhibited unchanged colonization resistance. Treatment of mice with gradually increasing doses of $\mathrm{Sm}$, which gradu- 
ally augmented the proportion of CFB bacteria in the microbiota, resulted in progressively increasing colonization of mice by ST, as well as a step-wise increase in the ST-induced typhlitis, associated with higher levels of inflammatory markers IL-6 and KC. The increasing levels of ST colonization following both Sm and Vanc treatment were associated with an increase in the proportion of $\gamma$-Proteobacteria in the cecal and colonic microbiota, as well as a decrease in the total bacterial numbers in both organs.

Conclusions: It is evident that the intestinal microbiota plays a significant role in the host's response to infection with enteric pathogens, and its composition and numbers are also affected by the offending bacteria. Elucidation of the details regarding the contribution of the microbiota to infectious disease progression will offer novel targets for the future design of superior prevention and treatment methods.

\section{Development of a thermally responsive peptide for sustained deliver of solyble TNF receptor II to at- tenuate inflammatory events associated with radi- culopathy}

Mohammed F. Shamji, Dept of Biomedical Engineering, Duke Univ, Div of Neurosurgery, Dept of Surgery, The Ottawa Hospital,

Odelia Ghodsizadeh, Dept of Biomedical Engineering, Duke Univ,

Allan H. Friedman, Div of Neurosurgery, Dept of Surgery, Duke Univ Medical Center, Durham, NC William J. Richardson, Div of Orthopaedic Surgery, Dept of Surgery, Duke Univ Medical Center, Durham, NC

Ashutosh Chilkoti, Dept of Biomedical Engineering, Duke Univ,

Lori A. Setton, Depts of Biomedical Engineering and Surgery, Duke Univ

Background: Tumor necrosis factor alpha (TNF $\alpha)$ is a cytokine that may mediate inflammatory histopathology of the dorsal root ganglion following lumbar disc herniation. ${ }^{1}$ Soluble TNF receptor II (sTNFRII) competitively binds TNFa with clinical value for painful radiculopathy. ${ }^{2}$ Bioactive peptides expressed with elastin-like polypeptides (ELP) fusion partners gain a thermally responsive domain, by which they can undergo hydrophobic collapse and separate from solution to aggregate at physiological temperatures. ${ }^{3}$ Protein release from such a depot may locally sustain drug presence, an effect demonstrated for non-fusion ELP after intra-articular injection. ${ }^{4}$

Methods: We expressed sTNFRII fused to ELP to demonstrate potential bidomain functionality.

Protein Expression. A gene encoding ELP(VPGVG) 60 was subcloned adjacent to the sTNFRII and transformed into E.coli for expression. ${ }^{5}$ Protein Safety. Endotoxin content of purified fusion protein was evaluated using a limulus amebocyte lysate endpoint assay and compared to non-fusion ELP using a two-tailed Student's t-test. Thermal Responsiveness. Dynamic light scattering evaluated the inverse thermal phase transition behaviour of ELP-sTNFRII, and absorbance spectrophotometry quantified the in vitro depot release at $37^{\circ} \mathrm{C}$. Fusion Domain Function. Anti-TNF $\alpha$ bioactivity was assessed by the in vitro inhibition of TNF $\alpha$-induced glutamate production by microglia. Single-factor ANOVA analyzed treatment differences for ELP-sTNFRII, commercial sTNFRII (positive control), and non-fusion ELP (negative control).

A $44 \mathrm{kDa}$ recombinant fusion protein was expressed from E. coli and purified by inverse transition cycling.

Results: Measured endotoxin content for ELPsTNFRII was comparable to ELP alone ( $p<0.01$ ), well below FDA levels for biomedical implants. The fusion protein underwent a thermally-induced phase transition and formed observable aggregates of 240 $\mathrm{nm}$ upon heating to physiological temperatures $\left(\mathrm{T}_{\mathrm{t}}=\right.$ $32^{\circ} \mathrm{C}$ ). Slow release was observed from this depot with a time constant of $21 \pm 3$ hours. The fusion protein demonstrated anti-TNF $\alpha$ activity in vitro by attenuating TNF $\alpha$-induced microglial glutamate production, albeit requiring a greater concentration than the free antagonist to achieve the same effect. $(\mathrm{p}<0.01)$.

Conclusion: Fusion of a sTNFRII protein to an ELP can serve to generate a thermally-induced drug depot that may sustain anti-cytokine activity of agents 
delivered locally to a nerve region. Further directions may involve studying in vivo biodistribution after perineural delivery of ELP and in vivo disease modifying activity of this agent.

\section{The Dynactome-investigating dynamic network motifs of kinases}

Jonathan So, Kelly Elder, Karen Colwill, Rune Linding, Tony Pawson. Samuel Lunenfeld Research Institute, Toronto

Network motifs of kinases phosphorylating other kinases represent a unique control system for cellular functions. Recently, we described the bioinformatics tool NetworKIN (Linding et al, Cell in press) which accurately predicts kinase-substrate pairs. With these predicted feedback and feed-forward motifs of kinases, we characterize their effect through overexpression and monitoring of the phosphorylation of downstream signalling targets, such as MAP kinases. To understand the behaviour of this system in signal integration and cellular decision-making, we stimulate cells over-expressing a kinase with orthogonal signals, such as apoptosis promoting vs. growth-inducing cytokines, allowing for a more comprehensive coverage of signalling space (Janes et al., Science 2005). We present some feedback and feed-forward motifs found in the kinase-kinase network, and describe efforts to characterize dynamic phosphorylation sites in the context of orthogonal signals.

\section{Prevalence of metabolic syndrome in never treated mood disordered patients}

\section{Valerie Taylor, Dept. Medical Science, McMaster} University, Dept. Psychiatry and Behavioral Neuroscience, McMaster University,

Glenda M. MacQueen, Dept. Psychiatry and Behavioral Neuroscience, McMaster University

Bipolar disorder and major depression are lifeshortening illnesses. Unnatural causes such as suicide and accidents account for only a portion of this premature mortality ${ }^{1}$ Research is beginning to identify that mood disordered patients have a higher incidence of metabolic syndrome, an illness characterized by dyslipidemia, impaired glucose tolerance, hypertension and obesity. ${ }^{2}$ Metabolic syndrome is associated with an increased risk for a variety of physical illnesses.

Hypothesis: Never treated patients with mood disorders have preexisting elevations in the prevalence of the component variables of metabolic syndrome. Central obesity will be especially elevated, predicting increased premature mortality.

Methods: We assessed never treated patients with mood disorders for metabolic syndrome and its component variables. Patients were assessed at baseline and followed up at 6-month intervals. All psychiatric pharmacotherapy was documented. Body mass index (BMI) was also obtained and the percentage of deaths attributable to overweight and obesity was calculated using the population attributable risk (PAR). $[\mathrm{PAR}=\Sigma$ [P (RR-1)/RR]

Results: Prior to the initiation of treatment, patients did not differ from population norms with respect to metabolic syndrome or BMI. At 2-year follow-up, BMI had increased for unipolar patients 2.02 points and 1.92 points for bipolar patients. $(\mathrm{p}<.001)$ This increase in BMI predicted an increase in mortality of $19.4 \%$.

Conclusion: An increase in visceral obesity is often the first component of metabolic syndrome to appear and may indicate the initiation of this disease process prematurely in this group. The increase in BMI places patients with mood disorders at risk for premature mortality and indicates a need for early intervention.

References

1.Osby U, Brandt L, Correia N, Ekbom A \& Sparen P. Excess mortability in bipolar and Unipolar disorder rin Sweden. Archives of General Psychiatry, 2001;58: 844850

2.Toalson P, Saeeduddin A, Hardy T \& Kabinoff G. The metabolic syndrome in patients with severe mental illness. Journal of Clinical Psychiatry, 2004; 6(4): 152-158 


\section{Mast cells release cytokines in response to media- tors produced by virus-infected epithelial cells}

Candy Tsang, and A.D. Befus. Pulmonary Research Group, Department of Medicine, University of Alberta, Canada

Background: Mast cells have long been recognized for their involvement in allergic diseases. In the last decade, the importance of mast cells in innate responses against bacteria has been established, but little is known about their contribution in viral infections. Mast cells are abundant at mucosal surfaces such as the lungs in close proximity to the epithelium. In the lung, the epithelium is a primary target for viral infections. Mast cells are secondarily exposed to newly formed virions released from epithelial cells. Mast cells have toll-like receptors (TLRs) that detect various pathogen components. Our first hypothesis is that viral TLR agonists will induce mast cells to release cytokines thought to be involved in viral infections. Both the pro-inflammatory cytokine IL-6 and the chemokine IL-8 are produced during viral infections. TGF- $\beta$ is an immunoregulatory cytokine that modulates the activity of various immune cells and could also play a role in viral infections.

Methods: We used polyI:C, a synthetic doublestranded RNA (dsRNA), as a TLR3 agonist, loxoribine as a TLR7 agonist, and unmethylated CpG DNA as a TLR9 agonist. We treated mast cells from the cell line HMC-1 (Human Mast cell-1) for 0.5 - 24hr with the TLR agonists and performed dose response studies for all stimuli. Supernatants from treated mast cells were measured for IL-6, IL-8, and TGF- $\beta$ by ELISA.

Results: Cytokine release was highest at the $24 \mathrm{hr}$ time point. Mast cells released IL-6, IL-8, and TGF- $\beta$ in response to the TLR3 agonist polyI:C in a dosedependent manner, but not to the other viral TLR agonists. PolyI:C $(10 \mu \mathrm{g} / \mathrm{mL})$ versus unstimulated controls significantly increased mast cell release of IL-6 $(224.7 \pm 57.4$ vs. $39.0 \pm 5.7, \quad \mathrm{p} \leq 0.001)$ and TGF- $\beta$ (240.2 \pm 28.9 vs. $116.1 \pm 16.7, \mathrm{p} \leq 0.05)$. PolyI:C induced release of IL-8 from mast cells was increased but not significant. Viral exposure also induces epithelial cells to produce type I interferons, IFN $\alpha$ and $\beta$. These interferons have potent antiviral activity, but also have effects on mast cells, decreasing mast cell adhesion to extracellular matrix and reducing co-stimulatory activity on T cells. Our second hypothesis is that IFN $\alpha$ and $\beta$ will induce mast cells to release cytokines similar to stimulation with polyI:C. Our preliminary data showed that IFN $\alpha$, IFN $\beta$, and IFN $\alpha$ and $\beta$ in combination induced a low level of IL- 8 and TGF- $\beta$ release from mast cells, but had no effect on IL-6 release.

Conclusion: HMC-1 responds to dsRNA, a TLR3 agonist produced in epithelial cells during viral replication, by releasing IL- 6 and TGF- $\beta$. HMC- 1 also responds to IFN $\alpha$ and $\beta$ by releasing IL- 8 and TGF- $\beta$, indicating that human mast cells respond to epithelial mediators produced during viral infections. Our results show that mast cells contribute to the innate response against viruses by responding to mediators released by virus-infected epithelial cells.

\section{Gene transfer of endothelial NO-synthase restores migratory capacity of endothelial progenitor cells from patients with coronary artery disease}

Michael R. Ward, Qiuwang Zhang, Duncan J. Stewart and Michael J.B. Kutryk. Terrence Donnelly Vascular Biology Laboratories, St. Michael's Hospital, University of Toronto, Toronto, Ontario

Autologous endothelial progenitor cells (EPCs) have been used extensively in the development of cellbased therapy for acute MI. However, EPCs isolated from patients with CAD and/or CAD risk factors have reduced regenerative activity compared to cells from healthy subjects. As in endothelial cells, endothelial NO synthase (eNOS) expression and subsequent NO production are believed to be critical determinants of EPC function. Recently, the ability of EPCs to migrate in vitro in response to chemotactic stimuli has been shown to predict their regenerative capacity in clinical studies. Therefore, we hypothesized that the regenerative function of EPCs from patients with or at high risk for CAD will be enhanced by overexpression of eNOS, as assessed by migratory capacity. 
Methods: EPCs were isolated from the blood of human subjects with CAD risk factors $(>15 \%$ Framingham risk score; FRS) ( \pm CAD) by Ficoll gradient separation and differential culture. Following 3 days in culture, cells were transduced using lentivirus vectors containing either eNOS or GFP (sham) at an MOI of 3 . The cells were cultured for an additional 5 days before being used in functional assays. Cell migration and chemotaxis in response to $\operatorname{VEGF}(50 \mathrm{ng} / \mathrm{mL})$ and SDF-1 (100 ng/mL) were assessed using a modified Boyden Chamber assay.

Results: Transduction at an MOI of 3 led to a $~ 90$ 100 -fold increase in eNOS mRNA expression and a 56 fold increase in eNOS protein expression, as assessed by qRT-PCR and Western Blotting. Moreover, there was a significant improvement in the migration of EPCs following eNOS transduction compared to sham-transduced EPCs in response to both VEGF $(44.3 \pm 8.4$ vs. $31.1 \pm 4.6$ cells/high power field; $n=10$, $\mathrm{p}<0.05)$ and SDF-1 $(51.9 \pm 11.1$ vs. $34.5 \pm 3.3$ cells/ HPF; $\mathrm{n}=10, \mathrm{p}<0.05)$.

Conclusions: These data show that the reduced migration capacity of EPCs isolated from patients with $\mathrm{CAD}$ and/or CAD risk factors can be significantly improved through eNOS overexpression in these cells. Thus, eNOS transduction of autologous EPCs may enhance their ability to restore myocardial perfusion and function following acute MI. We intend to further explore the regenerative potential of eNOStransduced EPCs using various in vitro and in vivo models.

\section{The warburg effect and tumour cell survival in human GBM}

Wolf A, Mukherjee, Arthur \& Sonia Labatts Brain Tumour Center, Hospital for Sick Children, Guha A, Arthur \& Sonia Labatts Brain Tumour Center, Hospital for Sick Children; Div. of Neurosurgery, Western Hospital, Univ. of Toronto

Introduction: GBMs are resistant to apoptosis induced by the hypoxic microenvironment and standard therapies including radiation and chemotherapy. We postulate that the Warburg effect, a preferential glycolytic phenotype of tumor cells even under aerobic conditions, plays a role in these aberrant pro-survival signals. In this study we quantitatively examined the expression profile of hypoxia-related glycolytic genes within pathologically- and MRI-defined "centre" and "periphery" of GBMs. We hypothesize that expression of hypoxia-induced glycolytic genes, particularly hexokinase 2 (HK2), favours cell survival and modulates resistance to tumour cell apoptosis by inhibiting the intrinsic mitochondrial apoptotic pathway.

Methods: GBM patients underwent conventional T1-weighted contrast-enhanced MRI and MR spectroscopy studies on a 3.0T GE scanner, prior to stereotactic sampling (formalin and frozen) from regions which were T1-Gad enhancing ("centre") and T2positive, T1-Gad negative ("periphery"). Real-time qRT-PCR was performed to quantify regional gene expression of glycolytic genes including HK2. In vitro functional studies were performed in U87 and U373 GBM cell lines grown in normoxic (21\% pO2) and hypoxic $(<1 \%$ pO2) conditions, transfected with $\mathrm{HK} 2$ siRNA followed by measurement of cell proliferation (BrdU), apoptosis (activated caspase 3/7, TUNEL, cytochrome c release) and viability (MTS assay).

Results: There exists a differential expression profile of glycolytic enzymes between the hypoxic center and relatively normoxic periphery of GBMs. Under hypoxic conditions, there is increased expression of HK2 at the mitochondrial membrane in GBM cells. In vitro HK2 knockdown led to decreased cell survival and increased apoptosis via the intrinsic mitochondrial pathway, as seen by increased mitochondrial release of cytochrome-C.

Conclusions: Increased expression of HK2 in the centre of GBMs promotes cell survival and confers resistance to apoptosis, as confirmed by in vitro studies. In vivo intracranial xenograft studies with injection of HK2-shRNA are currently being performed. HK2 and possibly other glycolytic enzymes may provide a target for enhanced therapeutic responsiveness thereby improving prognosis of patients with GBMs. 


\section{An analysis of the adaptive immune response to- wards an embryonic stem cell graft}

Douglas $W u$, University of Alberta and the 2Nuffield Department of Surgery, University of Oxford, UK, Kathryn Wood, Nuffield Department of Surgery, University of Oxford, UK

Background: Although clinical transplantation has had enormous impact on the treatment of premature organ failure, shortage of donor organs continues to be a crucial limiting factor. Embryonic stem cells represent an attractive potential source of replacement tissue because of their inherent pluripotentiality and ability to self-renew. However, before any ES cellbased cellular replacement strategies can be considered, many issues must be addressed. Among these is an evaluation of the potential immune response elicited by any ES cell graft. Because ES cells express very low levels of MHC class I and no MHC class II, their immunogenicity has been questioned. Here we utilize a BM3 TCR transgenic model to analyze the adaptive immune response against an ES cell graft in vivo.

Methods: BM3 CD8 TCR-tg T cells (H2K background) specific for the MHC class I molecule $\mathrm{H} 2 \mathrm{~K}^{\mathrm{b}}$ were labelled with CFSE and adoptively transferred into CBA rag recipients. The following day, ES cells derived from a CBA, B6, or CBK background were implanted beneath the kidney capsule of adoptively transferred mice. Response of the CD8 T cells was measured via CSFE division profiling and graft infiltration.

Results: CFSE division profile of naïve BM3 CD8 $\mathrm{T}$ cells was unaltered by the presence of either a syngeneic or an allogeneic ES cell graft. These naïve cells were also unable to recognize and infiltrate either a syngeneic or allogeneic ES cell graft on days 5 and 10 post-implantation, despite strong expression of the MHC class I molecule $\mathrm{H} 2 \mathrm{~K}^{\mathrm{b}}$ by engrafted allogeneic ES cells. On the other hand, $\mathrm{H} 2 \mathrm{~K}^{\mathrm{b}}+$ islets begun to be infiltrated by day 5 , and were obliterated by a vigorous allogeneic response by day 10 . When $\mathrm{H} 2 \mathrm{~K}^{\mathrm{b}}+$ islets were implanted into the same kidney as allogeneic ES cells (opposite poles), islet grafts were rapidly in- filtrated by CD4 and CD8 T cells and destroyed, but ES cell grafts exhibited markedly reduced cellular infiltrate. In contrast to naïve BM3 CD8 T cells, however, activated cells recognized and mounted an aggressive cytotoxic response against an allogeneic ES cell graft which could be detected by day 6 and resulted in complete graft destruction by day 10 .

Conclusions: Under certain circumstances, an ES cell graft may have reduced immunogenicity as compared with other conventional tissue or solid organ allografts. This may be due to their lack of passenger APC, which may in turn cripple their ability to elicit a robust allogeneic response via the direct pathway of allorecognition. However, because of their strong upregulation of allogeneic MHC class I molecules after transplantation, they are still likely to elicit a significant rejection response when transplanted into recipients replete with both $\mathrm{CD} 4$ and CD8 T cells.

\section{Distribution and expression of transgene green fluorescent protein in mice survived up to four weeks following in utero gene therapy}

\section{PT Yang, L Huang, WW Jia , ED Skarsgard, C Sy, Division of Pediatric Surgery and Neurosurgery, Department of Surgery, University of British Co- lumbia, Vancouver, Canada}

Gene replacement offers a potential cure for degenerative disorders caused by a single gene deletion or mutation. Diagnoses of monogenic disorders in the fetus enable prenatal gene replacement which may be beneficial from the perspectives of host inflammatory/ immune response, efficacy and disease prevention.

Purpose: To evaluate the distribution and expression of reporter gene green fluorescent protein (GFP) in the tissues of mice survived up to one month following in utero gene therapy.

Methods: Vesicular Stomatitis Virus-G (VSV-G) pseudotyped lentiviral (LV) vector containing GFP was prepared via triple plasmid co-transfection. Time-mated CD-1 mice underwent individual amniotic sac injection with either $1 \times 10^{6} \mathrm{LV}$ particles or saline (controls) on gestational day 16 (term=21d), and were allowed to undergo spontaneous parturition. 
Pups were sacrificed on postnatal days 0, 7, 21 and 28, and neonatal and maternal tissues were analyzed for GFP transgene (by DNA polymerase chain reaction; PCR), and transgene expression by quantitative reverse transcriptase (QRT) PCR and immunohistochemistry (IHC).

Results: We observed selective transduction of neonatal tissues (trachea, lung, liver, heart, kidney, spleen, intestine, skeletal muscle), in pups undergoing in utero transfection with LV-GFP. Maternal tissues did not contain transgene despite exposure during amniotic injection. Although the numbers of pups analyzed at each postnatal time point was small, we observed variable persistence of GFP expression that appeared to be tissue specific (with persistent expression noted in intestine of 4 week old pups).

Conclusions: Neonatal tissue transfection occurs in a variety of tissues following amniotic injection with LV-GFP in this murine model of in utero gene therapy. Transgene persistence and expression patterns observed over the first 4 weeks of life may reflect tissue-specific genomic insertion of transgene that favors persistent transcription in select tissues.

\section{Regulation of huntingtin palmitoylation and its role in Huntington Disease}

Young FBJ, MD/PhD Program, and Centre for Molecular Medicine and Therapeutics, andChild and Family Research Institute, University of British Columbia, Vancouver, BC,

MR Hayden, Centre for Molecular Medicine and Therapeutics, and Child and Family Research Institute, University of British Columbia, Vancouver, $\mathrm{BC}$

Huntington's Disease (HD) is an autosomal dominant neurodegenerative disorder characterized by motor, cognitive, and psychiatric deficits and selective neuronal cell death. The causative mutation in HD is an expansion of the $\mathrm{N}$-terminal polyglutamine tract in huntingtin (htt), which results in altered trafficking of mutant htt and enhanced toxicity to striatal neurons.

Post-translational modification by the lipid palmitate has been shown to play a critical role in the traf- ficking and function of many proteins, including htt. It has been previously demonstrated that huntingtininteracting protein 14 (HIP14) is a palmitoyl transferase that palmitoylates htt. Previous characterization of HIP14 demonstrated a reduced interaction with mutant htt resulting in reduced palmitoylation, suggesting that palmitoylation may play a role in the pathogenesis of HD. Most recently, we have identified cysteine 214 as a major site of htt palmitoylation in the $\mathrm{N}$ terminus of htt, close to the site of polyglutamine expansion. It was demonstrated that mutation of this site, rendering htt palmitoylation-resistant, results in increased neuronal toxicity, enhanced inclusion formation, and in altered trafficking of htt. Remarkably, mutation of the palmitoylation site in wild type htt also resulted in enhanced toxicity similar to that seen in mutant htt. Together, these previous studies suggest a critical role of palmitoylation in htt trafficking and function.

Based on this preliminary work, we are characterizing the enzymatic regulation of huntingtin palmitoylation. Exploring htt palmitoylation in a number of existing and new mouse models imparts key insights into how this process is regulated in vivo. We are also exploring the relationship between palmitoylation and other post-translational modifications of htt. These studies will lead to an understanding of the regulation of palmitoylation of huntingtin in vivo, as well as setting the precedent to understand the general role of palmitoylation in a wide range of other human diseases. Ultimately, this may lead to identification of new therapeutic targets and treatments for patients.

F.B.J.Y. is supported by a Canadian Institutes of Health Research Walter and Jessie Boyd \& Charles Scriver - Child and Family Research Institute - UBC $\mathrm{MD} / \mathrm{PhD}$ Studentship Award. She also receives funding from the Michael Smith Foundation for Health Research as a Junior Trainee. 


\section{AUTHOR INDEX}

\section{Agapite J. See Gafuik et al.}

Aguilar H. The role of RHOA in calcium sensitization in human myometrial smooth muscle.

\section{Alabed YZ. See Ong Tomes et al.}

Albion C Dixon S, Nygard K, Reid C, Han V. Effects of maternal nutrient restriction on placental morphology and insulin-like growth factor system expression.

Aldosary F, Tremblay P, Hébert C, Blier P. Atomoxetine, but not paroxetine, blocks norepinephrine reuptake in depressed patients.

Alman BA. See Lin et al.

Altier C. See Khoseavavi et al.

Amarell M. See Murias et al.

Anderson S. See Berkhout et al.

Appleton T, Usmani S, Pitelka V, Henry J, Bernier S, Beier F. Global gene expression analyses in early experimental osteoarthritis reveal novel players in articular cartilage degeneration.

Astanehe A, Finkbeiner M, Jiang H, Dunn SE Profiling. YB-1 responsive genes in basal-like breast cancer cells BY CHIP-ON-CHIP reveals direct binding to PIK3CA.

\section{Atkinson-Leadbeater K. See Chen et al.}

Auer I, Mansoor A. See Howell et al.

Barrett L, Hirsch G, Gallant M, Howley C, Peltekian C, Grant M. The character of anti-HCV T cell responses differs between spontaneous and treatmentinduced viral clearance.

Befus AD. See Tsang et al.

Beier F. See Appleton et al.

Bendeck M, See Franco et al.

Bergeron JJM. See Jain et al.

Berkhout SG, Tyndall MW,Anderson S. Through the looking-glass: objectivity, interpretation, and the construction of social kinds as emerging issues in research ethics

Bernier S. See Appleton et al.

Blier P. See Aldosary et al.

Brenner BG. See Coutsinos et al.

Brown T. See May et al.

Burstein B, Qi X-Y, Calderone A, Nattel S. Rapid electrical pacing of cardiomyocytes alters the behavior of cardiac fibroblasts: implications for atrial fibrillation

\section{Calderone A. See Burstein et al.}

\section{Cao H. See Langtree et al.}

\section{Carter D. See Langtree et al.}

Chan AYM, Soltys C-LM, Dyck JRB. The role of Amp-activated protein kinase (AMPK) in the regulation of cardiac hypertrophy.

Chen YY. The metalloproteinase ADAM10 is required for retinal ganglion cell axon guidance in the developing visual system....

\section{Chilkoti A. See Shamji et al.}


Chin J. See Cool et al.

Christie B. See Eadie et al.

Colwill K,. See So et al.

Cool D, Sherebrin S, Izawa $\mathbf{J}^{\mathbf{2}}$, Chin J, Fenster A In Vitro validation of a 3-dimensional transrectal ultrasound system for prostate biopsies

\section{Cosio G. See Erdman et al.}

Coutsinos D, Invernizzi CF, Moisi D, Oliveira M, Brenner BG, Wainberg MA. Molecular characterization of the development of the K65r and M184v drug resistance mutations in subtype C HIV-1

Creider J. See Langtree et al.

Cygler M. See Jain et al.

\section{Demetrick D. See Howell et al.}

Der SS. See Hyrcza et al.

Dixon S. See Albion et al.

Dugani S, Paquin A, Kaplan DR, Miller.FD. Elucidating the role of p63 during development of the mammalian nervous system

Dunn SE. See Astanche et al.

Durbin AD, Somers GR, Forrester M, Hannigan GE, Malkin DA JNK-dependent switch determines the oncogenic or tumor suppressor activity of ILK.

\section{Dyck JRB. See Chan et al.}

Eadie B, Christie B. Abnormal neurogenesis in the hippocampus of a mouse model of fragile X syndrome.

Elder K. See So et al.
Erdman L, Cosio G, Patel SN, Grinstein S,. Kain KC. Innate inflammatory and phagocytic responses to plasmodium falciparum: linked processes or molecularly discrete pathways?

Fenster A. See Cool et al.

Finkbeiner M. See Astanche et al.

Finlay B. See Sekirov et al.

Forrester M. See Durbin et al.

Fournier AE. See Ong Tomes et al

Franco C, Hou G, Vogel W, Bendeck M. Targeted deletion of discoidin domain receptor $1(d d r l)$ decreases atherosclerosis, reduces inflammation and accelerates matrix accumulation in ldl receptor deficient mice.

Friedman AH. See Shamji et al.

Frohlich JJ. See Heslop et al.

Gafuik C, Agapite J, Steller H. A screen for suppressors of apoptosis identifies a novel gain of function mutation in drosophila RAS1

Gallant M. See Barrett et al.

Ghodsizadeh O. See Shamji et al.

Gilchrist N. See Jain et al.

Goldenberg NM, Grinstein S, Silverman M. Golgibound RAB34 is a novel member of the secretory pathway.

Grant M. See Barrett et al.

Grinstein S. See Erdman et al.

Grinstein S. See Goldenberg et al. 
Haffenden AM. See Lu et al.

Hameed S. See Khosravani et al.

Hamid J. See Khosravani et al.

Han V. See Albion et al.

Hannigan GE. See Durbin et al.

Hart DA See Myers et al.

Hébert C. See Aldosary et al.

Hegele RA. See Lahiry et al.

Hegele R. See Lanktree et al.

Hehr CL. See Chen et al.

Henry J. See Appleton et al.

Heslop CL, Frohlich JJ, Hill JS. Relative value of plasma nitrotyrosine for predicting mortality in patients with coronary artery disease.

Hill JS. See Heslop et al.

Hirsch G. See Barrett et al.

Hocking JC. See Chen et al.

Horsch D. See Lanktree et al.

Hou G, See Franco et al.

Howell JM, Luider J, Wong H, Perrizolo M, Demetrick D, Auer I, Mansoor A. High affinity IL-2 receptor (CD25) expression among Chronic Lymphocytic leukemia (CLL) patients is independent of mutational status and ZAP-70 positivity.

Howley C. See Barrett et al.
Hyrcza MD, Der SS, Ostrowski M. Differential expression of type I interferon genes in plasmacytoid dendritic cells from HIV-infected patients

Invernizzi CF. See Coutsinos et al.

Izawa $\mathrm{J}^{2}$. See Cool et al.

Jain MD, Nagaya H, Gilchrist N, Cygler M, Bergeron JJM. Spatial localization of unknown proteins in the endoplasmic reticulum predicts function

Jiang H. See Astanche et al.

Jirik FR. See Khosravani et al.

Jurisica I. See May et al.

Kain KC. See Erdman et al.

Kaplan DR. See Dugani et al.

Khosravani H, Zhang Y, Tsutsui S, Hameed S, Hamid J, Altier C, Jirik FR, Zamponi GR. Modulation of NMDA receptors by prion protein.

Kiss Z. See Lu et al.

Klip A. See Randhawa et al.

Kutryk MJB. See Ward et al.

Lahiry P, Robinson JF, Siu V, Puffenberger EG, Strauss KA, Hegele RA, Rupar CA. Genetic characterization of two autosomal recessive disorders, Majewski-like and cerebral atrophy syndrome.

Lanktree M, Robinson J, Creider J, Cao H, Carter D, Horsch D, Hegele R. A genome-wide linkage scan for familial partial lipodystrophy susceptibility genes in a German kindred.

La Salle S. See Niles et al. 
Lin AC, Alman BA. Modulating hedgehog and betacatenin signaling in osteoarthritis

Lin AE, Wakeham A, You-Ten A, Wood G, Mak

TW. Determinating the role of the E3 Ubiquitin ligase Ariadne 2 in mammalian systems.

Linding R. See So et al

Lu C, Suchowersky O, Kiss Z, Haffenden AM. Attention and grasping in Parkinson's disease: effects of treatment and disease stage.

Luider J. See Howell et al.

Lukowiak K. See Murias et al.

Lupp C. See Sekirov et al.

MacQueen GM. See Taylor et al.

Malkin DA, See Durbin et al.

Mansoor A. See Howell et al.

Mak TW. See Lin et al.

May T, Sharma M, Jurisica I, Rosen B, Murphy J, Shaw P, Brown T. Characterization of low grade serous carcinoma of the ovary and its precursors

McFarlane S. See Chen et al.

Miller.FD. See Dugani et al.

Mitchell BF. See Aguilar et al.

Moisi D. See Coutsinos et al.

Murias K, Amarell M, Lukowiak K. Memory from one-trial training is resistant to extinction in lymnaea stagnalis

Murphy J. See May et al.
Myers KA, Rattner JB, Shrive NG, Hart DA. Response of human osteoblast-like cells to fluid flow shear: a potential role for the microtubule network and primary cilium.

\section{Nagaya H. See Jain et al.}

Nattel S. See Burstein et al.

Niles K, La Salle S, Oakes C, Trasler J. Examination of the dynamics of global DNA methylation pattern establishment during spermatogenesis....

Nygard K. See Albion et al.

Oakes C. See Niles et al.

Ong Tone S, Alabed YZ, Fournier AE. The role of CRMP4 in nerve regeneration

Ostrowski M. See Hyrcza et al.

Paquin A. See Dugani et al.

Park K. See Potter et al.

Patel SN. See Erdman et al.

Pawson T. See So et al

Peltekian C. See Barrett et al.

Perrizolo M. See Howell et al.

Pitelka V. See Appleton et al.

Potter K, Park K, Verchere CB. Heparin induces amyloid formation in cultured human islets.

Puffenberger EG. See Lahiry et al.

Qi X-Y. See Burstein et al.

Oliveira M. See Coutsinos et al. 
Randhawa VK, Talior-Volodarsky I, Klip A. Stepping up regulatory mechanisms of Glut4 traffic in L6 skeletal muscle cells.

Rattner JB. See Myers et al.

Reid C. See Albion et al.

Richardson WJ. See Shamji et al.

Robertson M. See Sekirov et al.

Robinson JF. See Lahiry et al.

Robinson J. See Langtree et al.

Rosen B. See May et al.

Rupar CA. See Lahiry et al

Sekirov I, Tam N, Robertson M, Lupp C, Finlay B. Intestinal microbiota balance modulates host susceptibility to infection with enteric pathogens

Setton LA. See Shamji et al.

Shamji MF, Ghodsizadeh O, Friedman AH, Richardson WJ, Chilkoti A, Setton LA. Development of a thermally responsive peptide for sustained delivery of soluble TNF receptor II to attenuate inflammatory events associated with radiculopathy.

Sharma M. See May et al.

Shaw P. See May et al.

Sherebrin S. See Cool et al.

Shrive NG. See Myers et al.

Silverman M. See Goldenberg et al.

Siu V. See Lahiry et al.
So J, Elder K, Colwill K, Linding R, Pawson T. The dynactome-investigating dynamic network motifs of kinases.

Soltys C-LM. See Chan et al.

Somers GR. See Durbin et al.

Steller H. See Gafuik et al.

Stewart DJ. See Ward et al.

Strauss KA. See Lahiry et al.

Suchowersky O. See Lu et al.

Talior-Volodarsky I. See Randhawa et al.

Tam N. See Sekirov et al.

Taylor V, MacQueen GM. Prevalence of metabolic syndrome in never treated mood disordered patients

Trasler J. See Niles et al.

Tremblay P. See Aldosary et al.

Tsang C, Befus AD. Mast cells release cytokines in response to mediators produced by virus-infected epithelial cells

Tsutsui S. See Khosravani et al.

Tyndall MW. See Berkhout et al.

Usmani S. See Appleton et al.

Verchere CB. See Potter et al.

Vogel W, See Franco et al.

Wainberg MA. See Coutsinos et al.

Wakeham A. See Lin et al. 
Ward MR, Zhang Q, Stewart DJ, Kutryk MJB.

Gene transfer of endothelial no-synthase restores migratory capacity of endothelial progenitor cells from patients with coronary artery disease.

Wolf A, Mukherjee J, Guha A. The Warburg effect and tumour cell survival in human GBM.

Wong H. See Howell et al.

Wood G. See Lin et al.

Wu D, Wood K. An analysis of the adaptive immune response towards an embryonic stem cell graft.

Yang PT, Huang L, Jia WW, Skarsgard ED, Sy C. Distribution and expression of transgene green fluorescent protein in mice survived up to four weeks following in utero gene therapy.

Young FBJ, Hayden MR. Regulation of huntingtin palmitoylation and its role in Huntington disease........

You-Ten A. See Lin et al.

Zamponi GR. See Khosravani et al.

Zhang Y. See Khosravani et al.

Zhang Q. See Ward et al. 